\author{
Zdzisław KOCZARSKI \\ https://orcid.org/0000-0003-4977-6160 \\ Instytut Języka Polskiego Polskiej Akademii Nauk
}

\title{
W sporze o Długosza argument nowy: przejątki z Petrarki w Rocznikach Jana Długosza*
}

Zarys treści: Artykuł przedstawia kwestię lektury i wykorzystania dzieł Francesca Petrarki w Rocznikach Jana Długosza. Badanie zostało oparte na komputerowej analizie porównawczej i metodach filologicznych. Omówione zostały rękopisy czytane przez Długosza oraz sposób pozyskiwania przez niego przejątków tekstowych i wplatania ich do kroniki. Przedstawiono również argumenty na poparcie hipotezy o istnieniu kartoteki kronikarza i wyjaśniające metodę jego pracy ze źródłami.

\begin{abstract}
This article shows how Polish chronicler Jan Długosz used the works of Petrarch. The examination is based on computer-assisted comparative analysis as well as on philological methods. The article describes the manuscripts containing Petrarch's works which Długosz had at his disposal, and tries to respond a question when the chronicler (in what periods of his life) got with them in touch. It also analyses Długosz' methods of drawing textual excerpts he inserted into his chronicle. Besides, the arguments supporting hypothesis about the existence of chronicler's special catalogue, in which he might have collected the extracts from various sources, are considered. Finally, his method of the use of sources is characterised in more detail.
\end{abstract}

Słowa kluczowe: Jan Długosz, Roczniki, Francesco Petrarka, przejątek tekstowy, badania korpusowe

Keywords: Jan Długosz, Annals, Francesco Petrarca, textual excerpt, corpus studies

\section{Wstęp}

Szczegółowe badania nad źródłami oraz inspiracjami literackimi Roczników Jana Długosza, podejmowane z sukcesami już w wieku XIX ${ }^{1}$, osiągnęły szczyt zainteresowania historyków i filologów w połowie kolejnego stulecia. Klasyczne już prace Tadeusza Sinki, Jerzego Schnaydera i Władysława Madydy na temat wzorców antycznych wykorzystywanych w kronice ukazały ogromną erudycję i dobre wykształcenie historyka ${ }^{2}$, natomiast rozprawy Anny Rogalanki i Ignacego Zarębskiego poświęcone oczy-

* Publikacja finansowana w ramach programu Ministra Nauki i Szkolnictwa Wyższego - Narodowy Program Rozwoju Humanistyki w latach 2018-2022, nr projektu 0444/NPRH5/H30/84/2017 (Długosz 2.0. Elektroniczny korpus i narzędzia analizy języka Jana Długosza). Zasadnicze tezy niniejszej pracy przedstawiam w artykule The Early Knowledge of Petrarch's Works in Medieval Poland. The Case of Jan Dlugosz, w: VI Ciclo di Studi Medievali. Atti del Convegno, red. R. Dolce, S. Martini, R. Del Monte, Firenze 2020, s. 392-398.

${ }^{1}$ A. Semkowicz, Krytyczny rozbiór „Dziejów Polski” Jana Dlugosza (do roku 1384), Kraków 1887; M. Bobrzyński, S. Smolka, Jan Dtugosz. Jego życie i stanowisko w piśmiennictwie, Kraków 1893.

2 T. Sinko, De Dlugosii praefatione „Historiae Polonorum”, w: Studia z dziejów kultury polskiej, red. H. Barycz, J. Hulewicz, Warszawa 1949, s. 105-145; J. Schnayder, Salustiuszowe echa w „Historii Polski” Dlugosza, „Eos”, 46, 1952, nr 2, s. 141-160; W. Madyda, Wzory klasyczne w „Historii Polski” Dlugosza, „Eos”, 49, 1957/1958, nr 2, s. $177-201$. 
taniu Długosza we współczesnych mu autorach włoskich ${ }^{3}$ udowodniły jego związki z literaturą wczesnego humanizmu. Badania te umożliwily następnemu pokoleniu badaczy podsumowanie stanu wiedzy o pisarstwie Jana Długosza ${ }^{4}$. Początek XXI w. jednak, jak słusznie zauważono w roku Jana Długosza, przynosi konieczność „pogłębienia badań źródłoznawczych dotyczących źródeł wiedzy dziejopisa”.

Spełnieniu tego postulatu może posłużyć projekt „Długosz 2.0”, którego głównym celem jest zastosowanie w pracy z dziełami Długosza nowoczesnych metod językoznawczych: badań korpusowych i stylometrycznych oraz analizy składniowo-semantycznej Roczników ${ }^{6}$. Dzięki takim środkom możliwe będzie nie tylko pogłębienie dotychczas przeprowadzonych badań nad literackimi inspiracjami Długosza, ale także dostarczenie nowych świadectw i obserwacji źródłoznawczych. W niniejszym artykule, przygotowanym w trakcie prac przy projekcie „Długosz 2.0”, wspomniany temat został podjęty z intencją ukazania rzeczywistej skali występowania w Rocznikach przejątków tekstowych z dzieł wybitnego włoskiego przedstawiciela wczesnego humanizmu - Francesca Petrarki.

\section{Stan badań}

Zagadnienie obecności przejątków tekstowych lub ideowych Petrarki w Rocznikach było poruszane kilkukrotnie, ale raczej dość pobieżnie. Poszczególne pomysły badaczy lub ich obserwacje nie spowodowały pogłębionej analizy lub kontynuacji podjętych wątków, przez co niezwykle istotna dla badań nad warsztatem twórczym Długosza lektura humanistyczna nadal pozostaje właściwie nieprzebadana.

Na ideowe podobieństwa przedmowy Roczników z dziełem Petrarki De viris illustribus jako pierwszy zwrócił uwagę T. Sinko ${ }^{7}$ Dzieło to zostało podane przez badacza tylko jako przykład recepcji humanizmu w Polsce, jednak samo umieszczenie nazwisk tych dwóch autorów obok siebie dało asumpt do sprawdzenia tego tropu, zwłaszcza że utwory Petrarki były w późnośredniowiecznej Polsce popularne. Dowiodła tego Nice Contieri w rozprawie o losach recepcji włoskiego poety w Polsce XIV i XV w., w której nazwisko Długosza jako czytelnika tekstów Petrarki jednak się nie pojawia ${ }^{8}$. Konieczność pogłębienia badań N. Contieri postulował I. Zarębski ${ }^{9}$, który wcześniej przeanalizował dzieła polskiego historyka pod względem śladów lektury włoskich humanistów takich jak Boccaccio czy Poggio Bracciolini. Nie znalazł jednak u niego nawiązań do Petrarki ${ }^{10}$.

${ }^{3}$ A. Rogalanka, Przedmowa Dlugosza do „Dziejów Polski”, Rocz. Hist., 19, 1950, s. 68-98. Spośród licznych prac I. Zarębskiego dotyczących humanistycznych zainteresowań Długosza należy tutaj wymienić: tenże, Problemy wczesnego Odrodzenia w Polsce: Grzegorz z Sanoka - Boccaccio - Dlugosz, „Odrodzenie i Reformacja w Polsce”, 2, 1957, s. 5-52; tenże, Dlugosz a Poggio Bracciolini (w sporze o Dlugosza argument), „Rocznik Naukowo-Dydaktyczny. Historia. Wyższa Szkoła Pedagogiczna w Krakowie”, 14, 1962, s. 29-44; tenże, Humanistyczna lektura Dlugosza: Antonio Panormita Beccadelli (w sporze o Dlugosza argument nowy), „Biuletyn Biblioteki Jagiellońskiej”, 17, 1965, s. 5-21. Badania I. Zarębskiego nad De praeclaris mulieribus pogłębił niedawno swoimi obserwacjami W. Olszaniec; tenże, Jan Dlugosz lettore del „De mulieribus claris”, w: Boccaccio e la nuova ars narrandi, red. W. Olszaniec, P. Salwa, Warszawa 2015, s. 137-149.

${ }^{4}$ Zob. M. Plezia, Pisarstwo Jana Dlugosza, „Zeszyty Naukowe Uniwersytetu Jagiellońskiego”, 702, Prace Historyczne, nr 76, 1985, s. 19-30; T. Ulewicz, Historycznoliterackie zaplecze listu dedykacyjnego Dlugosza do Zbigniewa Oleśnickiego, „Zeszyty Naukowe Uniwersytetu Jagiellońskiego”, 702, Prace Historyczne, nr 76, 1985, s. 33-42; U. Borkowska, Historiograficzne poglądy Jana Dlugosza, w: Dlugossiana. Studia historyczne w pięćsetlecie śmierci Jana Dlugosza, cz. 2: Referaty i komunikaty wygłoszone na międzynarodowej sesji w Krakowie w dniach 23 i 24 października 1980 r., red. S. Gawęda, Warszawa-Kraków 1985, s. 19-71.

${ }^{5}$ H. Rajfura, Nowe badania nad życiem i twórczościa Jana Dlugosza. Osiagnięcia i potrzeby, St. Źródł., 56, 2018, s. $193-199$. Artykuł ten jest wartościowym podsumowaniem wydarzeń i dyskusji z roku Jana Długosza.

${ }^{6}$ Szczegółowe informacje o projekcie oraz aktualnym stanie prac są dostępne na stronie: <http://scriptores.pl/dlugosz/> [dostęp: 25.09.2020].

7 T. Sinko, De Dlugosii praefatione, s. 112 n.

${ }^{8}$ N. Contieri, La fortuna del Petrarca in Polonia nei secoli XIV e XV, „Annali dell'Istituto Universitario Orientale. Sezione Slava", 4, 1961, s. 139-166.

${ }^{9}$ I. Zarębski, Iter Italicum - włoska droga wczesnego humanizmu w Polsce, „Rocznik Naukowo-Dydaktyczny. Historia. Wyższa Szkoła Pedagogiczna w Krakowie”, 26, 1967, s. 78 n.

${ }^{10}$ Warto jednak zauważyć, że I. Zarębski trafił na trop inkunabułu z De viris illustribus Petrarki, który Długosz miał nabyć w 1473 r., lecz więcej o nim nie wiadomo; zob. I. Zarębski, Problemy wczesnego Odrodzenia, s. 43, przyp. 59. Wydaje 
Pierwsze dokładniejsze obserwacje na ten temat poczyniła Maria Kowalczyk, która odnalazła marginalia Długosza w rękopisie BJ 444 z Rerum familiarium libri Petrarki ${ }^{11}$. W dalszych badaniach zwróciła również uwagę na możliwe wyzyskanie fraz z jego listów przez Długosza w dokumentach kancelaryjnych w czasie, gdy pełnił on funkcję notariusza Zbigniewa Oleśnickiego ${ }^{12}$. Jej obserwacje jednak, chociaż cenne, dotknęły zagadnienia wykorzystania dzieł włoskiego humanisty jedynie powierzchownie i nie znalazły kontynuacji w pracach kolejnych badaczy przez czterdzieści prawie lat. Wróciła do nich dopiero Hanna Rajfura w rozprawach o pomniejszych dziełach Jana Długosza. Wyróżniła ona dosłowny przejątek z listów Petrarki w przedmowie do Katalogu arcybiskupów gnieźnieńskich oraz wskazała na stylistyczne inspiracje historyka twórczością włoskiego autora, o czym świadczyć może glosa w rękopisie BJ 444 i jej odbicie w Żywocie św. Stanistawa ${ }^{13}$.

Jak wynika z powyższych rozważań, zagadnienie przejątków tekstowych i ideowych z dzieł Petrarki zostało zauważone, lecz nie doczekało się pogłębionej analizy i refleksji. Dobre podsumowanie stanu badań może więc tutaj stanowić nader ogólna uwaga Poli Pauby zawarta w artykule poświęconym obecności różnych poetów i pisarzy w Rocznikach Jana Długosza: „Z utworami Petrarki dziejopis bez wątpienia się zetknął"14.

\section{Cel badań}

Niniejszy artykuł ma stanowić uzupełnienie obserwacji M. Kowalczyk i H. Rajfury o nowy materiał dowodowy w sprawie lektury dzieł Petrarki i zaznaczyć wagę tego zagadnienia dla kwestii humanistycznych elementów w twórczości Jana Długosza. Moim głównym celem jest poszerzenie obserwacji poprzednich badaczy o nowe, dosłowne przejątki tekstowe oraz przedstawienie marginaliów Długosza znalezionych w rękopisach Petrarki ze zbiorów Biblioteki Jagiellońskiej ${ }^{15}$. Wnioski wyciągnięte na podstawie tych obserwacji mają przyczynić się do lepszego poznania stylu historyka i charakteru jego twórczości oraz posłużyć jako kolejny dowód w sprawie jego humanistycznych zainteresowań. Mają również poszerzyć naszą wiedzę na temat tego, w jaki sposób powstawały Roczniki (przede wszystkim zachowany tzw. autograf) oraz jak wyglądała praca Długosza ze źródłami. Badania zostały wykonane za pomocą komputerowej analizy porównawczej oraz metod filologicznych, wykorzystywane są jednak w nich także obserwacje o charakterze kodykologicznym i paleograficznym.

\section{Opis metodologiczny przeprowadzonych badań}

Na początku tekst Roczników został automatycznie oczyszczony ze znaków interpunkcyjnych, a jego grafia uproszczona i ujednolicona $\left(T I^{+ \text {samogt. }} \rightarrow C I^{+ \text {samoglt }} ; A E / O E \rightarrow E ; Y \rightarrow I ; K \rightarrow C\right)^{16}$. Następnie

się, że kronikarz musiał mieć do niego dostęp znacznie wcześniej, ponieważ pojedyncze przejątki z De viris illustribus pojawiają się już w pierwszej redakcji tzw. autografu (zob. rozdz. IV).

11 M. Kowalczyk, Jagiellońskie rękopisy Liwiusza z marginaliami Jana Dlugosza, „Eos”, 58, 1969/1970, nr 2, s. 221.

12 Taż, Z badań nad życiem i biblioteka Mikołaja Kozłowskiego, „Biuletyn Biblioteki Jagiellońskiej”, 22, 1972, s. 21.

${ }^{13}$ H. Rajfura, Jana Dlugosza list dedykacyjny do „,Katalogu arcybiskupów gnieźnieńskich”, „Odrodzenie i Reformacja w Polsce”, 62, 2018, s. 127, przyp. 64; taż, Warsztat pisarski Jana Dlugosza w świetle „Żywotu św. Stanisława”, St. Źródł., 56, 2018, s. 54, przyp. 159.

14 P. Pauba, Poeci i pisarze w „Rocznikach, czyli kronikach sławnego Królestwa Polskiego” Jana Dlugosza. Rekonesans, w: „E fructu arbor cognoscitur”... W sześćsetna rocznicę urodzin Jana Dlugosza, red. K. Krawiec-Złotkowska, T. Ceynowa, Słupsk-Koszalin 2019, s. 162.

${ }^{15}$ Wybór miejsca poszukiwań wynikał z obszerności zbiorów średniowiecznych BJ oraz z prac M. Kowalczyk, które dotyczyły właśnie tego księgozbioru. Należy mieć na uwadze, że badaniu podlegały te rękopisy, które na pewno zawierają dzieła Petrarki. Wśród kodeksów BJ wciąż jednak może być bardzo dużo ekscerptów lub pojedynczych utworów włoskiego humanisty, które czekają na odkrycie (zob. niżej, przyp. 55).

${ }^{16}$ Uwzględniam oczywiście fakt, że grafia nowego wydania Roczników, na którym bazuje analiza (Ioannis Dlugossii Annales seu Cronicae incliti Regni Poloniae, ks. I-XII, Varsaviae-Cracoviae 1964-2005), zachowuje w znacznej mierze oryginalną 
został podzielony na tzw. n-gramy, czyli sekwencje $\mathbf{n}$ wyrazów, gdzie $\mathbf{n}$ należy do zbioru liczb od 2 do $10(\mathbf{n} \in\{2: 10\})$. W wyniku tych działań otrzymano przedstawiony poniżej dla przykładu materiał:

Zdanie wyjściowe: „Reverendissimo in Christo patri, domino Sbigneo de Oleschnicza [...]”:

gdy $\mathrm{n}=2$ : reverendissimo in - in christo - christo patri itd. - otrzymano dwuwyrazowe sekwencje, czyli 2-gramy, $\mathrm{gdy} \mathrm{n}=3$ : reverendissimo in christo - in christo patri - christo patri domino itd. - otrzymano trzywyrazowe sekwencje, czyli 3-gramy,

gdy $\mathrm{n}=4$ : reverendissimo in christo patri - in christo patri domino - christo patri domino sbigneo itd. - otrzymano czterowyrazowe sekwencje, czyli 4-gramy, itd.

W taki sam sposób przetworzono korpus wszystkich łacińskich tekstów Petrarki dostępnych w cyfrowych repozytoriach łacińskojęzycznej literatury włoskiej ${ }^{17}$. Znalazły się w nim następujące dzieła ${ }^{18}$ : Africa, Arringhe, Bucolicum carmen, Carmina varia, Collatio coram Johanne rege, Collatio inter Scipionem, Alexandrum, Hannibalem, Collatio laureationis, De gestis Caesaris, De insigni oboedientia et fide uxoris (s. Historia Griseldis), De otio religioso, De remediis utriusque fortunae, De sui ipsius et multorum ignorantia, De viris illustribus, De vita solitaria, Epistolae extravagantes, Epistolae familiares (s. Rerum familiarium libri), Epistolae metricae, Epistolae seniles ${ }^{19}$, Epistolae sine nomine, Invectiva contra quendam magni status hominem, Invectiva contra cuiusdam anonimi Galli calumniam (s. Contra eum qui maledixit Italiam), Invectiva contra medicum quendam, Itinerarium ad sepulcrum Domini, Orationes, Posteritati, Psalmi poenitentiales (s. Psalmi mei septem), Rerum memorandarum libri, Secretum, Testamentum.

Następnie n-gramy z Roczników zostały automatycznie porównane z odpowiadającymi im n-gramami z poszczególnych dzieł Petrarki, a zatem: 2-gramy z Roczników z 2-gramami z Africa, potem z 2-gramami z Arringhe itd., następnie 3-gramy z Roczników z 3-gramami z Africa, potem z 3-gramami $\mathrm{z}$ Arringhe itd. Wyniki tego procesu, czyli sekwencje powtarzające się w obu porównywanych w danym momencie tekstach, zostały zapisane w osobnych plikach w formacie CSV. N-gramy w nich zebrane posłużyły za materiał badawczy. Chciałbym zaznaczyć, że zastosowany program, którego jestem autorem, dokonywał wyboru sekwencji na wyrazach w konkretnej formie fleksyjnej, a nie leksemach ${ }^{20}$, bo tylko wówczas poszukiwanie dosłownych przejątków z dzieł Petrarki w Rocznikach Jana Długosza, co było moim celem, miało szanse powodzenia.

Inspiracją dla mojego programu był projekt Tesserae (narzędzie do analizy porównawczej intertekstualnych nawiązań w tekstach starożytnych), który działa na korpusie zlematyzowanym (tj. bazującym na leksemach). Tak przygotowany materiał źródłowy poprawia dokładność badania, ale jego stworzenie jest znacznie bardziej czaso- i kosztochłonne, ponadto w pewnym stopniu ogranicza możliwość swobodnego modyfikowania lub rozszerzania korpusu ${ }^{21}$.

pisownię średniowieczną. Uproszczenie grafii tekstu kroniki ma na celu usunięcie ewentualnych pozostałych różnic w zapisie, które mogłyby zmniejszyć precyzję analizy komputerowej.

${ }^{17}$ Pełny korpus jest dostępny pod adresem: $<$ http://www.interbooks.eu/poesia/trecento/francescopetrarca.html>. Większość dzieł jest również dostępna w Corpus Corporum: $<$ http://www.mlat.uzh.ch/MLS/xanfang.php?tabelle=Francesco_Petrarca_cps6> oraz w Letteratura Italiana: <http://petrarca.letteraturaoperaomnia.org/>, gdzie można znaleźć De insigni obedientia et fide uxoris jako osobne dziełko [dostęp do ww. stron: 20.09.2019].

${ }_{18}$ Więcej na temat twórczości Petrarki zob. Petrarch. A Critical Guide to Complete Works, red. V. Kirkham, A. Maggi, Chicago 2009, s. 1-30.

19 Dostępna wersja elektroniczna tego dzieła jest niepełna, moim zdaniem jednak nie miało to większego wpływu na badania - analiza wykonana na posiadanym materiale (15 z 18 ksiąg) nie wykazała żadnych właściwych dla poszukiwań wspólnych sekwencji.

${ }^{20}$ Pod pojęciem „leksem” rozumiem formę słownikową, pod pojęciem „wyraz” - formę gramatyczną. Dla przykładu: pochodzącymi od leksemu „historia” wyrazami są „, historia”, „historiae”, „historiam” itp.; zob. H. Wolanin, Gramatyka opisowa klasycznej łaciny w ujęciu strukturalnym, Kraków 2012, s. 100-103.

${ }^{21}$ Program wykorzystany w moim opracowaniu jest mniej dokładny, ponieważ działa na korpusach niezlematyzowanych, ale pozwala na porównanie tekstu Roczników (lub każdego innego tekstu) z dowolną liczbą innych tekstów i automatyczne wyszczególnienie wszystkich dosłownych przejątków. Program jest w trakcie rozwoju - docelowo może stać się jednym z narzędzi udostępnionych w ramach projektu „Długosz 2.0”. Wszystkie prace przeprowadzono w języku R z użyciem 
Dla potrzeb badań, w zależności od długości n-gramów wyodrębnionych w komputerowej analizie porównawczej poszczególnych par dzieł i stopnia prawdopodobieństwa związków treściowych pomiędzy nimi, dokonano podziału na trzy kategorie n-gramów:

- n-gramy dłuższe - 8-, 9-, 10-gramy, których wzajemny związek treściowy można uznać za niemal pewny,

- n-gramy średnie - 5-, 6-, 7-gramy, których wzajemny związek treściowy można uznać za wysoce lub umiarkowanie prawdopodobny,

- n-gramy krótsze - 2-, 3-, 4-gramy, których wzajemny związek treściowy można uznać za umiarkowanie lub mało prawdopodobny.

Stopień prawdopodobieństwa pochodzenia n-gramu z korpusu porównawczego w Rocznikach jest zależny przede wszystkim od kryterium oryginalności frazy, które przedstawiono $\mathrm{w}$ dalszej części tego rozdziału. W przypadku występowania dwóch lub więcej n-gramów krótszych lub średnich w ich najbliższym otoczeniu (tj. w obrębie jednego zdania lub akapitu) cała grupa była uznawana odpowiednio za n-gram średni lub dłuższy (poz. 29, 43, 46, 52, 54, 58, 59, 65, 70, 71, 74, 78-82 22 ). Warto również zauważyć, że w pojedynczych wypadkach n-gramy zostały uznane za należące do wyższej kategorii także wtedy, gdy w ich najbliższym otoczeniu pojawiły się wyrazy synonimiczne lub zastępcze w stosunku do wyrazów z passusu oryginalnego (poz. 12, 18, 23, 24, 30, 39, 51, 59, 65, 68, 73). W dalszej części artykułu wyżej wymienione przykłady będziemy dla uproszczenia analizować w zmienionych wedle podanych założeń kategoriach.

Zapisane przez komputer wspólne sekwencje wyrazowe zostały poddane szczegółowej, ręcznej analizie filologicznej, mającej na podstawie kilku kryteriów zmniejszyć ryzyko błędnej kwalifikacji n-gramów. Czynnikami generującymi takie ryzyko były: wysoka częstotliwość występowania 2-, 3-, 4-gramów stanowiących powszechne w łacinie każdej epoki grupy syntaktyczne, występowanie danych sekwencji wyrazowych u wcześniejszych autorów (przede wszystkim u Liwiusza ${ }^{23}$ ) oraz powtarzalność cytatów biblijnych i wyrażeń o charakterze formularzowym (liturgicznych lub prawniczych). W związku z tym szczegółowa analiza została poprowadzona według następujących kryteriów - dany n-gram nie był brany pod uwagę, jeżeli:

- występował w Wulgacie (np. illuminat omnem hominem venientem in hunc mundum - J 1,9; zob. Ann. XIIc 446),

- występował u autorów klasycznych (np. in prelio et in fuga - Liwiusz, Ab Urbe condita, XXVII 27, 9; zob. Ann. XIIb 256),

- stanowił formułę prawniczą (np. nec per se nec per [alios], zob. Ann. XIIc 49),

- stanowił formułę liturgiczną (np. Patri et Filio et Spiritui Sancto, zob. Ann. XIIc 447),

- stanowił powszechnie występującą grupę syntaktyczną w łacinie (m.in. wyrażenie przyimkowe [np. ad memoriam], grupę nominalną z przydawką zaimkową [np. studiorum meorum], grupę werbalną [np. cum ita sint] itp. $\left.{ }^{24}\right)$.

dodatkowych pakietów stylo (zestaw narzędzi do analizy stylometrycznej; zob. M. Eder, J. Rybicki, M. Kestemont, Stylometry with R: a Package for Computational Text Analysis, „The R Journal”, 8, 2016, nr 1, s. 107-121, oraz repozytorium pakietu stylo: $<$ https://github.com/computationalstylistics/stylo $>$ ) i magrittr (zestaw narzędzi do poprawiania spójności kodu źródłowego, zob. repozytorium pakietu magrittr $<$ https://github.com/tidyverse/magrittr $>$ ). Więcej o projekcie Tesserae zob. $<$ https://tesserae.caset.buffalo.edu/about.php $>$ oraz N. Coffee i in., The Tesserae Project. Intertextual Analysis of Latin Poetry, „Literary and Linguistic Computing”, 28, 2013, nr 2, s. 221-228 [dostęp do ww. stron: 30.03.2020].

${ }^{22} \mathrm{~W}$ niniejszym artykule zastosowano system odsyłania do tabeli wyników z ponumerowanymi pozycjami zamieszczonymi w aneksie.

${ }^{23}$ Petrarka był miłośnikiem prozy Liwiusza - dość wspomnieć jego słowa z listu adresowanego do starożytnego historyka: „Optarem, si ex alto datum esset, vel me in tuam vel te in nostram etatem incidisse, ut vel etas ipsa vel ego per te melior fierem et visitatorum unus ex numero tuorum, profecto non Romam modo te videndi gratia, sed Indiam ex Galliis aut Hispania petiturus"; Epistolae familiares XXIV 8, 1. Do samego Petrarki należał również jeden z rękopisów Ab Urbe condita (rkps BJ 522), z którego korzystał Jan Długosz; zob. Catalogus codicum manuscriptorum medii aevi Latinorum qui in Bibliotheca Jagellonica Cracoviae asservantur, t. 3, red. M. Kowalczyk i in., Wratislaviae 1984, s. 250.

${ }^{24}$ W kwestii szczegółowego rozumienia grup syntaktycznych zob. M. Kaczmarkowski, Nominalne grupy syntaktyczne łaciny okresu klasycznego, Lublin 1985, s. 92 n. 
Testem powszechności występowania danego n-gramu była jego wyraźna obecność w Corpus Corporum $^{25}$, zawierającym 160 mln wyrazów (stan na wrzesień 2019 r.). Znajdują się tam dzieła większości autorów klasycznych i kościelnych, których teksty stanowiły podstawę średniowiecznego kształcenia. W wypadku negatywnego wyniku testu, a zatem występowania danej sekwencji tylko w dziełach Petrarki (lub autorów późniejszych, którzy mogli korzystać z jego dzieł), n-gram był „odsyłany” na listę wyników przeznaczonych do dalszych badań ${ }^{26}$.

W tym miejscu wypada również zastrzec, że w trakcie przeglądu tak obfitego materiału badawczego mogło dojść do przeoczenia pojedynczych najkrótszych sekwencji, tj. 2-, 3-gramów, jednak, jak się wydaje, nie powinno to mieć istotnego wpływu na ostateczne wyniki badań.

\section{Analiza materiału badawczego}

\section{Ilościowa analiza materiału badawczego}

Analiza materiału badawczego wykazała łącznie 84 wspólne dla obu tekstów sekwencje wyrazowe, które można uznać za bezpośrednie przejątki Długosza z Petrarki. Należą do nich zarówno n-gramy dłuższe (20 przykładów) i średnie (14 przykładów), jak i - a może przede wszystkim - n-gramy krótsze (50 przykładów).

Pochodzą one z pięciu dzieł Petrarki (kolejność według liczby przykładów):

Epistolae familiares

De viris illustribus

De remediis utriusque fortunae

Epistolae sine nomine

Posteritati
(52 n-gramów, w tym: 14 dłuższych, 10 średnich, 28 krótszych), (14 n-gramów, w tym: 1 dłuższy, 2 średnie, 11 krótszych), (13 n-gramów, w tym: 2 dłuższe, 1 średni, 10 krótszych), (3 n-gramy, w tym: 2 dhuższe, 1 średni).

(2 n-gramy, w tym: 1 dłuższy, 1 krótszy).

Największa liczba przejątków pochodzi z Epistolae familiares, będącego jednocześnie najdłuższym dziełem w korpusie Petrarki. Razem z Epistolae sine nomine oraz listem autobiograficznym Posteritati stanowią one, jako twórczość epistolograficzna, największą grupę gatunkową dzieł, z których korzystał Długosz - może to być też istotna wskazówka dla analizy zainteresowań literackich historyka oraz dla poszukiwania rękopisów, do których miał dostęp. Jak już wspomniano we wstępie, w jego posiadaniu był na pewno kodeks z ks. XII-XXIV zbioru Epistolae familiares. W wypadku dzieł nieepistolarnych dysponujemy natomiast kilkoma kodeksami z tekstem De remediis utriusque fortunae, które w czasach Długosza znajdowały się na terenie Polski ${ }^{27}$. Do jednego z nich Długosz miał dostęp bezpośredni, o czym świadczą znalezione w rękopisie marginalia historyka (zob. rozdz. III/2/a). Nie udało się jednak odpowiedzieć dotychczas na pytanie, z których kodeksów na pewno korzystał on podczas lektury De viris illustribus i pozostałych listów Petrarki, i czy w ogóle przetrwały one do naszych czasów (choć, jak już wspomniano wcześniej, I. Zarębski sugerował istnienie konkretnego inkunabułu z De viris illustribus). Być może niniejszy artykuł stanie się przyczynkiem do szerzej zakrojonych badań kodykologicznych w tej kwestii.

Opisany powyżej rozkład ilościowy przejątków różnej długości można przedstawić również zbiorczo na wykresie kołowym (zob. wykres 1).

${ }^{25}$ Korpus dostępny pod adresem: <http://www.mlat.uzh.ch/MLS/>. Szczegółowe informacje o projekcie: Ph. Roelli, The Corpus Corporum, a New Open Latin Text Repository and Tool, „Archivum Latinitatis Medii Aevi”, 72, 2014, s. $289-304$.

${ }^{26}$ Należy mieć na uwadze, że negatywny wynik testu powszechności nie zakładał automatycznego kwalifikowania danego n-gramu do dalszych prac. Ostateczna decyzja w tej sprawie wynikała każdorazowo z analizy kontekstowej i semantycznej badanych sekwencji.

27 Są to rękopisy: BJ 721, BJ 722, BJ 724, BJ 725; zob. Catalogus codicum manuscriptorum medii aevi Latinorum qui in Bibliotheca Jagellonica Cracoviae asservantur, t. 5, red. M. Kowalczyk i in., Wratislaviae 1993, s. 182-204. 


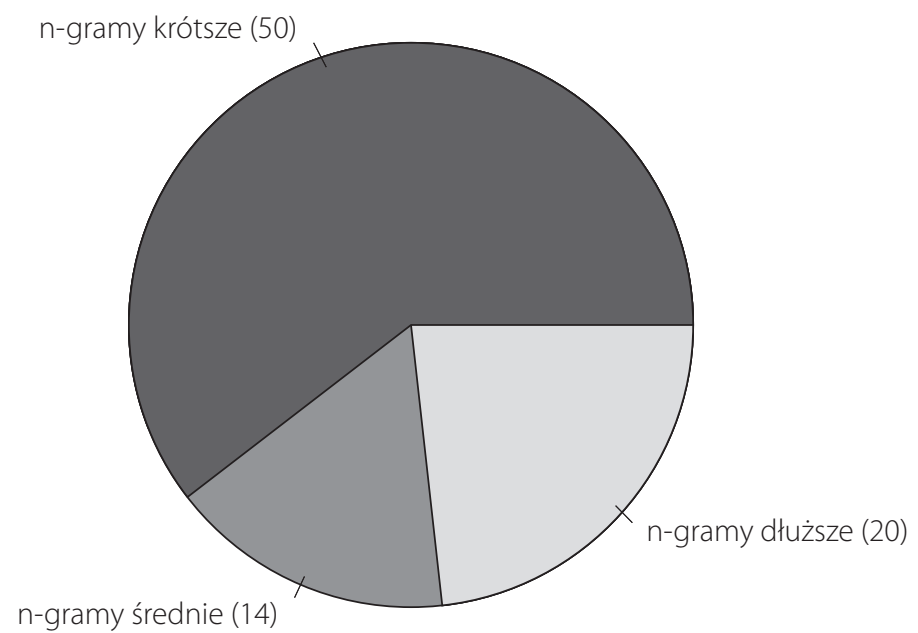

Wykres 1. Rozkład ilościowy przejątków z dzieł Petrarki w Rocznikach Jana Długosza w zależności od ich długości

Widać tutaj wyraźnie, że najwięcej przejątków to krótsze sekwencje (2-, 3-, 4-wyrazowe), których prawdopodobieństwo pochodzenia właśnie z dzieł Petrarki jest dość niskie. Należy jednak mieć na uwadze, że analiza wykazała także istnienie stosunkowo dużej liczby 8-, 9-, 10-gramów - stanowią one prawie $25 \%$ wszystkich jej wyników. Można więc założyć, że wykorzystanie dłuższych sekwencji z pojedynczych dzieł Petrarki zwiększa prawdopodobieństwo pochodzenia stamtąd krótszych i średnich n-gramów, i tym samym uprawomocnia ich przynależność do materiału badawczego.

Wysoka liczba najkrótszych cytatów nie powinna zresztą zaskakiwać - krótkie, kilkuwyrazowe frazy wchodzą do naszego zasobu leksykalnego najłatwiej i - bardzo często - nieświadomie. Może to tłumaczyć, dlaczego tak wiele przejętych n-gramów nie ma swojego oznaczenia w zachowanych rękopisach w postaci znaku mnemotechnicznego. Z tego względu należy również domniemywać, że Długoszowa lektura dzieł Petrarki była wnikliwa i mogła mieć jakiś wpływ na idiolekt kronikarza ${ }^{28}$.

\section{Jakościowa analiza materiału badawczego}

W tym rozdziale szczegółowej analizie poddano przejątki z poszczególnych dzieł Petrarki (przedstawianych w kolejności alfabetycznej). Badanie to jest niezbędne dla zrozumienia zasady korzystania z nich przez Długosza oraz dla poznania powodu jego zainteresowania nimi, jak i - w szerszym sensie - zagadnienia pracy historyka ze źródłami humanistycznymi w ogóle. W miarę możliwości analizie poddawano również rękopisy dzieł Petrarki, o których wiadomo, że Długosz na pewno z nich korzystał. Powinno to pozwolić na wyciągnięcie wniosków na temat czasu, w którym mógł się z nimi zetknąć, jak również stopnia ich wyzyskania przez kronikarza. Ze względu na rozmiar artykułu ograniczę się jedynie do najważniejszych obserwacji i wniosków. Szczegółowa lista wyników została udostępniona w formie aneksu na końcu artykułu.

\section{a) De remediis utriusque fortunae (Lekarstwa na dobry $i$ zhy los)}

Pierwszym z analizowanych dzieł Petrarki jest De remediis utriusque fortunae, stanowiące przedstawienie wewnętrznego dialogu Rozumu z różnymi emocjami, których człowiek może doznać, zarówno w sytuacjach pomyślnych: Radość i Nadzieja (ks. I), jak i niepomyślnych: Cierpienie, Lęk i Pragnienie (ks. II). Rozum podejmuje się trudnej próby temperowania tych uczuć oraz podsuwania rozwiązań, dzięki którym człowiek może osiągnąć cnotę umiarkowania. Stoickie rozważania Petrarki szybko

${ }^{28}$ Pod pojęciem ,idiolekt” rozumiem ,język pojedynczego użytkownika w danym okresie rozwoju tego użytkownika”; zob. K. Polański, Idiolekt, w: Encyklopedia językoznawstwa ogólnego, red. K. Polański i in., Wrocław 1999, s. 243. 
znalazły uznanie w całej Europie, o czym świadczy ogromna liczba odpisów dzieła jeszcze z końca XIV w. ${ }^{29}$ Popularność zyskało ono także w Polsce, zwłaszcza wśród krakowskich protohumanistów ${ }^{30}$.

W zbiorach Biblioteki Jagiellońskiej znajdują się cztery rękopisy De remediis utriusque fortunae: BJ 721, BJ 722, BJ 724, BJ 725. Przegląd ich zawartości pozwolił mi odnaleźć marginalia Długosza w pierwszym z wymienionych, tj. BJ 721. Jest to kodeks pergaminowy z XIV w., składający się ze 186 kart. Tekst główny jest pisany humanistyczną minuskułą przez jednego skrybę, podpisanego na końcu rękopisu: „Ego Iacobus Nicolai missnensis dioc[esis] s[cripsi]” (zob. rkps BJ 721, k. 187v). Na podstawie zdobień inicjałów i charakteru pisma badacze postulują włoskie, być może padewskie, pochodzenie rękopisu. Przemawiają za nim również „włoskie” glosy, m.in. „Arecium” i „Florencia” przy passusach odnoszących się do tych miast (zob. rkps BJ 721, k. 135v i 137r) ${ }^{31}$. Trudno jednak określić jednoznacznie, kim jest rzeczony skryba - powszechnie akceptuje się więc hipotezę o bliżej nieznanym Jakubie, synu Mikołaja z Miśni32 ${ }^{32}$

Bez względu na rzeczywistego autora rękopisu możemy podać przypuszczalny terminus post quem jego powstania: 1366 r., a więc powstanie ostatecznej wersji dzieła Petrarki. W tekście nie ma bowiem jednoznacznych dowodów na to, że mamy do czynienia z pierwszą, nieprzerobioną wersją tekstu ${ }^{33}$. Jest to prawdopodobnie bezpośredni lub jeden z bliższych oryginałowi odpisów, choć potwierdzić to mogłyby jedynie dokładne badania krytyczne nad tekstem De remediis utriusque fortunae.

Sam rękopis, poza pozbawionym początku tekstem głównym i pisanymi tą samą ręką glosami, zawiera liczne inne marginalia: różne rodzaje znaków mnemotechnicznych, w tym co najmniej cztery typy „rączek” - manikuł, rozmaite glosy kilku autorów, a także krótkie komentarze. Istotne dla niniejszych rozważań marginalia Długosza ${ }^{34}$ są rozsiane w stosunkowo niewielkiej liczbie w różnych miejscach rękopisu: glosy przede wszystkim w obrębie pierwszej księgi, natomiast manikuły w obrębie drugiej (zob. tab. 1 i 2).

Dwadzieścia trzy adnotacje zostawione przez Długosza na marginesie pokazują zapewne, co było dla niego szczególnie interesujące - dotyczą one sławnych postaci antyku (Cyceron, Katon), przedstawiają typy ludzkich zachowań (opinie prostego ludu, żądza starych kobiet) lub odnoszą się do literatury (cechy słabych pisarzy, słowa Platona). Warto zauważyć, że niektóre z uwag znajdują się przy rączkach obcego autorstwa (nr 6,9,12,13,14). Niestety nie udało mi się odnaleźć nawiązań do tych glos w Rocznikach - stanowiły one zapewne raczej pomoc w lekturze dzieła niż gotowe treści przeznaczone do wplatania w tekst kroniki.

Tymczasem siedem znalezionych przeze mnie manikuł Długosza ma odniesienie w postaci przejątku, który oznaczają w tekście. Wszystkie poza jedną reprezentują identyczny wariant graficzny. Wyróżniają się zawsze tą samą, charakterystyczną formą i położeniem: jest to zaciśnięta w pięść dłoń z wyprostowanym palcem wskazującym i szeroki mankiet pod nią, umieszczone po lewej stronie kolumny, ledwie kilka milimetrów od tekstu. Dodajmy, że tożsame manikuły można odnaleźć w wielu innych rękopisach, do których Długosz miał dostęp (m.in. BJ 514, BJ 523, BJ 121035). Odmienna rączka z k. 154r różni

${ }^{29}$ N. Mann, The Manuscripts of Petrarch's „De remediis”. A Checklist, „Italia Medioevale e Umanistica”, 14, 1971, s. 57-90.

30 J. Domański, Scholastyka i poczatki humanizmu w myśli polskiej XV wieku, Warszawa 2011, s. 78 n., 86-91.

${ }_{31}$ Autor rękopisu pozostawił po sobie liczne glosy: poprawki do tekstu głównego, wskazania cytatów z Księgi Hioba, znaki mnemotechniczne „No[ta]” i oznaczenia ważnych partii narracyjnych „Istoria”. W pojedynczych miejscach występują także wskazania tematu passusu: wspomniane już „Arecium” i „Florencia” przy opisie tych miast, „Insula” przy opisie wyspy Taprobane (k. 141r) oraz „Istoria estensis” przy anegdocie o dziecku z nieprawego łoża (k. 124r). Wyraźnie pokazują one zainteresowania autora zagadnieniami włoskimi oraz kosmografią. Warto również zauważyć glossę „Velus aureum” (k. 86r), która wskazuje na znajomość mitu o złotym runie.

32 Więcej na temat opisywanego kodeksu: Catalogus codicum, t. 5, s. 183 n.; N. Contieri, La fortuna del Petrarca in Polonia, s. 157; N. Mann, The Manuscripts of Petrarch's „De remediis”, s. 66.

${ }_{33}$ T. Kircher, On the Two Faces of Fortune (,De remediis utriusque fortunae”), w: Petrarch. A Critical Guide, s. 245.

${ }^{34}$ Na możliwe pochodzenie niektórych manikuł od Długosza wskazywała już M. Kowalczyk, jednak nie wyraziła w tej sprawie decydującego sądu; zob. Catalogus codicum, t. 5, s. 183.

35 Potwierdzałoby to zatem przypuszczenie o pochodzeniu tego typu manikuły spod pióra Długosza, na co zresztą wskazywano już wcześniej; zob. M. Kowalczyk, Marginalia Jana Dlugosza na rękopisie BJ 1210 „De civitate Dei” św. Augustyna, „Biuletyn Biblioteki Jagiellońskiej”, 18, 1966, nr 2, s. 64; taż, Jagiellońskie rękopisy Liwiusza, s. 225-228. 
się od właściwych znaków mnemotechnicznych historyka (mankiet znajduje się z boku pięści, a palec wskazujący jest zakrzywiony), ale ponieważ wskazuje wyraźnie jeden z przejętych cytatów, znalazła się w poniższym wykazie ${ }^{36}$.

Tabela 1. Glosy Długosza w rękopisie BJ $721^{37}$

\begin{tabular}{|c|c|c|c|}
\hline Lp. & Marginale Dlugosza & Lokalizacja & Passus De remediis utriusque fortunae Petrarki \\
\hline 1. & de vulgi opinionibus & $10 \mathrm{v}$ & „Dixi et - stultum est” (I 11) \\
\hline 2. & de vulgi iudicio & $11 \mathrm{r}$ & „Vulgus insanos - falsis habeat” (I 12) \\
\hline 3. & $\begin{array}{c}\text { de litterarum superscriptionibus et [iudiciis?] } \\
\text { alternatis }\end{array}$ & $11 \mathrm{r}$ & „Ad famam - fieri volunt” (I 12) \\
\hline 4. & de [tractu?] promotis & $11 \mathrm{v}$ & „Hec de - numerat sapientum!” (I 12) \\
\hline 5. & patria a viro, non vir a patria fulgit & $13 \mathrm{v}$ & „Est que - laus erit” (I 15) \\
\hline 6. & quid Plato scribit* & $13 \mathrm{v}$ & „Ut enim - atque instrui” (I 15) \\
\hline 7. & de aurea etate & $17 \mathrm{r}$ & „Quanto fuit - gaudet avis” (I 18) \\
\hline 8. & Stacius & $22 \mathrm{v}$ & „Antiqui et - pompa placet” (I 23) \\
\hline 9. & Nero* & $23 r$ & „Ad vos - dictu est” (I 23) \\
\hline 10. & auctoris imitatio non omnibus tuta est* & $24 \mathrm{r}$ & „Exemplo libentius - imitantur effingunt” (I 24) \\
\hline 11. & nota dignum & $36 \mathrm{v}$ & „Nam quis - vera esset” (I 38) \\
\hline 12. & Nero* & $37 \mathrm{v}$ & „Itaque Neronem - propria collisisse” (I 38) \\
\hline 13. & de Nerone* & $38 \mathrm{r}$ & „In uno - carmine edito” (I 38) \\
\hline 14. & nota de vulgo* & $40 \mathrm{v}$ & „Non parcit - libertate utitur” (I 42) \\
\hline 15. & de scriptoribus malis & $42 \mathrm{r}$ & „Illi equidem - discretio est” (I 43) \\
\hline 16. & primus Cato agriculture precepta dat & $52 \mathrm{v}$ & „Primus quidem - non improbo” (I 57) \\
\hline 17. & de morte Ciceronis & $53 \mathrm{v}$ & „Quis non - est Cicero” (I 58) \\
\hline 18. & Hortensius primus pavonem occidit rome & $55 \mathrm{r}$ & „Ita vestram - occidisse fertur” (I 62) \\
\hline 19. & de Gula & $56 \mathrm{v}$ & „Gule quidem - et mors” (I 64) \\
\hline 20. & Aristippus & $95 \mathrm{v}$ & „Legisti ut - hominum vestigia” (II 9) \\
\hline 21. & vetule plus estuant & $105 \mathrm{r}$ & „Ardor nempe - violentius estuat” (II 18) \\
\hline 22. & Monstrum est superbus homuncio & $166 \mathrm{r}$ & „Nota sunt - superbus homuncio” (II 111) \\
\hline 23. & ait attende pulvis pessime & $178 v$ & „Sed violenta - an frangatur” (II 121) \\
\hline
\end{tabular}

Tabela 2. Manikuły Długosza w rękopisie BJ 721

\begin{tabular}{|c|c|c|c|c|}
\hline Lp. & $\begin{array}{c}\text { Marginale } \\
\text { Długosza }\end{array}$ & Lokalizacja & $\begin{array}{c}\text { Passus De remediis utriusque } \\
\text { fortunae } \text { Petrarki }\end{array}$ & Passus Annales Długosza \\
\hline 1. & manikuła & $53 \mathrm{v}$ & $\begin{array}{c}\text { „Spaciabatur illis - circumspecione } \\
\text { periculi” (I 58) }\end{array}$ & $\begin{array}{l}\text { "Talisque tunc - nulla restituent” } \\
\text { (XIIb 227) }\end{array}$ \\
\hline 2. & manikuła & $102 \mathrm{r}$ & $\begin{array}{c}\text { "Sepe illum - vita exigit" } \\
\text { (II 13) }\end{array}$ & $\begin{array}{c}\text { "Afferebantur insuper - egestatem recidebat" } \\
\text { (Xa 58) }\end{array}$ \\
\hline 3. & manikuła & $124 \mathrm{v}$ & „Nunc fabellam - casta fui” (II 50) & „Rursus Keystuhus - cunctandum, fili!” (Xa 95) \\
\hline 4. & manikuła & $141 \mathrm{r}$ & „Legisti ut - et filium” (II 78) & „Sancta et - non corrupissent” (XIb 32) \\
\hline 5. & manikuła & $151 \mathrm{r}$ & „Nilus se - voluptate percipias” (II 90) & „Vix pontificem - et adversa” (XIIb 43) \\
\hline 6. & manikuła $^{38}$ & $154 \mathrm{r}$ & „Et confestim - ait Flaccus” (II 91) & „Terre motuum - muscas evadunt” (I 72) \\
\hline 7. & manikuła & $159 \mathrm{r}$ & „Ut Iohannes - qui vincebant” (II 96) & „Dux exercitus - fugere cepit” (XIIb 75) \\
\hline
\end{tabular}

\footnotetext{
36 Wypada zauważyć, że manikuła z k. 154r miała prawdopodobnie swoją bliźniaczkę na k. 159r, jednak ta została nieumiejętnie wymazana lub zatarła się. Obecnie w tym samym miejscu stoi „właściwa” manikuła Długosza.

37 Asteryskiem oznaczono glosy, przy których stoją manikuły różniące się od Długoszowych.

${ }^{38}$ Manikuła różni się od pozostałych.
} 
Opisane wyżej obserwacje pozwalają założyć, że kronikarz bacznie zwracał uwagę na (prawdopodobnie $^{39}$ ) wcześniej postawione znaki mnemotechniczne, a w wypadku zainteresowania wskazywanymi przez nie treściami opatrywał je własnymi glosami. W podobny sposób można by wytłumaczyć wykorzystanie cytatu wskazanego przez różniącą się od pozostałych manikułę z k. 154r, o ile nie jest ona jakimś odległym wariantem znaku Długosza. Wszystko to mogłoby więc stanowić dowód dokładnej lektury danego dzieła przez historyka i odwoływania się przez niego do obserwacji poprzednich czytelników rękopisu.

O dosyć dobrej i wnikliwej znajomości przez kronikarza pracy De remediis utriusque fortunae świadczy natomiast przejmowanie przez niego treści oznaczonych manikułami. Trzy z takich przejątków znalazły się już w I redakcji tzw. autografu (poz. 3, 7, 9), co dowodzi wczesnego dostępu autora do kodeksu, a pochodząca z najpóźniejszego okresu prac (z IV redakcji, zob. rozdz. IV) nad Rocznikami pojedyncza sekwencja (poz. 12) może być dowodem korzystania z rękopisu przez historyka nawet w ostatnich latach życia. Dziwić może jednak zupełny brak cytatów z tego dzieła w II redakcji - być może w czasie prac nad nią Długosz nie miał dostępu do kodeksu BJ 721? Mogłoby to również tłumaczyć znacznie mniejszą liczbę manikuł niż w rękopisie BJ 444 (zob. rozdz. III/2/b).

Oznaczone passusy Długosz wykorzystuje w dwojaki sposób. Po pierwsze, sięga po całe sekwencje wyrazowe, wplatając je w odpowiednim miejscu dzieła. Charakteryzując pośmiertnie Zbigniewa Oleśnickiego, Długosz stosuje słowa: „Talis [vir est ablatus] qualem, ut auguror, secula nulla restituent”40 (poz. 5). Podsumowując wybór Andrzeja Łaskarza z Gosławic na biskupstwo poznańskie, sięga po paremiczną sentencję o świętości elekcji: „Sancta et felix eleccio, que utinam [per omnes regiones et etates continuaretur] atque malis peiores et peioribus pessimi succedentes orbem terrarum tradita per manus nequicia ac superbia non corrupissent" (poz. 10). Co ciekawe, owa złota myśl staje się także podstawą dla kunsztownej wypowiedzi Długosza złożonej z wyrażeń biblijnych oraz zakończonej cytatem z Jana z Salisbury: ,pestilenciam etenim, famem, concussiones gencium, collisiones regnorum et quam plurima adversa terris provenire ex eo, quod honores ecclesiastici ad precium et humanam graciam personis immeritis conferuntur" ${ }^{41}$. Rzeczona sentencja jest najdłuższym wspólnym dla Długosza i Petrarki n-gramem znalezionym w całym przebadanym materiale.

Po drugie, Długosz wykorzystuje pojawiające się w zaznaczonych miejscach oryginalnie brzmiące frazy, wpisując je w podobne co do kontekstu partie tekstu. W ten sposób może łatwiej wypowiedzieć się na interesujące go tematy, np.: bogactwa (poz. 7: „vasa argentea divesque supellex”), stosowności zachowania (poz. 9: „,non est - inquit - amplius [cunctandum, fili]”), trzęsień ziemi (poz. 12, ,usque ad ruinam [et internicionem] civitatum et vicorum”), bitwy (poz. 13: „omne robur exercitus”). Jedną krótszą sekwencję wykorzystał także bez kontekstu jako ramę wypowiedzi (poz. 11: „vix [pontificem] invenies, cui [plura contigerunt secunda et adversa]"), choć w tym wypadku manikuła stoi w tekście nieco wcześniej (nie zdołałem znaleźć odniesienia do oznaczonego passusu w Rocznikach).

Poza korzystaniem z zaznaczonych passusów polski historiograf wplatał do dzieła także pojedyncze frazy, które - być może nieświadomie - zwróciły jego uwagę podczas lektury De remediis utriusque fortunae (poz. 1-4, 6, 8, m.in. „blando murmure”, „occasionem ulcionis omittere”). W tym miejscu należy zauważyć, że nie sposób ocenić skali rzeczywistego wpływu dzieła włoskiego autora na język i styl Długosza - pojedyncze marginalia oraz przejątki, które zostały opisane powyżej, są jedynie świadectwem lektury De remediis utriusque fortunae. Trudno na ich tylko podstawie wnioskować o predylekcjach

\footnotetext{
39 Bez dokładnych badań kodykologicznych nie ma możliwości jednoznacznego wskazania, co pojawiło się na poszczególnych kartach jako pierwsze - glosa Długosza czy obca manikuła. Osobiście przyjmuję założenie, że to Długosz komentuje postawione wcześniej znaki. Na marginesie tych rozważań warto odnotować potrzebę stworzenia swego rodzaju katalogu znaków mnemotechnicznych znajdujących się w kodeksach średniowiecznych i ich możliwych autorów. Takie narzędzie mogłoby w pewnym stopniu poprawić nasz stan wiedzy na temat recepcji i transmisji rękopisów w dawnej Polsce.

${ }^{40}$ Nawiasem kwadratowym w cytatach oznaczono fragmenty wypowiedzi, które nie stanowią części przejątków, a są istotne dla kontekstu wypowiedzi.

41 Zob. Johanni Saresberiensis Polycraticus, VII 20, wyd. Migne PL, t. 199, Parisiis 1855, s. 689D.
} 
leksykalnych, gramatycznych czy stylistycznych autora. Na wysnucie takich wniosków i ewentualne odkrycie rzeczonych wpływów dzieł Petrarki pozwoliłyby tylko dokładniejsze badania stylometryczne, wykraczające jednak znacząco poza zakres niniejszego artykułu.

\section{b) De viris illustribus (O sławnych mężach)}

Kolejnym dziełem Petrarki, z którego korzystał Długosz, były dwie księgi biografii sławnych postaci starożytnych pt. De viris illustribus. Materiał do pracy włoski humanista czerpał bezpośrednio z historyków rzymskich (przede wszystkim z Liwiusza), ponadto z mitologii oraz Biblii. W pierwszej księdze pojawiają się postaci z historii Rzymu, w drugiej natomiast postaci mitologiczne i starotestamentowe ${ }^{42}$. Nie udało się dotąd odnaleźć kopii dzieła, którą mógł dysponować polski historyk, ale możliwość posiadania przez niego biografii starożytnych w formie inkunabułu sugerował swego czasu I. Zarębski ${ }^{43}$.

Samych przejątków z dzieła jest u Długosza stosunkowo niewiele: jedenaście krótszych, dwa średnie $i$ jeden dłuższy. Tak duże nagromadzenie krótszych cytatów, przy braku materiału kontrolnego w postaci rękopisu, może budzić uzasadnione wątpliwości, czy rzeczone frazy na pewno stanowią bezpośrednie przejątki z dzieła Petrarki. Średnie i dłuższe sekwencje natomiast są nieliczne i niezbyt wyróżniające się - stanowią one częściej element ramy wypowiedzi niż charakterystyki postaci. Pomimo to wszystkie wybrane n-gramy przeszły pomyślnie test powszechności, czyli nie pojawiały się u wcześniejszych od Petrarki autorów w Corpus Corporum. Dlatego właśnie należy przyjrzeć się im bliżej. Być może szczegółowa analiza pozwoli uprawomocnić ich obecność w materiale badawczym.

Widać, że zgodnie ze swoimi zamiłowaniami Długosz wykorzystał trzy krótsze sekwencje przy okazji opisu postaci (poz. 19: ,iactanciam secum ducebat”, 22: „post contractam affinitatem”, 26: „,nullatenus negligendum ratus") oraz w partiach tekstu związanych z przedstawianiem działań wojennych (poz. 16, 17, 20, 27, m.in. „equo calcaribus adacto [contorquens]”, „ad infaustum bellum descendisse”). Służą one odpowiednio pogłębieniu charakterystyki bohaterów lub intensyfikacji scen batalistycznych. Wszystkie pozostałe cytaty polski historyk wykorzystuje jako ramy wypowiedzi. Dzięki nim może opowiedzieć o zamierzeniach i działaniach postaci (poz. 14, 15, 18, 21, 23, m.in. „[hiis] verbis increpitum [liberalissime] tamen [muneratum]”, ,a proposito belli [prosequendi revocent et] omni persuasione") czy poczynić dygresję o niedostatku źródeł historycznych (poz. 24: „[in perpetuam oblivionem venere, ita] ut illorum nomen obscurum [prorsus sit] et obsoletum"). Najdłuższy z analizowanych n-gramów (poz. 25: „,non a fronte sed a tergo, [nullam custodiam illic] consistere [rati], Cruciferis [apcior] videbatur”) również funkcjonuje jako rama wypowiedzi, dając Długoszowi możliwość przedstawienia zachowania Krzyżaków w trakcie oblężenia.

Jak zatem widać, chociaż w wypadku De viris illustribus nie dysponujemy właściwą podstawą rękopiśmienną, potwierdzającą, że Długosz miał dostęp do tego dzieła, analizowane n-gramy zdają się jednak wykorzystywane zgodnie z opisanymi już wcześniej prawidłami warsztatu literackiego historyka. Długosz musiał więc mieć dostęp do dzieła Petrarki. Była to wszakże najprawdopodobniej lektura pobieżna, o czym świadczy niewielka liczba i długość sekwencji. Nie wiadomo również, czy kronikarz w ogóle posiadał to dzieło w swojej biblioteczce, czy jedynie korzystał z jakichś ekscerptów.

\section{c) Epistolae familiares $=$ Rerum familiarium libri (Listy do przyjaciót $)$}

Kolejnym dziełem Petrarki, z którego korzystał Jan Długosz, są Epistolae familiares. Jest to literacka korespondencja włoskiego humanisty z przyjaciółmi i możnymi XIV w. oraz - w ostatniej księdze - z autorami starożytnymi. Obejmuje ona 350 listów, pisanych od 1325 do 1366 r. Wzorem dla Petrarki były utwory Cycerona i Seneki. Tematyka dzieła jest niezwykle różnorodna - począwszy od wątków autobiograficznych i podróżniczych, poprzez bieżące wydarzenia i kwestie związane z życiem oraz doświadczeniami adresatów, aż po szeroko pojęte zagadnienia społeczne, polityczne, filozoficzne

${ }^{42}$ R.G. Witt, The Rebirth of the Romans as Models of Character (,De viris illustribus”), w: Petrarch. A Critical Guide, s. 109.

43 I. Zarębski, Problemy wczesnego Odrodzenia, s. 43, przyp. 59. 
i etyczne. Gruntownie przemyślana kompozycja dzieła i kunsztowna stylistyka przyniosły mu popularność oraz uznanie w oczach potomnych ${ }^{44}$.

W Bibliotece Jagiellońskiej zachował się jeden kodeks z listami Petrarki, a dokładniej ich drugą połową, czyli ks. XII-XXIV. Jest to papierowy kodeks BJ 444, spisany przed 1435 r. przez Konrada Hufzwanga w Bazylei lub Padwie. Oprócz korespondencji włoskiego humanisty zawiera także pojedyncze listy papieża Leona Wielkiego oraz św. Hieronima. Właścicielem tomu był pierwotnie Mikołaj Kozłowski, który najprawdopodobniej zakupił go w trakcie podróży do Włoch. Po jego śmierci natomiast kodeks został zapisany w testamencie bibliotece, ale trafił w ręce Długosza na bliżej nieokreślony $\mathrm{czas}^{45}$.

Długosz jest autorem największej liczby znajdujących się w nim glos w postaci notatek oraz poprawek do tekstu głównego. Doliczyć do tego należy aż 536 (!) manikuł jego autorstwa rozsianych po całym tekście listów, z których 24 wskazują późniejsze bezpośrednie przejątki w Rocznikach (a więc jedynie niecałe 5\% wszystkich manikuł oznacza sekwencje, które historyk faktycznie wplótł do dzieła ${ }^{46}$ ). Ze względu na ogromną liczbę emendacji i manikuł pisanych ręką Długosza, nie wspominając już o dziesiątkach innych linii, podkreśleń i pomniejszych jego zaznaczeń, nie jest możliwe zestawienie ich wszystkich w formie tabeli - te, które rzeczywiście wskazują lokalizację cytatów, zostały odnotowane w aneksie. Warto jednak przyjrzeć się bliżej glosom Długosza, których razem jest 26. Podsumowują one tematykę interesujących historyka passusów i tłumaczą niejasne partie tekstu. Ich zbiorcze zestawienie znajduje się poniżej (zob. tab. 3).

Marginalne notatki przedstawiają szeroki zakres zainteresowań historyka, np. opisy geograficzne (Jerozolima, Kreta), przedstawienia sławnych postaci (Cyceron, Katylina), kwestie literackie (liczba listów Petrarki, stylistyka). Niektóre z glosowanych miejsc znajdują odzwierciedlenie w tekście Roczników. Można tam bowiem odnaleźć m.in. porównanie Popiela do Sardanapala, ostatniego króla Asyrii (zob. Ann. I 155) czy wzmiankę o sławie Solona jako prawodawcy (zob. Ann. IX 247), która zdaje się właśnie świadectwem czytania listów Petrarki. Częściej jednak autorskie adnotacje stanowią jedynie pomoc w lekturze i nie mają bezpośrednich odniesień w kronice.

Podobnie przedstawia się kwestia manikuł. Jedynie 24 znaki mnemotechniczne dokładnie wskazują lokalizację przejątków, choć należy zauważyć, że dwie trzecie z nich odnoszą się do średnich lub dłuższych n-gramów przejętych przez Długosza (jest to w sumie 16 ze wszystkich 36 sekwencji z ks. XII-XXIV). Może to świadczyć o dużym uznaniu historyka dla stylu Petrarki oraz jego dokładnej lekturze listów humanisty. Trzeba jeszcze uwzględnić odpowiednie n-gramy z ks. I-XI dzieła Petrarki (6 ze wszystkich 16 sekwencji). Niestety nie udało mi się wytypować kodeksu, z którego historyk mógł korzystać, czytając pierwszą część listów. Nie potrafię zatem w tej chwili ustalić, kiedy znalazła się ona $\mathrm{w}$ jego posiadaniu, ani jak dużo czasu poświęcił na ich lekturę. $Z$ dużą dozą pewności można za to stwierdzić, że nie znał jej przed czasem opracowania II redakcji tzw. autografu Roczników - w I redakcji bowiem nie ma ani jednej sekwencji z ks. I-XI.

Pozostałe manikuły z ks. XII-XXIV, za pomocą których Długosz oznaczał ważne miejsca lub interesujące frazy, wskazują m.in. przejątki znajdujące się w innych dziełach historyka ${ }^{47}$. Funkcjonowały one także jako stosowne formuły w jego twórczości epistolarnej - takie wykorzystywanie listów było bowiem powszechnie przyjętym zwyczajem tego okresu ${ }^{48}$.

${ }^{44}$ Między innymi Machiavellego; zob. G.F. Mazzotta, Petrarch's Epistolary Epic. Letters on Familiar Matters (,, Rerum familiarum libri”), w: Petrarch. A Critical Guide, s. 319.

45 Catalogus codicum manuscriptorum medii aevi Latinorum qui in Bibliotheca Jagellonica Cracoviae asservantur, t. 2, red. M. Kowalczyk i in., Wratislaviae 1982, s. 346; M. Kowalczyk, Z badań nad życiem i biblioteka, s. 21.

${ }^{46}$ Te 24 oznaczone cytaty stanowią jednak $2 / 3$ wszystkich przejątków z ks. XII-XXIV. Chociaż nie można uznać manikuły za pewny wskaźnik cytowanego miejsca, można ją przynajmniej uznawać za wskazówkę pewnej możliwości cytowania.

47 Wstępna analiza komputerowa pozwoliła znaleźć takie przejątki w Żywocie św. Stanisława oraz katalogach arcybiskupów gnieźnieńskich i biskupów krakowskich. Dokładne badania będą jednak możliwe dopiero w dalszych etapach prac nad korpusem dzieł Jana Długosza.

${ }^{48}$ O powszechności takiej metody pracy z listami zob. J. Domański, Scholastyka i początki humanizmu, s. 118. 
Tabela 3. Glosy Długosza w rękopisie BJ 444

\begin{tabular}{|c|c|c|c|}
\hline Lp. & Glosa Długosza & Lokalizacja & Passus Epistolae familiares Petrarki \\
\hline 1. & de virtutis labore & $9 \mathrm{r}$ & „Quiescere poterat - admirationemque conciliet” (XIII 4, 10) \\
\hline 2. & nota de tribus stilis & $10 \mathrm{v}$ & „Tres equidem - »extenuatum« dicit” (XIII 5, 16) \\
\hline 3. & vis animi & $13 \mathrm{v}$ & „Sub hac ergo - possit assurgere” (XIII 8, 15) \\
\hline 4. & ira & $13 \mathrm{v}$ & „De quo - et Seneca” (XII 14, $3^{49}$ ) \\
\hline 5. & Creta & $23 \mathrm{v}$ & „Rodus, fidei clipeus - periculum fluctuat” $(X V 7,14)$ \\
\hline 6. & nota de philosophia quid est & $34 \mathrm{r}$ & „Tu veram - multi credunt” (XVII 1,7$)$ \\
\hline 7. & $\begin{array}{l}\text { legum auctores et que sit } \\
\text { vera lex }\end{array}$ & $34 \mathrm{v}$ & „Quod si - erroribus extruxerunt” (XVII 1, 22) \\
\hline 8. & magnitudo vera & $35 \mathrm{r}$ & „Vis tu - veritate despicies” (XVII 1, 40) \\
\hline 9. & nota Sardanapalus & $37 \mathrm{r}$ & „Superba Babilon - abitura velocius” (XVII 3, 44) \\
\hline 10. & baptismus Augustini & $40 \mathrm{r}$ & „Ambrosii basilica - sumpsisse compertum est” (XVII 10, 13) \\
\hline 11. & nota Catilina & $42 \mathrm{v}$ & „In te, magnanime Cesar - consultasse consilium sit” (XVIII 1,48$)$ \\
\hline 12. & Titus Livius & $43 \mathrm{r}$ & „Nullum unum - scidit ignavia” (XVIII 3, 8) \\
\hline 13. & $\begin{array}{c}\text { Ianuensium classis accedit ad } \\
\text { insulam Sapientiam }\end{array}$ & $51 \mathrm{v}$ & „Itaque cum se - armatus interfuit” (XIX 9, 17) \\
\hline 14. & laus Italie & $53 \mathrm{r}$ & „Siquid amabile est - aliquid institui” (XIX 14, 2) \\
\hline 15. & vici quanta vis & $57 \mathrm{r}$ & „Aurum solutos - solicitisque segnitiem” (XX 1, 23) \\
\hline 16. & Lucius Florus & $57 \mathrm{v}$ & „Heu, quid nunc - dictante profuderim” (XX 2, 4) \\
\hline 17. & Solon & $58 \mathrm{r}$ & „Harum igitur - experientia defuisset?” (XX 4, 7) \\
\hline 18. & etas Cyceronis & $68 \mathrm{v}$ & „Christum, fateor - et dixisse” (XXI 10, 12) \\
\hline 19. & Iherusalem & $84 \mathrm{r}$ & „Non vigilanti - pene captiva” (XXIII 2,38$)$ \\
\hline 20. & laus magni Ciceronis & $88 \mathrm{r}$ & „Quid expectas - plurimum deprehenditur” (XXIII 12, 33) \\
\hline 21. & $\begin{array}{c}\text { contra eos, qui pluraliter } \\
\text { scribunt }\end{array}$ & $88 \mathrm{v}$ & „Non exiguum - bella distractus” (XXIII 14, 1) \\
\hline 22. & Venecia alter mundus & $89 \mathrm{r}$ & „Nil novi - diversus effectus?” (XXIII 16, 3) \\
\hline 23. & laus adolescentis & $90 \mathrm{r}$ & „Anno exacto - est optimum, tenax” (XXIII 19, 1) \\
\hline 24. & CCCL epistolae Francisci & $90 \mathrm{r}$ & „Familiares epystolas - quinquaginta complebunt” (XXIII 19, 7) \\
\hline 25. & levitas Neronis & $95 \mathrm{r}$ & „Quid enim - egregius citharista?” (XXIV 5, 21) \\
\hline 26. & $\begin{array}{c}\text { noticia familiarum illustrium } \\
\text { Romanarum }\end{array}$ & $96 \mathrm{r}$ & „Verum hec - etatem agere” (XXIV 8, 4) \\
\hline
\end{tabular}

Przejęte sekwencje Długosz wplatał do tekstu Roczników w podobny sposób, jak to czynił w wypadku cytatów z De remediis utriusque fortunae. Najdłuższe z nich służą zazwyczaj jako gotowy schemat charakterystyki postaci, np. Wincentego Kadłubka - zdaniem Długosza, który wykorzystuje tu wiernie słowa Petrarki, narodziny tego biskupa i historyka musiały odbywać się pod szczęśliwą gwiazdą, gdyż bez niczyjej pomocy stworzył wielkie i wspaniałe dzieło (poz. 29: „quem tam benigno lumine astra respexerant, ut sine externe opis adminiculo [novum condendo corpus de annalibus Polonorum [...] expresserit]"). W podobny sposób wykorzystuje inne passusy, w których charakteryzuje: Bolesława Krzywoustego (poz. 30: „licet itaque numero inferior, suos tamen pro tempore magnifice ac breviter hortatus, manum cum hoste conserere”), wojewodę Jana z Oleśnicy (poz. 44: „nullum insidiosius [ratus] malum quam ubi blandiciis credulitas oppugnatur”), Kazimierza Wielkiego (poz. 47: „virtutibus premia, sceleribus supplicia [compensans]. Bonos in precio haberi, pessimum quemque calcari, florere

${ }^{49}$ W rękopisie BJ 444 list jest wciągnięty do treści listu XIII 8. Obserwacje na temat pomieszania szyku listów w rzeczonym kodeksie zob. N. Contieri, La fortuna del Petrarca in Polonia, s. $162 \mathrm{n}$. 
iusticiam, honorem esse viris fortibus, exulare malos [nobiles et cives et rapto atque iniuria vivere assuetos] bonos autem atque honestos in [suum regnum suique regni] urbes undecumque transferri"), legata papieskiego Rudolfa z Rüdesheim (poz. 55: „ex donis [ipsis saltem] aliqua grata accipere in animum induceret, iterum atque iterum”), Mieszka I (poz. 69: „cuius [liczet] castissima fuerit adolescencia, libidinosa [tamen] et lasciviens [fuit] etas provectior”), Bolesława Chrobrego (poz. 71: „mirator amatorque rerum excellencium, auri vero opumque fallacium, nisi pro necessitate, contemptor"), rycerzy Bartłomieja Buczackiego i Jana Łaszcza (poz. 72: „Spectatam usque ad crudelissimam mortem [Bartholomei Buczaczki et Ioannis Lyascz ideo retuli] fidem [et virtutem, ut constancia illorum] in omni futuri temporis perennitate singulari laude"). Jeden tylko raz dłuższy cytat posłużył Długoszowi do podsumowania wydarzenia, a nie charakterystyki postaci, mianowicie przy opisie wyjątkowo ciepłej zimy w 1412 r. (poz. 61: ,[hiems calidissima [...] adeo, ut [...] vulgo pene in miraculum atque, ut dici solet, in religionem fuerit").

Należy zwrócić uwagę także na wykorzystanie przez historyka dłuższych sekwencji przejętych z listów Petrarki w celu zretoryzowania czy też swoistego wzmocnienia wypowiedzi ustnej lub pisemnej. Taki sposób wykorzystania cytatów widzimy po raz pierwszy w przytoczonym przez Długosza odpisie listu Zbigniewa Oleśnickiego do Jana Kapistrana (poz. 60). Nie da się jednoznacznie określić, czy jest to list samego kardynała, czy też jego notariusza - Długosza. Za autorstwem tego drugiego (lub faktem zmodyfikowania przez niego oryginału na potrzeby Roczników) przemawia wplecenie oznaczonego własną manikułą przejątku z dzieła Petrarki. Potwierdzałyby się więc wcześniejsze przypuszczenia co do możliwego wykorzystywania listów włoskiego humanisty przez Długosza w twórczości epistolarnej.

Drugim świadectwem retoryzowania wypowiedzi za pomocą słów Petrarki jest opis spotkania Jana Długosza ze wspomnianym już legatem Rudolfem z Rüdesheim (poz. 55). Wysłany przez króla Kazimierza poseł zachęca papieskiego wysłannika do sprawiedliwej mediacji w sporze z Krzyżakami. Przytacza przykład poprzedniego legata, arcybiskupa Krety Hieronima, który, przekupiony przez mistrza zakonnego, doprowadził do nieakceptowalnego wyroku i przedłużenia działań wojennych. Wpleciony w narrację cytat z Petrarki - drastyczny obraz przelewu krwi i nieustającej walki - może być zarówno przytoczeniem rzeczywistych słów Jana Długosza, jak i jego późniejszym dodatkiem do tekstu. W obu jednak wypadkach jest dowodem silnego zretoryzowania wypowiedzi historyka i dowodzi jego znakomitej znajomości listów włoskiego autora. Warto również zauważyć, że opisując zachowanie arcybiskupa, Długosz używa słów „,verum Cretensem se gerere”, odwołując się do obecnego już w literaturze antycznej motywu Kreteńczyków jako kłamców ${ }^{50}$.

Ponadto niezwykle interesująco prezentuje się nagromadzenie kilku dłuższych przejątków w księdze VI Roczników. Pod 1176 r. Długosz opisuje próby wpływania przez biskupa krakowskiego Gedkę na Mieszka III Starego, korzystając z anegdoty przytoczonej przez Kadłubka ${ }^{51}$. W silnym uniesieniu duchowny wygłasza mowę, za pomocą której próbuje skłonić księcia do zadbania o ojczyznę oraz ukrócenia jego chciwości i niegodziwości. Zaczerpniętą od starszego historyka wypowiedź Długosz rozbudowuje i modyfikuje, dodając do niej - już w II redakcji - aż trzy długie cytaty z ks. XXIII listów Petrarki (poz. 74, 75, 79). Takie nagromadzenie przejątków w jednym miejscu może świadczyć o tym, że Długosz wykorzystywał poszczególne księgi dzieła w tym samym czasie, rozbudowując narrację pod względem stylistycznym oraz siły wypowiedzi. Pokazuje to również wyraźnie jego metodę pracy z tekstem źródłowym - myśli o podobnej tematyce (oba wykorzystane listy z tej księgi odnoszą się do kwestii politycznych) umieszcza w Rocznikach w stosownych miejscach, unikając możliwego przy

\footnotetext{
${ }^{50}$ Motyw ten jest obecny zarówno u autorów greckich (Kallimach), jak i łacińskich (Owidiusz, Lukan) - tych drugich Długosz znał dobrze. Kreteńska kłamliwość musiała być mu także znana z listu św. Pawła do Tytusa (Tt 1,12), gdzie apostoł cytuje oryginalną wypowiedź Epimenidesa z Krety: „Cretenses semper mendaces malae bestiae ventres pigri”; cyt. za: <https:// www.academic-bible.com/en/online-bibles/biblia-sacra-vulgata/read-the-bible-text/bibel/text/lesen/stelle/66/10001/19999/ ch/15da02a7362aa9bad62181bf63348664/> [dostęp: 28.03.2020]; zob. A. Strataridaki, Epimenides of Crete. Some Notes

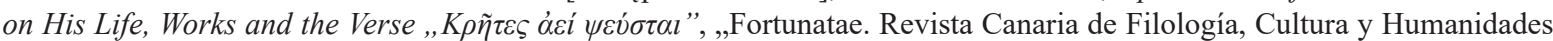
Clásicas", 2, 1991, s. 217-221.

${ }^{51}$ Magistri Vincentii dicti Kadtubek Chronica Polonorum, wyd. M. Plezia, Kraków 1994, s. 135-138 (IV 2,26-4,4).
} 
wtrącaniu nowych elementów rozbicia jedności wypowiedzi. Dowodzi to jednoznacznie, że Długosz korzystał ze swoich źródeł literackich w sposób świadomy i przemyślany.

Średnie n-gramy, w liczbie dziesięciu, funkcjonują w obrębie całego dzieła jako komentarze autora z elementami charakterystyki: cierpliwości posła (poz. 31: „non prius tamen inde discessit, donec [audivit]”), siły charakteru Zbigniewa Oleśnickiego (poz. 39: „quid iocundius, quid felicius, quid venustius [excogitari possit]”) czy wojowniczości polskich rycerzy (poz. 64: „ad Marcialia opera ardenciores quam nature moribusque eorum [et viribus] conveniret"). Służą też do przedstawienia czynów postaci (poz. 40: „simul et cum hoste et cum loco pugnare [cogerentur]”) lub działań wojennych (poz. 58: „,irarum [atque bellorum] flammas, largo hactenus cruoris [mutui] imbre [productas], lentescere [contingeret]"). Stanowią także element wypowiedzi postaci: Bolesława wyrażającego nadzieję na zwycięstwo (poz. 53: „[omnis] spes in presidio celesti et virtute reponenda”), Witolda w obliczu nadchodzącej śmierci (poz. 54: „,dolor animi morbum corporis mortemque [credebatur] conflavisse”) czy wreszcie komtura de Wende w sprawie wojny z Polakami (poz. 59: „quid pax quid bellum ferat experto”). Wszystkie te cytaty nie wnoszą jednak do narracji dodatkowych treści, służą jedynie stylistycznemu wzbogaceniu tekstu lub pogłębieniu jego wymowy.

Jeżeli chodzi o średnie sekwencje, warto również zauważyć, że jedna z nich (poz. 52: „,avariciam in te suspicari nequeo") pojawia się jako zdanie wtrącone w analizowanej przedtem wypowiedzi biskupa Gedki. Sekwencja ta pochodzi z ks. XV listów, a w Rocznikach znalazła się już w I redakcji. Może to świadczyć o wcześniejszej niż w wypadku ks. XXIII lekturze Długosza tej części dzieła Petrarki, nawet mimo braku znacznika mnemotechnicznego w rękopisie przy przejętym cytacie.

Z Epistolae familiares pochodzi także największa liczba wspólnych krótszych n-gramów. Część z nich została oznaczona w trakcie lektury rękopisu listów i wtrącona później w tok narracji dzieła (poz. 45, 49, $51,63,65,68,76,78)$. Pozostałe sekwencje nie mają punktu odniesienia w postaci manikuły Długosza (poz. 28, 32-38, 41, 43 z ks. I-XI oraz poz. 46, 48, 50, 56, 57, 62, 67, 70, 76, 77 z ks. XII-XXIV), co może świadczyć o całkowicie lub częściowo nieświadomym przyswajaniu stylu i słownictwa Petrarki. Przejątki pojawiają się w passusach o różnorodnej tematyce i formie. Występują w komentarzach narratora, budują charakterystykę lub wypowiedź postaci oraz opisują pojedyncze wydarzenia. Często funkcjonują również pod postacią zdania predykatywnego - działa tak m.in. fraza „stupendum dictu” (poz. 43), która otwiera zdanie o wszechmocy Boga.

W świetle powyższych obserwacji łatwo zauważyć, że polski historyk traktuje wszystkie części kroniki równorzędnie i stara się wzbogacić stylistycznie jak największą jej część. Stopień wykorzystania listów pokazuje jego dobrą znajomość także tej części twórczości Petrarki i chęć jej wyzyskania, a występujące $\mathrm{w}$ różnych redakcjach cytaty dowodzą jego umiejętnej pracy z tym humanistycznym materiałem źródłowym.

\section{d) Epistolae sine nomine, Posteritati (Listy nienazwane, Do potomnych)}

Do omówienia pozostają jeszcze dwa epistolograficzne dzieła Petrarki, z których pochodzi najmniejsza liczba przejątków (odpowiednio trzy i dwa n-gramy). Pierwsze z nich - Epistolae sine nomine zawiera kilkanaście listów, które z różnych przyczyn nie zostały opublikowane w ramach większych zbiorów $^{52}$. Drugie - Posteritati - jest literacką autobiografią włoskiego humanisty, utworem formalnie kończącym Epistolae seniles, funkcjonuje jednak jako odrębne dzieło ${ }^{53}$. W związku z ich niewielkimi rozmiarami nie weszły one prawdopodobnie w skład osobnego kodeksu - były raczej częścią jakiegoś większego zbioru (być może znajdowały się w zaginionym tomie z Epistolae familiares I-XI), mogły również funkcjonować pojedynczo w kolekcjach epistolograficznych, które sporządzano w średniowieczu na potrzeby prac kancelaryjnych ${ }^{54}$. Obecności tekstów Petrarki w takich zbiorach dowodzi pojedynczy

52 R.L. Martinez, The Book Without a Name. Petrarch's Open Secret (,,Liber sine nomine”), w: Petrarch. A Critical Guide, s. 291-293.

${ }^{53}$ D. Wallace, Letters of Old Age. Love Between Men, Griselde, and Farewell to Letters (,, Rerum senilium libri”), w: tamże, s. 329.

${ }^{54}$ J. Domański, Scholastyka i początki humanizmu, s. 118. 
list z Listów nienazwanych, który Anna Horeczy odnalazła w rękopisie należącym do Piotra Wolframa ${ }^{55}$. W obu jednak wypadkach nie zachował się żaden kodeks, w którym można byłoby znaleźć wskazane w toku badań listy. Poza tym Długosz wykorzystał je w niewielkim stopniu, mógł więc ich nawet nie mieć na stałe w swojej bibliotece. Z Listów nienazwanych pochodzą dwa dłuższe n-gramy (poz. 80 i 82) oraz jeden średni (poz. 81), natomiast z autobiografii Petrarki - jeden dłuższy (poz. 83) i jeden krótszy (poz. 84). Warto również zauważyć, że obie sekwencje z Posteritati są późnymi dopiskami do Roczników - dłuższa jest na pewno elementem ostatniej redakcji, krótsza być może także.

W przeciwieństwie do poprzednich dzieł do charakterystyki postaci posłużył historykowi tylko krótszy przejątek (poz. 84: „magnanimus diviciarum contemptor”), wykorzystany przy pośmiertnym opisie Bolesława Chrobrego, wzbogacony dodatkowo cytatem z Salustiusza. Pozostałe - dłuższe i średni służą jako rama wypowiedzi dla komentarza o łamaniu przysiąg i praw (poz. 80: „violatum enim ius gencium, spreta [germanitatis, et quod omnia superat], humanitatis federa, in nuncii sui [querebatur] persona”, 81: „nichil sancti, nichil pensi, nichil iusti”) i o wartości czyichś słów (poz. 82: „Graviter inquit - et libere [etsi regiis] auribus [severe, ut retur ipse], et importune, meis certe [et aliorum] fidentissime et ut [Cracoviensem pontificem Stanislaique sanctissimi dignum successorem] decuit, verissime loquutus es”). Ostatnia z tych sekwencji (poz. 83: „Discordia [autem] scriptorum, [plerumque levitate et negligencia] offensus, secutus [sum in relacionibus et rebus ambiguis], quo me vel similitudo rerum vel scribencium auctoritas aut [opinio] traxit") służy Długoszowi do poczynienia odautorskiej uwagi na temat sposobu korzystania ze źródeł historycznych. Historyk rozbudowuje nieco słowa Petrarki, wciąż jednak stanowią one, podobnie jak w wypadku wielu innych dłuższych n-gramów, podstawę jego wypowiedzi.

\section{Wnioski}

Przed szczegółowym podsumowaniem dotychczasowych wyników analizy warto się jeszcze przyjrzeć ogólnemu rozmieszczeniu wspólnych sekwencji Petrarki i Długosza w obrębie poszczególnych ksiąg Roczników (zob. wykres 2).

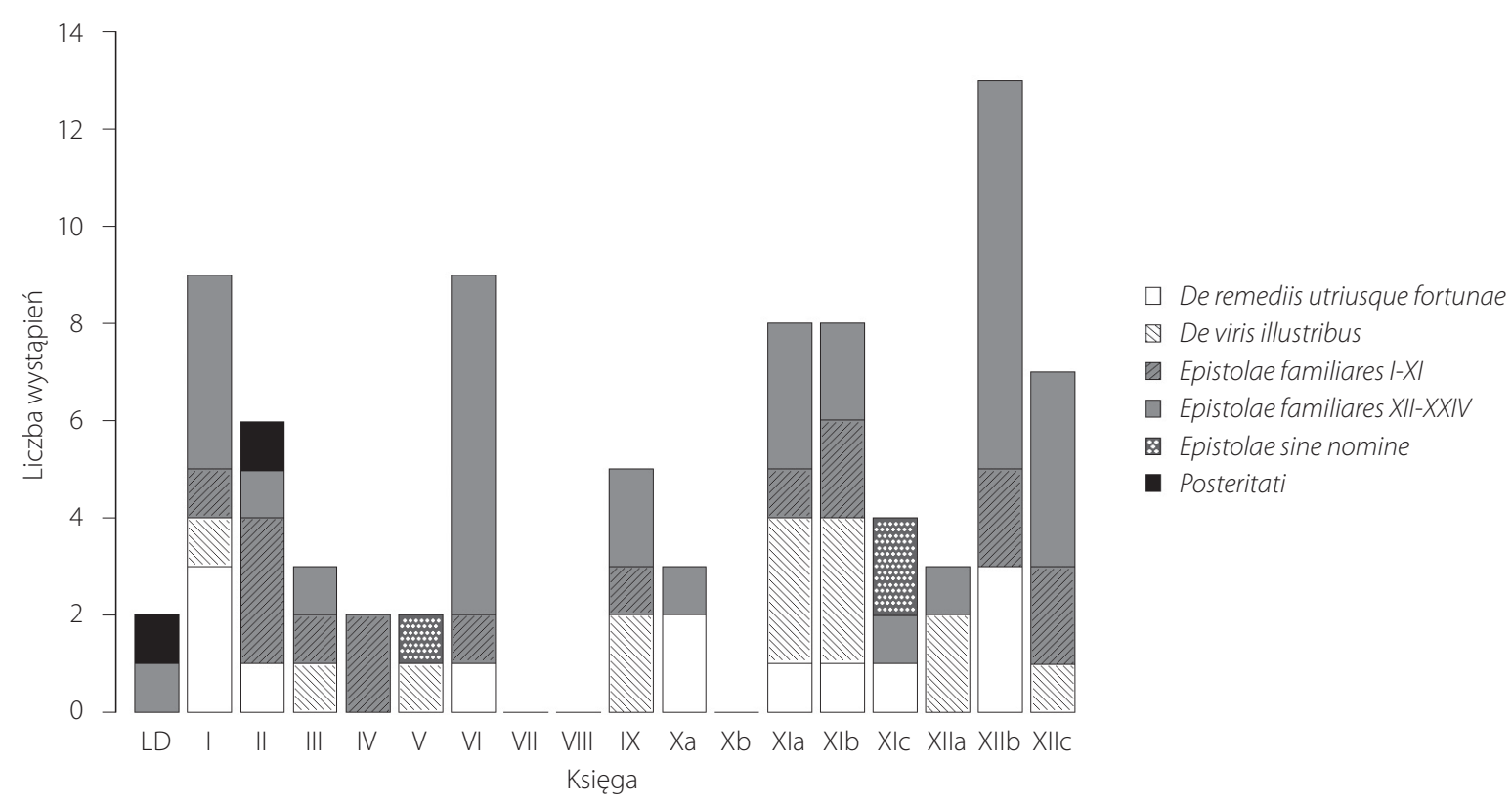

Wykres 2. Dystrybucja przejątków z dzieł Petrarki w obrębie Roczników Jana Długosza

${ }^{55} \mathrm{O}$ znalezisku tym i identyfikacji go z listem Petrarki dr Anna Horeczy wspomniała w dyskusji po moim wystąpieniu na seminarium doktorskim prof. Marii Koczerskiej i dr. hab. Piotra Węcowskiego w Instytucie Historycznym UW. Jest to list XII (inc. „Ve populo tuo, Christe Ihesu”, zob. rkps BJ 344, k. 247r), za którego wskazanie Pani Doktor serdecznie dziękuję. 
$\mathrm{Z}$ analizy powyższego wykresu możemy wyciągnąć następujące wnioski. Po pierwsze, zauważyć można względnie równy udział przejątków w obrębie obu części Roczników (41 w części historycznej i 43 w części współczesnej ${ }^{56}$ - trzeba mieć oczywiście na uwadze to, że różnice udziału sekwencji w obrębie poszczególnych ksiąg są już bardzo duże). Dowodzi to równorzędnego traktowania przez autora obu partii tekstu z punktu widzenia dbałości o kunsztowność warsztatu literackiego. Jest to widoczne zwłaszcza w części historycznej - w tzw. autografie - gdzie duża liczba przejątków ( 28 z 42 , czyli $66 \%{ }^{57}$ ) pojawia się dopiero w II, III lub „IV” redakcji ${ }^{58}$. Jest to również świadectwem pracy historyka nad ogromnym dziełem aż do ostatnich lat życia (w najpóźniejszych dopiskach znalazły się jeszcze trzy cytaty z Petrarki, poz. 12, 51, 83).

Ważnych informacji dostarcza również obserwacja dystrybucji przejątków z poszczególnych dzieł Petrarki - na wykresie widać dominację Epistolae familiares w obrębie całego dzieła. Co więcej, ich rozmieszczenie w części historycznej i współczesnej jest identyczne - w obu częściach jest razem po 26 cytatów. W drugiej części kroniki dominują natomiast cytaty z De viris illustribus. Kluczem do zrozumienia takiego właśnie rozkładu może być tematyka dzieł - historyk sięga bowiem szczególnie chętnie po elementy charakterystyki osób, za pomocą których może później opisywać swoich bohaterów, a przecież oba wymienione dzieła Petrarki obfitują w opisy postaci.

Warto również zwrócić uwagę na księgi, w których wspólne sekwencje nie pojawiają się w ogóle, a mianowicie ks. VIII (obejmującą lata 1295-1299) i ks. Xb (obejmującą lata 1407-1409). Znaczenie może mieć rozmiar obu ksiąg - są to dwie najkrótsze księgi Roczników, które także pod względem treściowym (ilości opisywanych zdarzeń) przedstawiają się nader skromnie. Możliwe, że z tego powodu historyk poświęcił im mniej uwagi przy doskonaleniu tekstu od strony literackiej. Dziwić może natomiast zupełny brak sekwencji zaczerpniętych z dzieł Petrarki w ks. VII (obejmującej lata 1241-1294).

Po dokonaniu szczegółowej analizy wytypowanych na podstawie opracowanego programu przejątków z Petrarki w tekście Roczników (także pod kątem ich dystrybucji w dziele Długosza), by lepiej zrozumieć kryteria, jakimi kierował się kronikarz, sięgając po wzorce włoskiego mistrza, należy zwrócić uwagę przede wszystkim na trzy kwestie: obszar tematycznych zainteresowań Długosza, czas jego lektury dzieł Włocha oraz sposób pracy Długosza ze źródłami.

Jak wykazano, podczas lektury Petrarki Długosz sięgał najchętniej po takie frazy i zdania, które mogły mu posłużyć przy opisie postaci. Tę grupę stanowią zarówno rozbudowane przydawki w formie krótszego n-gramu (poz. 84: „divitiarum contemptor eximius”), jak i całe złożone podrzędnie zdania (poz. 5: „talis [vir est ablatus], qualem, ut auguror, secula nulla restituent”). Widać tu, że historyka interesuje bardziej charakterystyka indywidualna niż przedstawianie cech grupy.

Równie chętnie wykorzystuje on sekwencje odnoszące się do sfery militarnej - zarówno te krótsze, jak i dłuższe. Dotyczą one wielu jej aspektów: samych działań wojennych (poz. 16: „equo calcaribus adacto [contorquens]”, 66: „quicquid [...] citroque sanguinis fusum fundendumque est, quicquid telorum [hincinde] volitat”), taktyki i strategii (poz. 25: „non a fronte sed a tergo, [nullam custodiam illic]

56 Zob. Ioannis Dlugossii Annales seu Cronicae incliti Regni Poloniae, ks. I-II, Varsoviae 1964, s. 12-15.

${ }^{57} \mathrm{~W}$ tym 11 średnich lub dłuższych, a więc o stosunkowo wysokim stopniu prawdopodobieństwa pochodzenia z analizowanych dzieł.

${ }^{58}$ Przynależność danej sekwencji do określonej redakcji autografu określono przede wszystkim na podstawie: W. Semkowicz-Zarembina, Powstanie i dzieje autografu „Annalium” Jana Dlugosza, Kraków 1953, s. 78-86. Polemikę z niektórymi ustaleniami badaczki prowadził P. Dymmel, który przekonująco przesunął w czasie II i III redakcję dzieła oraz wysnuł wniosek o istnieniu „IV” redakcji (a przynajmniej jej zapowiedzi), którą stanowiły dopiski do partii tekstu wygładzonych już wcześniej (tj. do listu dedykacyjnego i chorografii). Jako że analizowane tutaj przejątki pojawiają się również w tych partiach, zdecydowałem się na przyjęcie ustaleń P. Dymmela i każdorazowe zaznaczanie przynależności do tej ostatniej redakcji (zob. aneks); zob. P. Dymmel, Uwagi nad historia tekstu w autografie „Annales” Jana Dhugosza, w: Venerabiles, nobiles et honesti. Studia z dziejów społeczeństwa Polski średniowiecznej. Prace ofiarowane profesorowi Januszowi Bieniakowi w siedemdziesiąta rocznicę urodzin i czterdziestopięciolecie pracy naukowej, red. A. Radzimiński, A. Supruniuk, J. Wroniszewski, Toruń 1997, s. 467-476. Krótkie podsumowanie tej dyskusji przedstawił niedawno W. Drelicharz, Miejsce „Excerpta ex fontibus incertis” w warsztacie historiograficznym Jana Dlugosza, w: Jan Dlugosz (1415-1480). Życie i dzieła, red. L. Korczak, M.D. Kowalski, P. Węcowski, Kraków 2016, s. 74. 
consistere [rati], Cruciferis [apcior] videbatur”), rezultatu starć (poz. 58: „,irarum atque bellorum flammas, largo hactenus cruoris [mutui] imbre [productas]"). Takie n-gramy pozwoliły wzbogacić i zdynamizować narrację oraz w widowiskowy sposób przedstawić skrajne odczucia, jakie wojna wywołuje, na przykład grozę, doświadczenie nieszczęścia.

Długosz sięga także po takie sekwencje, które może wykorzystać jako zdania predykatywne (poz. 43: „stupendum dictu”) lub ramę wypowiedzi (poz. 9: „Non est - inquit - amplius cunctandum”, 11: „vix [pontificem] invenies, cui”, 45: „nullo unquam tempore”). W taki sposób uzyskuje on zazwyczaj dogodną okazję do wyprowadzenia kolejnego zdania lub podsumowania partii tekstu, co wydatnie wpływa na ogólny styl dzieła.

Długosz wzbogaca materiał rocznikarski nie tylko o urozmaicone charakterystyki oraz plastyczne opisy batalistyczne przejęte dosłownie z utworów Petrarki, ale także o osobiste komentarze, często wzorowane na wypowiedziach włoskiego humanisty. Owa dbałość o bogactwo stylistyczne i właściwy dobór cytatów do opisywanego tematu przyświeca mu aż do końca prac nad dziełem, o czym świadczy również pewna liczba przejętych n-gramów w dopiskach z ostatnich redakcji tzw. autografu. Warto nadmienić, że powyższe obserwacje pokrywają się w pewnym stopniu z uwagami innych badaczy na temat zainteresowań Długosza literaturą klasyczną ${ }^{59}$.

Na podstawie wspólnych z Petrarką sekwencji znajdujących się w tzw. autografie możemy ponadto określić czas prawdopodobnej lektury dzieł włoskiego autora. Najwcześniej sięgnął po ks. XII-XXIV Epistolae familiares, które znalazły się w jego posiadaniu w 1443 r., po śmierci Mikołaja Kozłowskiego. Na długą i wnikliwą lekturę dzieła wskazuje przede wszystkim ogromna liczba znaków mnemotechnicznych w rękopisie, które różnią się między sobą wariantami - może to świadczyć o ewolucji grafii Długosza, a więc także o wielokrotnym powracaniu do listów Petrarki. Bez dokładniejszych badań nie sposób jednak ustalić jednoznacznie, czy te warianty rzeczywiście prezentują poszczególne okresy lektury dzieła ${ }^{60}$.

Szczególną uwagę należy zwrócić na zauważone powyżej nagromadzenie przejątków z ks. XXIII Epistolae familiares w dopiskach z II redakcji Roczników. Na tej podstawie można wyciągnąć wniosek, że treści z tej księgi wykorzystywał kronikarz znacznie później niż z poprzednich, choć nie musi to świadczyć przeciw wczesnej jej lekturze. Jeden z oznaczonych przez Długosza manikułą krótszych n-gramów z tej księgi znalazł się przecież już w I redakcji (poz. 78). Dowodzi to raczej wielokrotnego czytania dzieła lub sięgania do sporządzonych przy okazji lektury wypisów z niego.

Inaczej ma się sprawa z pierwszą częścią listów, czyli ks. I-XI. Całkowity brak przejątków w tekście I redakcji sugeruje, że ten zbiór trafił w ręce Długosza dopiero pod koniec lat 60 . XV w., a więc w okresie II redakcji tzw. autografu. Być może wtedy zapoznał się również z Posteritati (o czym mógłby świadczyć dodatek z II redakcji, poz. 84). Cytat wpleciony do kroniki w postaci dopisku do listu dedykacyjnego (poz. 83) każe jednak przesunąć czas lektury tego dzieła raczej na końcówkę lat 70. - również wtedy Długosz mógł przecież dopisywać pojedyncze treści do jeszcze nieprzerobionych partii Roczników.

Otwarta pozostaje kwestia wykorzystania pozostałych trzech dzieł włoskiego humanisty. Cytaty z De remediis utriusque fortunae, De viris illustribus oraz Epistolae sine nomine znajdują się co prawda w tekście I redakcji tzw. autografu, ale znacznie ich więcej występuje w III redakcji. Pojedyncza

59 W kwestii wykorzystywania opisów wojen i postaci zob. J. Schnayder, Salustiuszowe echa, s. 145-148; W. Madyda, Wzory klasyczne, s. 178-201; M. Kowalczyk, Jagiellońskie rękopisy Liwiusza, s. 225-229 (zwięzłe podsumowanie ich badań przedstawia W. Semkowicz-Zarembina, Elementy humanistyczne redakcji „Annalium” Jana Dhugosza, w: Mediaevalia. W 50 rocznice pracy naukowej Jana Dąbrowskiego, red. J. Garbacik, Warszawa 1961, s. 244-251). W kwestii wykorzystania odautorskich komentarzy Liwiusza zob. M. Rzepiela, Rola frazeologii w narracji „Kroniki” Jana Dlugosza, w: Jan Dlugosz (1415-1480). Życie i dzieła, s. 247.

${ }^{60}$ Różnice pomiędzy poszczególnymi wariantami dotyczą grubości palca wskazującego oraz kształtu mankietu. Osobiście uważam, że najwcześniejszym wariatem jest ten spotykany w rkps. BJ 721 oraz w innych kodeksach, m.in. gdzieniegdzie w rkps. BJ 444 (zob. k. 46v), a także we wspomnianym już wcześniej kodeksie BJ 523 (zob. k. 24r) - z szerokim, pofalowanym mankietem oraz z niezwykle cienkim, stanowiącym praktycznie linię, palcem wskazującym. 
sekwencja została wykorzystana nawet w najpóźniejszych dopiskach do chorografii (poz. 12). Ponieważ jednak wykorzystanie przejątków z tych dzieł jest nieznaczne, a manikuły w rękopisie BJ 721 są nieliczne i reprezentują tylko jeden wariant graficzny, można uznać, że ich lektura nie była tak systematyczna, jak w wypadku kodeksu BJ 444. Być może Długosz nie miał do nich tak swobodnego dostępu, ponieważ wypożyczał dzieła od kogoś tylko na jakiś czas ${ }^{61}$.

Nie można również podać dokładnych ram czasowych pracy historyka z tymi tekstami, chociaż w jego rękach musiały się one znaleźć jeszcze przed zakończeniem I redakcji tzw. autografu, czyli przed 1468 r. (który na potrzeby naszych rozważań będzie stanowił umowną granicę w pozyskiwaniu materiału źródłowego przez Długosza ${ }^{62}$ ). Podsumowując: trzy omówione powyżej dzieła wraz z drugą połową Epistolae familiares stanowią wczesne lektury Długosza (sprzed 1468), natomiast Posteritati oraz pierwsza połowa Epistolae familiares należą do lektur późniejszych (po 1468).

Omówiona w poprzednim rozdziale kwestia wykorzystywania przejątków z Petrarki w różnych redakcjach Roczników wykazała, że pojedyncze sekwencje, z którymi Długosz mógł zapoznać się dosyć wcześnie, były wykorzystywane przez niego stosunkowo późno. Można zatem założyć, że nie mając stałego dostępu do niektórych dzieł, polski historyk sporządzał z nich wypisy na własny użytek, gromadząc je w kartotece, do której sięgał w późniejszym etapie pracy - o możliwości istnienia takiej kartoteki ekscerptów pisała już M. Kowalczyk ${ }^{63}$.

Takie wytłumaczenie może być bardzo prawdopodobne. Po pierwsze, wyjaśniałoby, dlaczego pojedynczy, wcześnie czytany i oznaczony manikułą passus w rękopisie BJ 721 „znalazł zastosowanie” dopiero w najpóźniejszych dopiskach do kroniki (w podobny sposób wykorzystany został przejątek z De viris illustribus, poz. 25) ${ }^{64}$. Po drugie, stanowiłoby odpowiedź na pytanie, dlaczego tak niewiele miejsc w omówionych rękopisach zajmują Długoszowe glossy i dlaczego tak wiele znaków mnemotechnicznych jest w kodeksie BJ 444. Odnalezienie konkretnej informacji w takim gąszczu symboli mogłoby stanowić niemałe wyzwanie. Hipoteza kartoteki zdaje się rozwiązywać ten problem - manikuły wskazywałyby miejsca, które należało przepisać (czy Długosz robił to sam, czy zlecał komuś innemu, nie wiadomo ${ }^{65}$ ), natomiast pojedyncze glosy stanowily jedynie komentarz do lektury, uwagę na marginesie dla samego siebie. Tłumaczyłoby to fakt wspominanego już nagromadzenia przejątków z ks. XXIII przy jednoczesnym wykorzystaniu sekwencji z tej księgi w innych redakcjach - właściwe cytaty mogły zostać spisane wcześniej, a znalazły się w Rocznikach dopiero w trakcie poprawek w II redakcji.

Po trzecie, hipoteza kartoteki wyjaśniałaby również, dlaczego wplatane w narrację kroniki cytaty z Petrarki (oraz innych lektur Długosza) tak często podlegają szerokim modyfikacjom i amplifikacjom. Chodzi o liczne przesunięcia wyrazów, zmiany form gramatycznych, uzupełnianie cytatów własnymi treściami czy nawet jednoczesną kompilację dwóch lub więcej przejątków na krótkim odcinku tekstu (poz. 10, zob. rozdz. III/2/a). Wydaje się, że praca na żywym materiale przepisywanego dzieła nie dawałaby Długoszowi czasu na tak gruntownie przemyślaną i udaną stylistycznie kompozycję

${ }^{61}$ W tym miejscu należy zauważyć, że brak stałego dostępu do dzieła nie powstrzymywał Długosza przed dokładną jego lekturą - w taki sposób korzystał chociażby z rkps. BN BOZ Cim. 28 (zawierającego m.in. Kronikę Galla Anonima i Rocznik Traski) z kolekcji rodziny Łaskich, który historyk wypożyczył na jakiś czas, pozostawiając w nim liczne adnotacje; zob. W. Drelicharz, Miejsce „Excerpta ex fontibus incertis”, s. 74-78; tenże, Annalistyka małopolska XIII-XV wieku. Kierunki rozwoju wielkich roczników kompilowanych, Kraków 2003, s. 28.

${ }_{62}$ Zob. P. Dymmel, Uwagi nad historia tekstu, s. 469.

${ }_{63}$ M. Kowalczyk, Jagiellońskie rękopisy Liwiusza, s. 229.

${ }^{64}$ Większość wykorzystanych przejątków z De remediis występuje w tekście III redakcji, która zawiera w sobie również tekst pierwotny tzw. autografu; zob. Semkowicz-Zarembina, Powstanie i dzieje autografu „Annalium”, s. 35.

${ }^{65}$ Uważam, że Długoszowe manikuły (a przynajmniej któryś ich wariant, prawdopodobnie ten z grubszym palcem i uproszczonym mankietem) stanowiły wskazówki i oznaczenia dla jego kopistów w okresie, gdy sam historyk miał już znacznie większy dostęp do literatury i dobrze przygotowaną pracownię, której notariusze przepisywali na jego polecenie całe dzieła lub formuły epistolarne; zob. M. Kowalczyk, Pisarze „Annales” Jana Dlugosza, „Biuletyn Biblioteki Jagiellońskiej”, 49, 1999, s. 103-110; M. Koczerska, Familiares Jana Dlugosza, w: Aetas media, aetas moderna. Studia ofiarowane profesorowi Henrykowi Samsonowiczowi w siedemdziesiąta rocznicę urodzin, red. H. Manikowska i in., Warszawa 2000, s. 75-78. 
poszczególnych partii kroniki. Nawet dłuższe odcinki tekstu, przepisywane słowo w słowo z innych dzieł $^{66}$, podlegają $\mathrm{w}$ wersji historyka minimalnym przesunięciom i uzupełnieniom o stosowne wykładniki koherencji i kohezji tekstu ${ }^{67}$.

Na koniec należy wyraźnie zaznaczyć, że proponowana hipoteza kartoteki wymaga jeszcze wzmocnienia o materiał dowodowy z wykorzystania innych dzieł przez Długosza.

\section{Podsumowanie}

Niezaprzeczalny fakt lektury dzieł Petrarki i wykorzystania przejątków z nich w pracy nad Rocznikami dostarcza kolejnego argumentu za humanistycznymi zainteresowaniami Długosza. Lektura ta była systematyczna i służyła historykowi do wybierania takich treści, które mieściły się w obrębie jego preferencji tematycznych (charakterystyka postaci, działania wojenne, ramy narracyjne). Przejątki przyczyniały się także do wzbogacenia stylu kroniki. Wszystko wskazuje również na to, że owa systematyczna lektura mogła prowadzić do powstawania bogatej kartoteki wypisów i ekscerptów z literatury starożytnej, średniowiecznej i humanistycznej, która prawdopodobnie stała się podstawą warsztatu literackiego historyka. Wydaje się więc, że dokładne przebadanie kolejnych dzieł, o których wiadomo już dziś, że jakieś z nich przejątki znajdują się w Rocznikach, a może i w innych pismach kronikarza, jest warunkiem sine qua non pełnego zrozumienia charakteru jego twórczości i wszelkich ewentualnych rozbiorów krytyczno-literackich kroniki ${ }^{68}$.

\section{Aneks \\ Lista n-gramów wspólnych dla Roczników [dalej: Ann.] Długosza i korpusu dziel Petrarki}

Poniższa lista wyników obejmuje wszystkie wspólne n-gramy dla Roczników i pięciu dzieł Petrarki w następującej, alfabetycznej kolejności:

1. De remediis utriusque fortunae [dalej: De rem.] (poz. 1-13),

2. De viris illustribus [dalej: De vir.] (poz. 14-27),

3. Epistolae familiares [dalej: Ep. fam.] (ks. I-XI: poz. 28-43; ks. XII-XXIV: poz. 44-79),

4. Epistolae sine nomine [dalej: Ep. sine nom.] (poz. 80-82),

5. Posteritati [dalej: Post.] (poz. 83-84).

Lokalizacje dzieł Petrarki odnoszą się do wydań cyfrowych dostępnych we wspomnianych na początku repozytoriach literatury łacińskojęzycznej, zgodnie z układem: księga, rozdział, ustęp. W wypadku Roczników układ to: księga, numer strony. W kolumnie „Uwagi” podano najważniejsze informacje dodatkowe o danym n-gramie lub jego przynależność do redakcji Roczników. Pogrubieniem zaznaczono poszczególne sekwencje oraz wspólne wyrazy z ich najbliższego otoczenia.

${ }^{66}$ U. Borkowska, Treści ideowe w dziełach Jana Dlugosza. Kościót i świat poza Kościołem, Lublin 1983, s. 186, przyp. 10. Autorka nie omawia szczegółowo kwestii wykorzystania Fortalitium fidei Alfonsa ze Spiny, z którego Długosz zaczerpnął dosłownie treści z dwóch rozdziałów. Zamienia on jednak miejscami niektóre akapity i dodaje od siebie do przeobrażonego tekstu pojedyncze operatory jego kohezji i koherencji, m.in. partykuły, spójniki i zdania podrzędne. Dzięki takim zabiegom przejęty passus uzyskuje spójność i ,zamknięty” charakter.

${ }^{67}$ Pod pojęciem „koherencja” rozumiem spójność syntaktyczną tekstu, czyli międzyzdaniową, pod pojęciem „kohezja” - spójność semantyczną (wewnątrzzdaniową) tekstu. Więcej o środkach i wykładnikach spójności zob. H. Wolanin, Gramatyka opisowa, s. 585-608; S. Karolak, Spójność syntaktyczna, w: Encyklopedia językoznawstwa, s. 547 n.; A. Nagórko, Podręczna gramatyka języka polskiego, Warszawa 2012, s. 125-127.

68 Według wstępnych analiz komputerowych lista „nowych” autorów, z których mógł korzystać Długosz, wygląda obiecująco - są na niej m.in. Kurcjusz Rufus, Ambroży z Mediolanu, Jan z Salisbury i inni. Wierzę, że wraz z rozwojem projektu „Długosz 2.0” nasza znajomość literackich źródeł i inspiracji „ojca polskiej historiografii” będzie stale wzrastać. 


\begin{tabular}{|c|c|c|c|c|c|c|}
\hline ס & 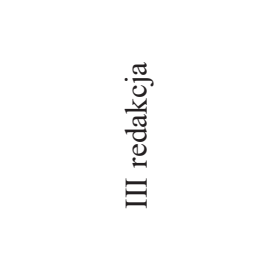 & 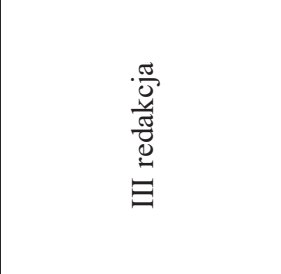 & 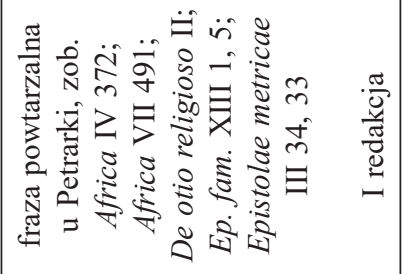 & 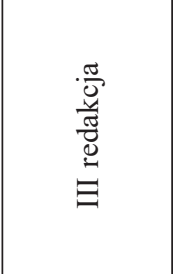 & 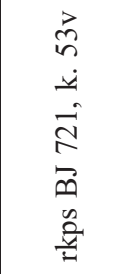 & 1 \\
\hline 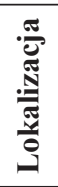 & 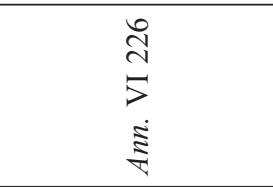 & 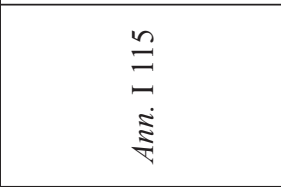 & 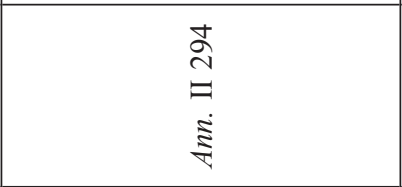 & $\begin{array}{l}\text { ले } \\
\Xi \\
\dot{\Xi}\end{array}$ & 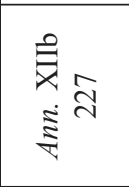 & $\begin{array}{l}\stackrel{\pi}{x} \\
\stackrel{m}{\Sigma}\end{array}$ \\
\hline 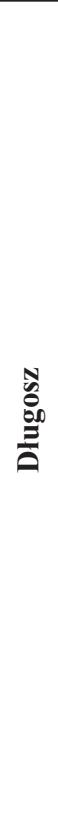 & 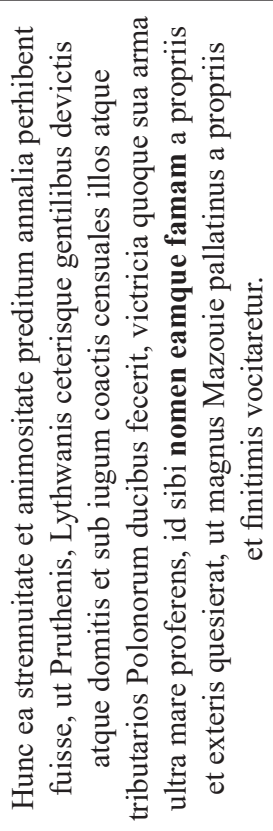 & 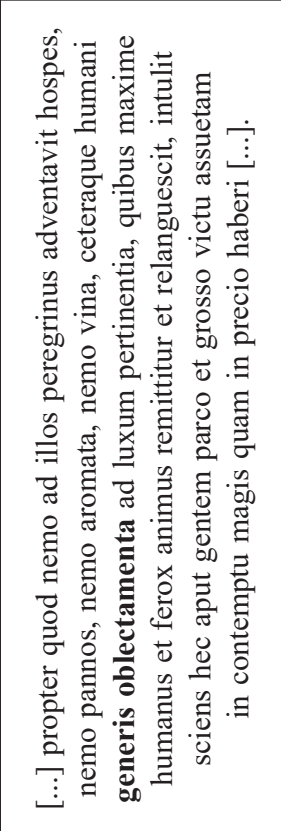 & 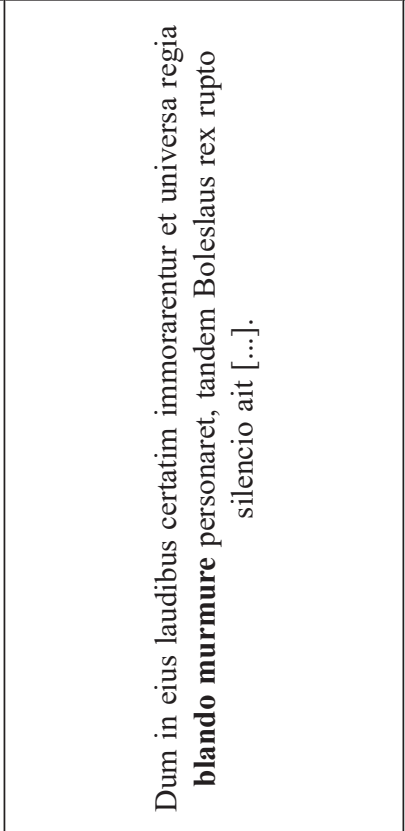 & 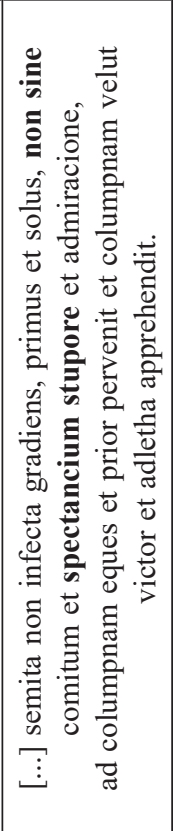 & 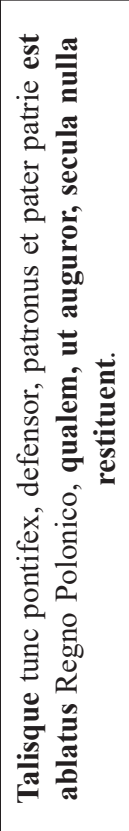 & 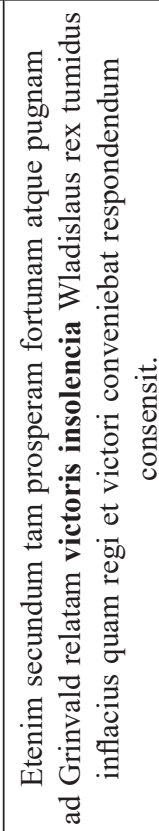 \\
\hline 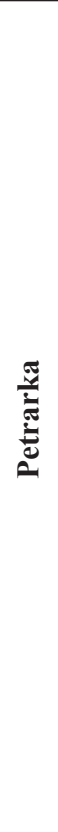 & 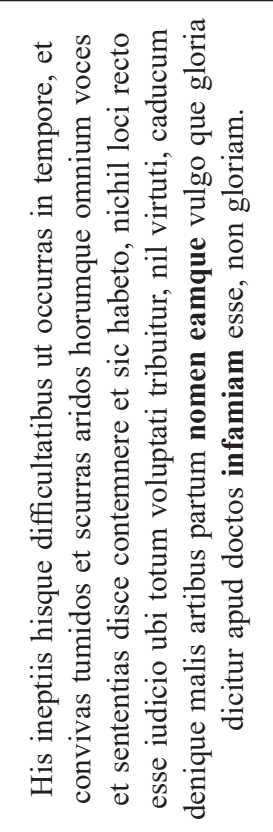 & 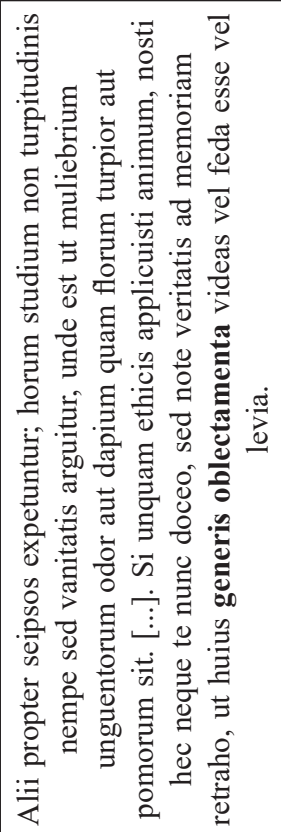 & 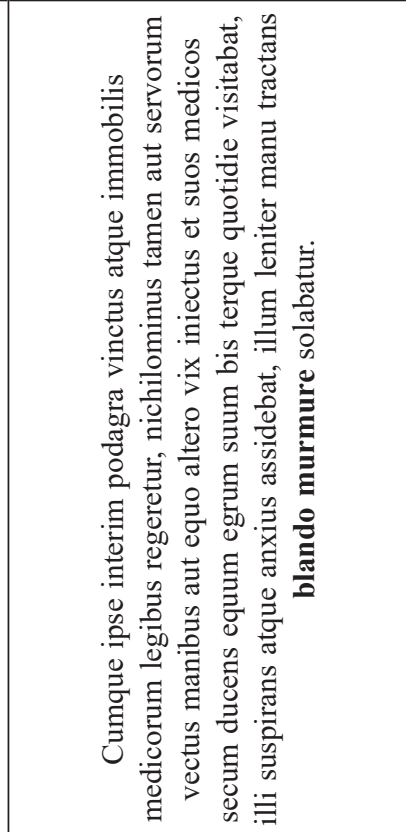 & 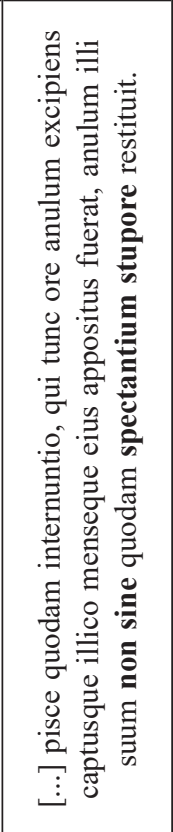 & 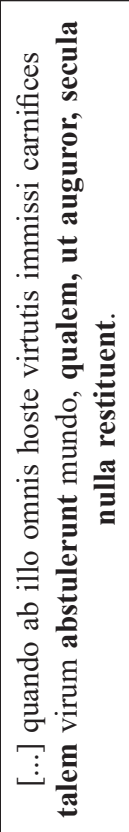 & 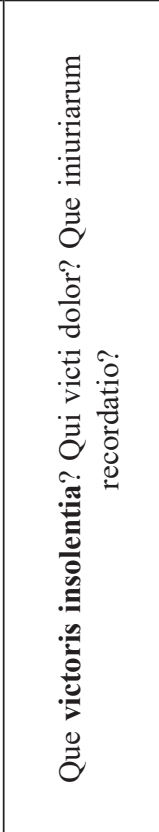 \\
\hline 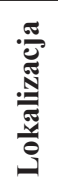 & 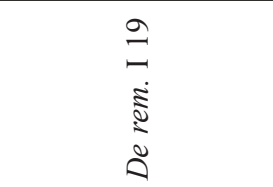 & 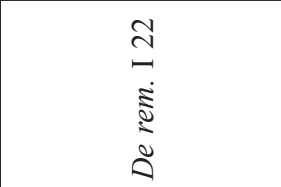 & 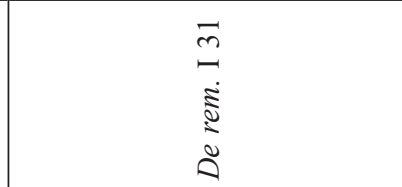 & 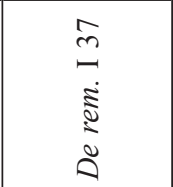 & 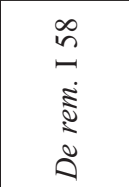 & 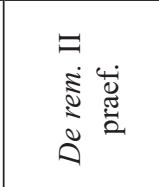 \\
\hline$\dot{\Xi}$ & - & i & $\dot{r}$ & $\dot{\nabla}$ & in & 0 \\
\hline
\end{tabular}




\begin{tabular}{|c|c|c|c|c|c|c|c|}
\hline סू & 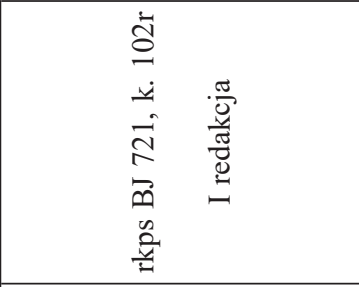 & 1 & 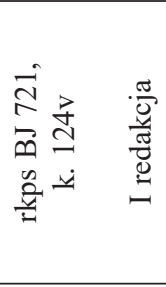 & 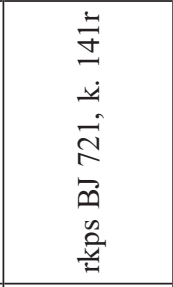 & 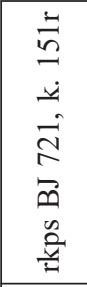 & 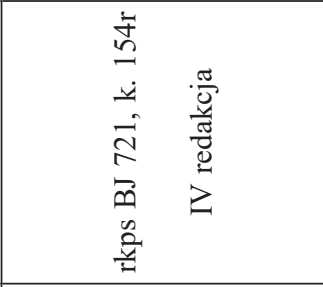 & 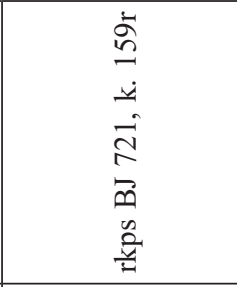 \\
\hline 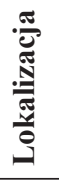 & $\begin{array}{l}\infty \\
\infty \\
\ddot{x} \\
\dot{\Sigma} \\
\dot{\Sigma}\end{array}$ & $\begin{array}{l}\text { ले } \\
0 \\
\dot{x} \\
\vdots \\
\dot{\nabla}\end{array}$ & $\begin{array}{l}\tilde{a} \\
\tilde{x} \\
\tilde{\Sigma} \\
\tilde{\Sigma}\end{array}$ & $\begin{array}{l}\text { m } \\
\tilde{\vec{x}} \\
\vdots \\
\vdots \\
\dot{\nabla}\end{array}$ & $\begin{array}{l}\text { 忞 } \\
\text { ‡ }\end{array}$ & $\begin{array}{l}\sqrt{2} \\
5 \\
5\end{array}$ & 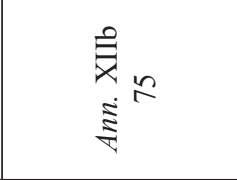 \\
\hline $\begin{array}{l}\text { Oे } \\
\text { 品 } \\
\bar{\theta}\end{array}$ & 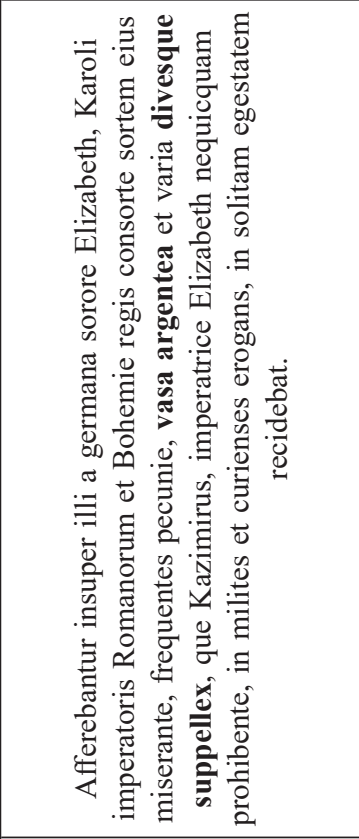 & 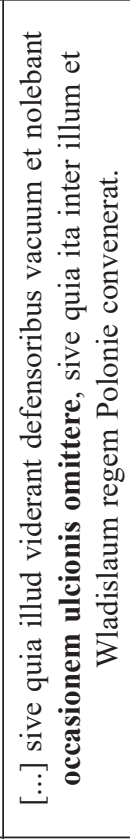 & 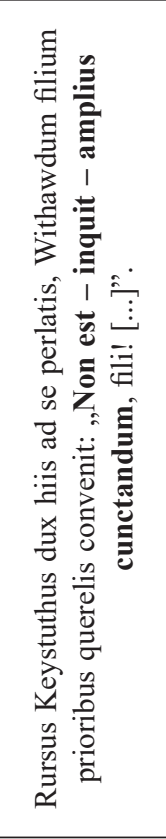 & 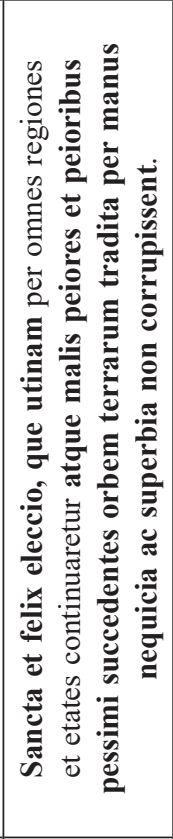 & 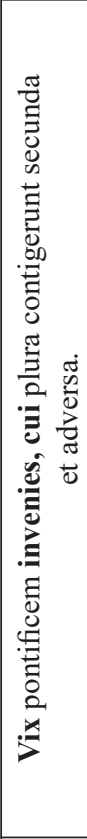 & 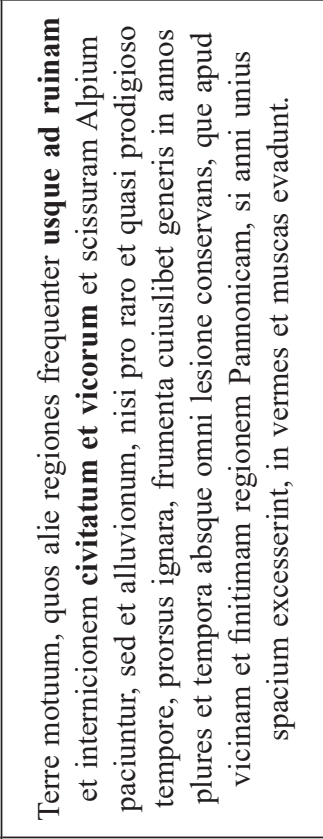 & 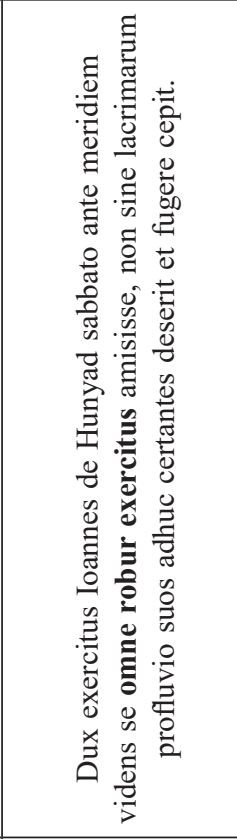 \\
\hline & 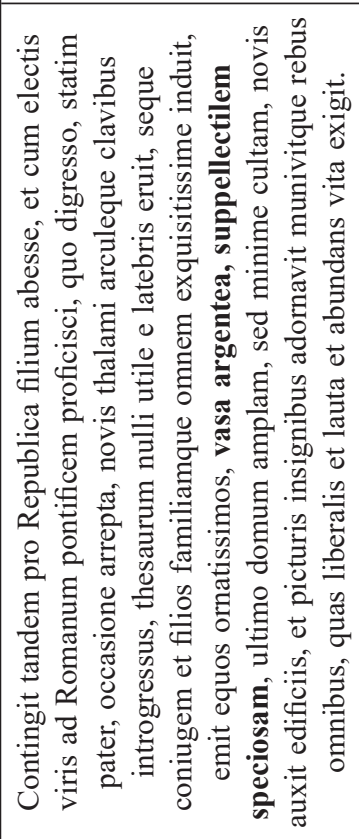 & 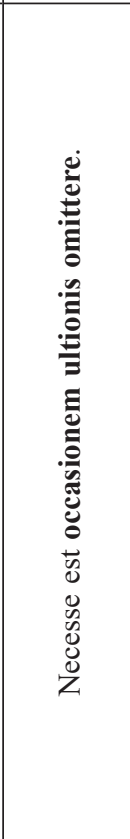 & 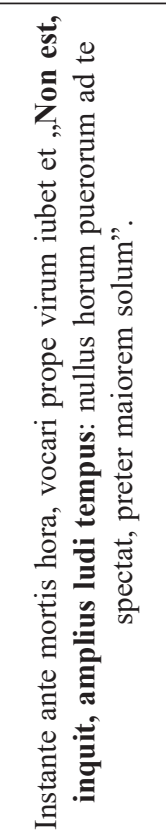 & 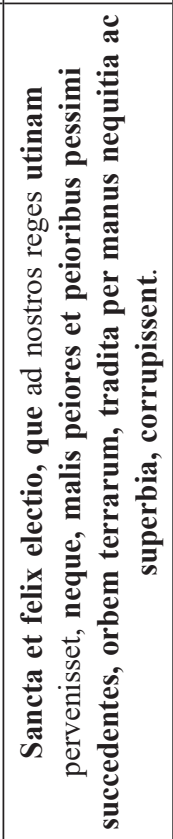 & 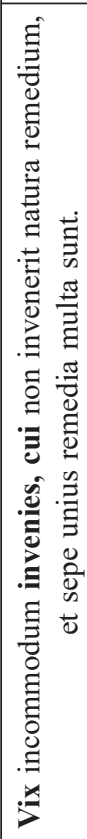 & 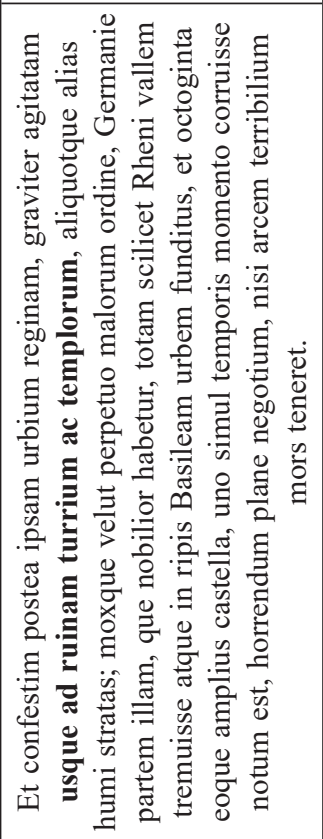 & 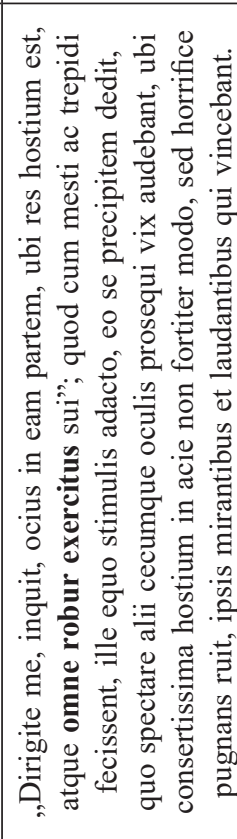 \\
\hline 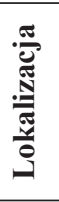 & 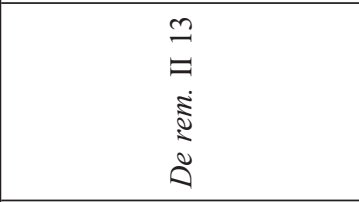 & 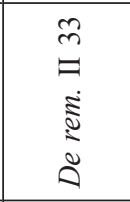 & 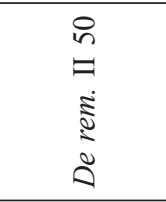 & 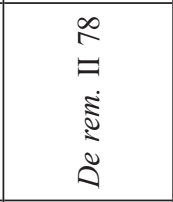 & 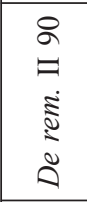 & 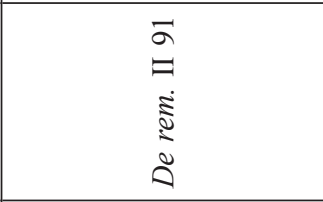 & 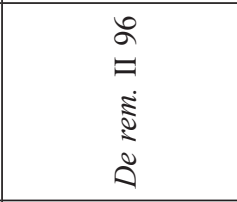 \\
\hline$\dot{\Xi}$ & $\therefore$ & $\dot{\infty}$ & $\sigma^{\circ}$ & $\stackrel{\dot{0}}{ }$ & $\dot{=}$ & $\stackrel{\sim}{\sim}$ & $\dot{\vec{g}}$ \\
\hline
\end{tabular}




\begin{tabular}{|c|c|c|c|c|c|c|c|}
\hline 焉 & 1 & 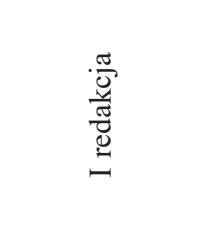 & 1 & 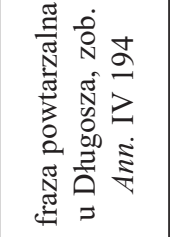 & 1 & 1 & 1 \\
\hline 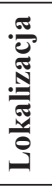 & 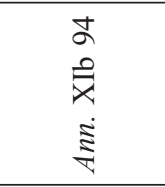 & 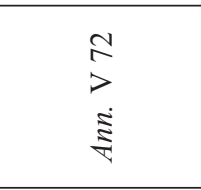 & 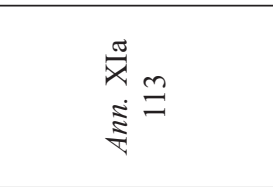 & $\begin{array}{l}\overrightarrow{\bar{x}} \\
\dot{\bar{\Sigma}}\end{array}$ & 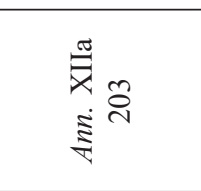 & 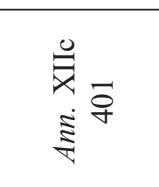 & 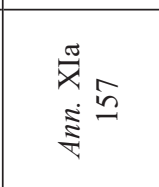 \\
\hline 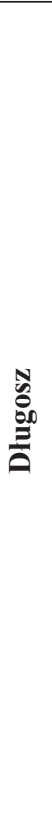 & 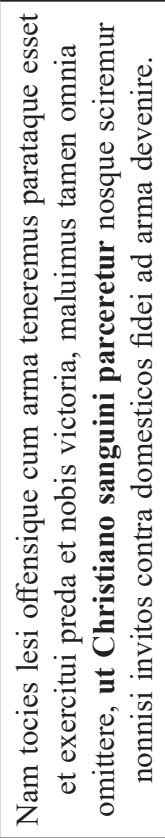 & 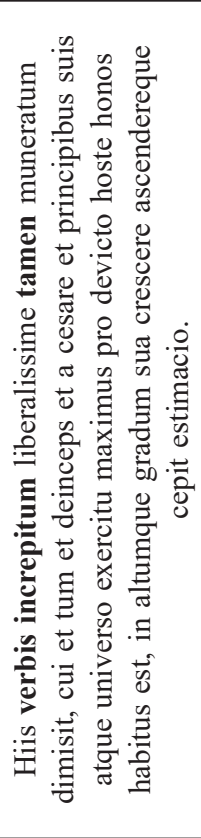 & 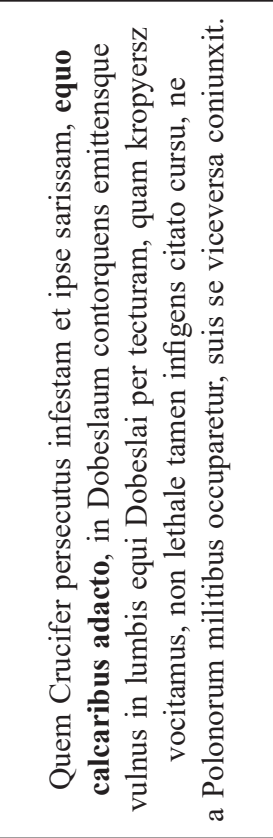 & 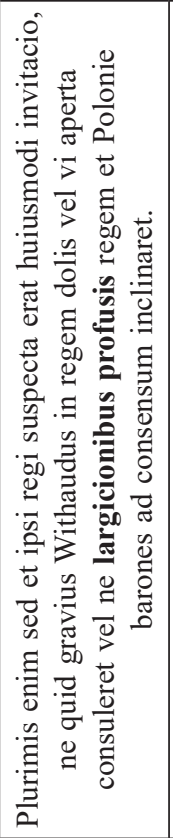 & 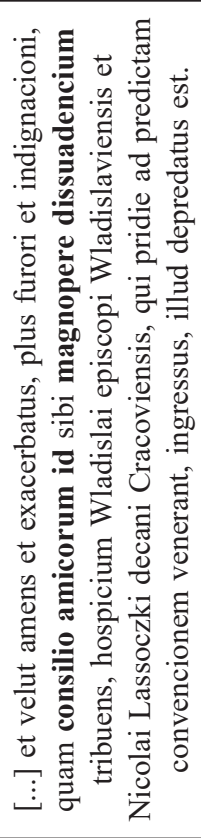 & 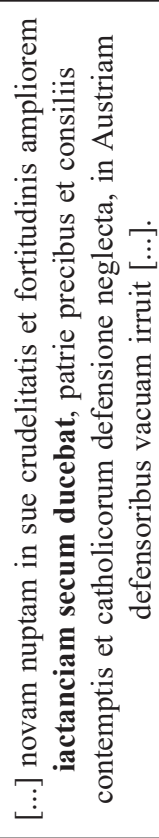 & 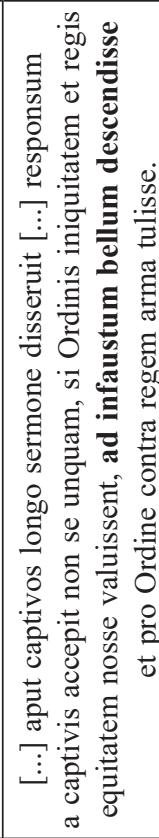 \\
\hline 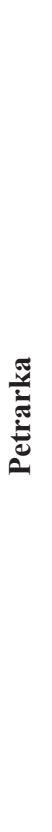 & 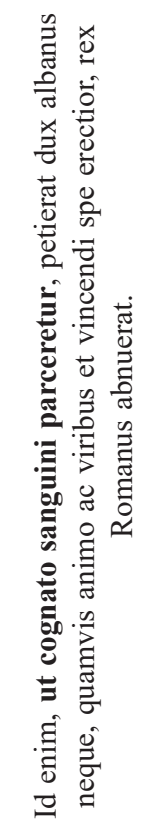 & 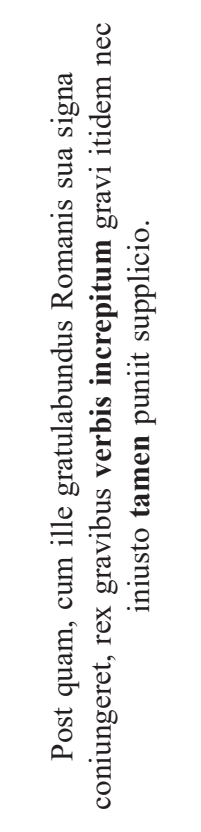 & 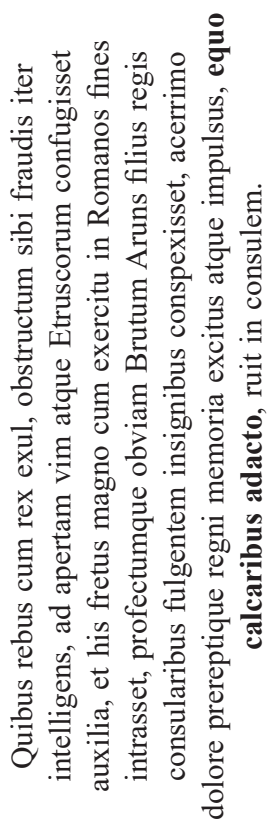 & 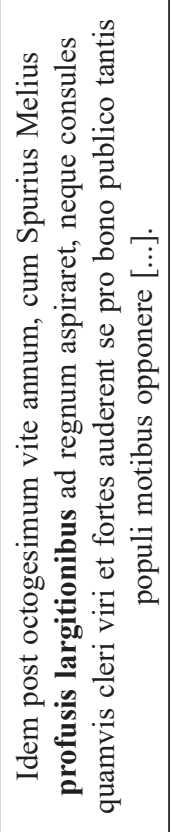 & 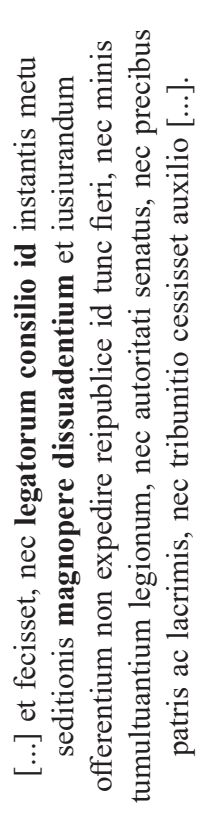 & 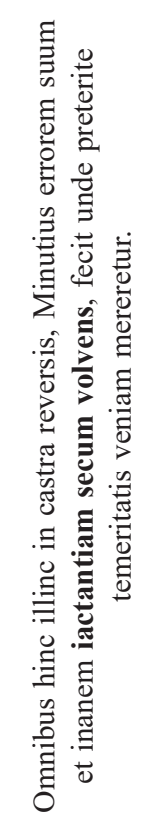 & 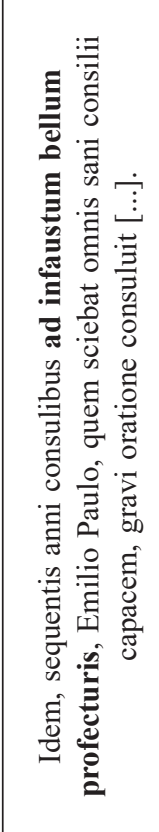 \\
\hline 苞 & 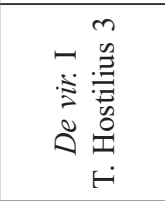 & 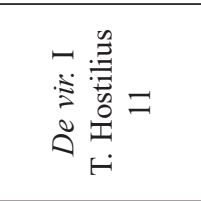 & 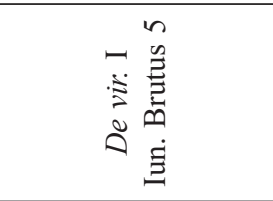 & 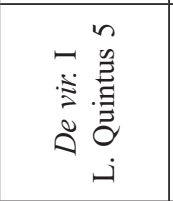 & 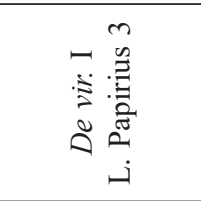 & 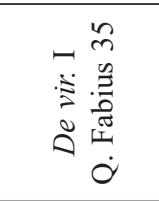 & 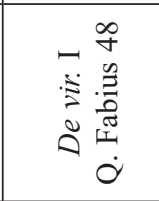 \\
\hline$\dot{\text { I }}$ & $\dot{\Xi}$ & $\ddot{n}$ & $\stackrel{\circ}{ }$ & 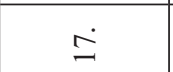 & $\stackrel{\infty}{\infty}$ & $\stackrel{\circ}{\circ}$ & $\dot{\sim}$ \\
\hline
\end{tabular}




\begin{tabular}{|c|c|c|c|c|c|c|c|}
\hline 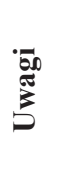 & 1 & 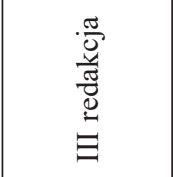 & 1 & 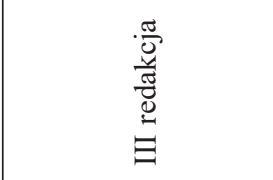 & 1 & 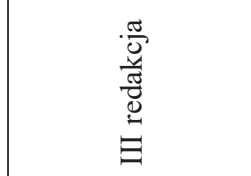 & $\begin{array}{l}\frac{\pi}{0} \\
\frac{\pi}{\pi} \\
\frac{\pi}{0} \\
=\end{array}$ \\
\hline 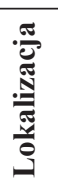 & 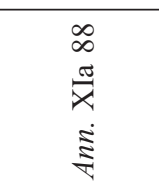 & $\begin{array}{l}\text { m } \\
\text { 日 } \\
\text { 妾 }\end{array}$ & 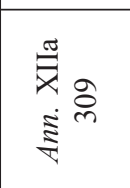 & \begin{tabular}{l}
$\infty$ \\
$\Xi$ \\
$\vdots$ \\
\multirow{2}{*}{}
\end{tabular} & 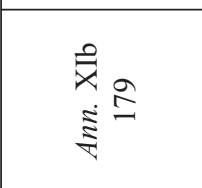 & 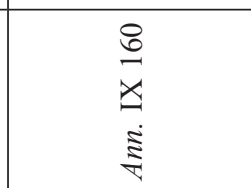 & 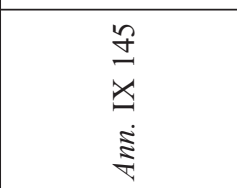 \\
\hline 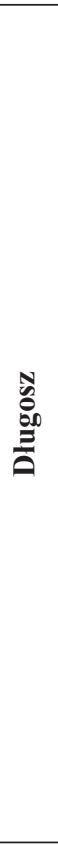 & 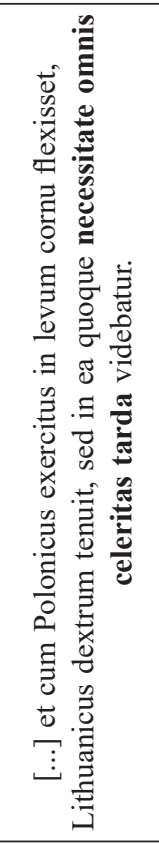 & 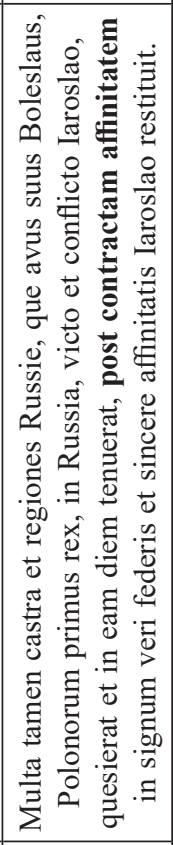 & 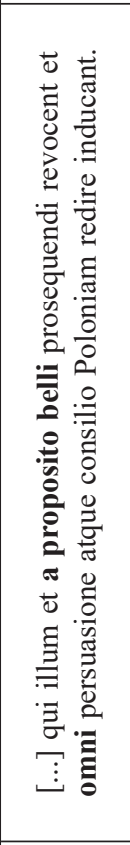 & 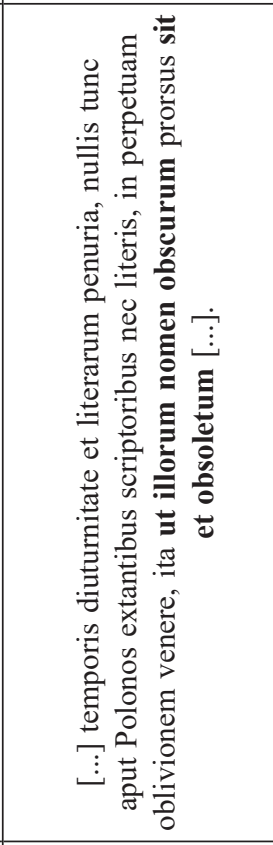 & 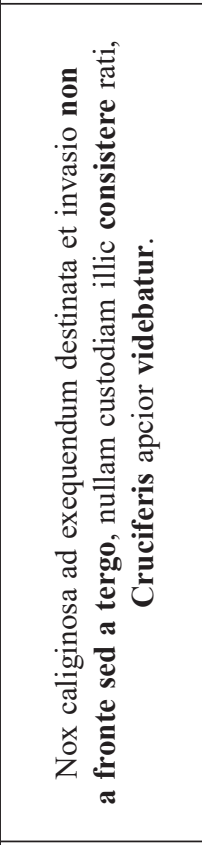 & 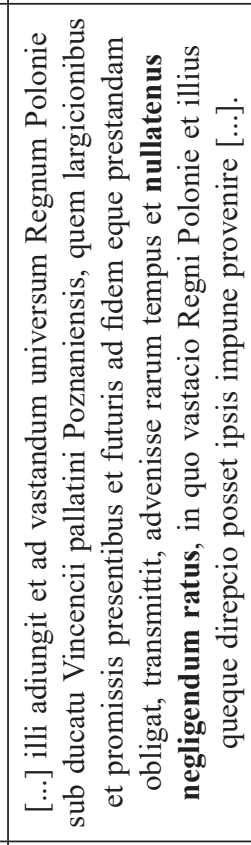 & 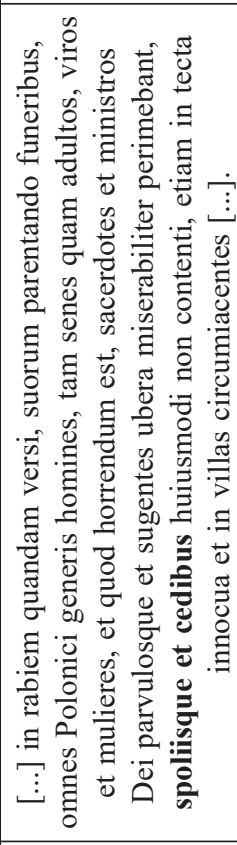 \\
\hline 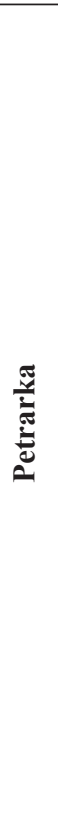 & 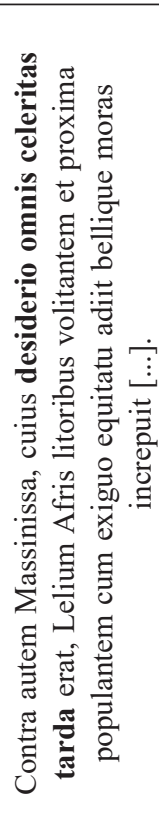 & 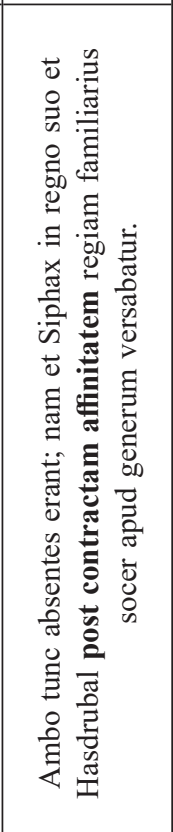 & 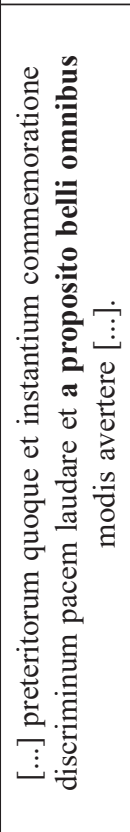 & 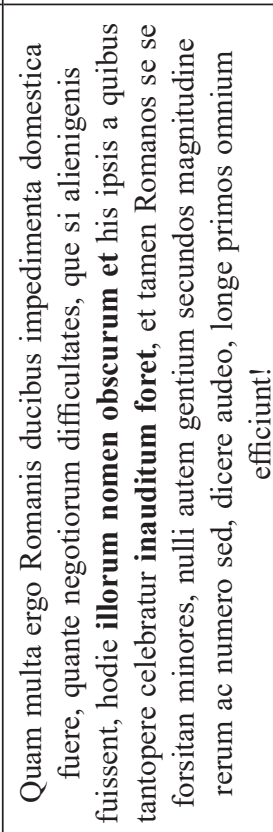 & 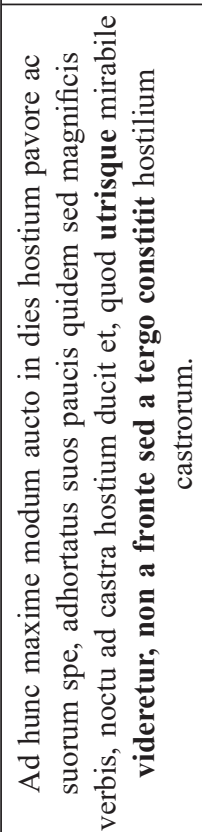 & 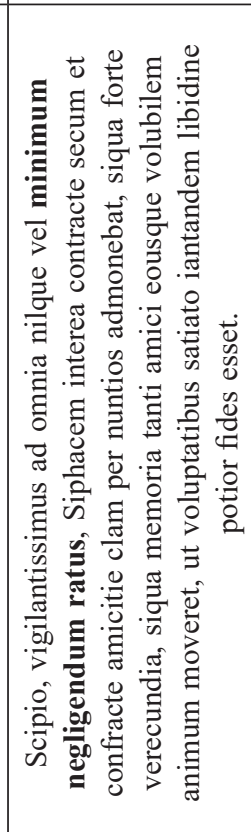 & 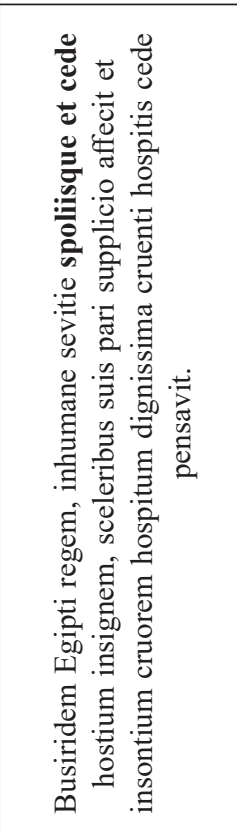 \\
\hline 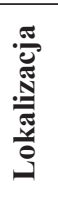 & 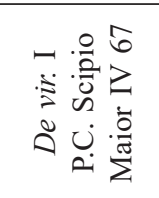 & 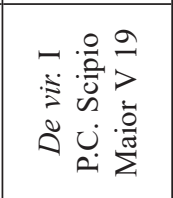 & 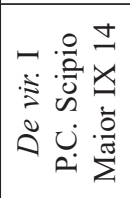 & 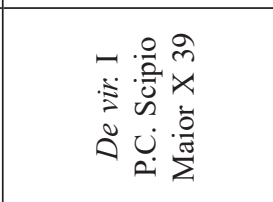 & 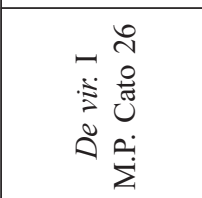 & 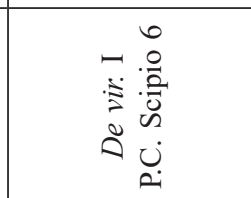 & 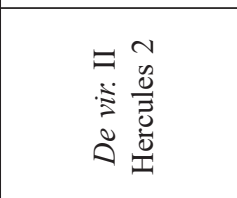 \\
\hline$\dot{\Xi}$ & $\dot{\vec{N}}$ & ત̇ & $\dot{\vec{\lambda}}$ & $\stackrel{\text { ป் }}{ }$ & $\ddot{n}$ & $\dot{\stackrel{N}{N}}$ & $\dot{\sim}$ \\
\hline
\end{tabular}




\begin{tabular}{|c|c|c|c|c|c|c|}
\hline $\begin{array}{l}50 \\
5 \\
5 \\
5 \\
5\end{array}$ & 1 & 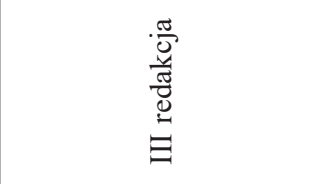 & 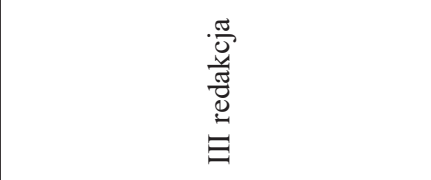 & 1 & 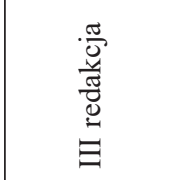 & 1 \\
\hline 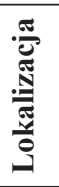 & 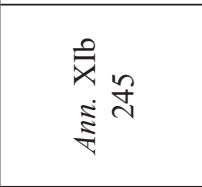 & 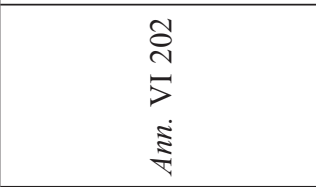 & 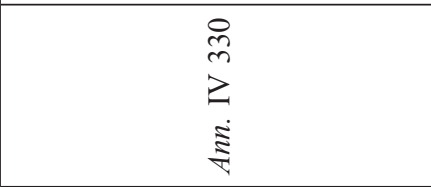 & $\begin{array}{l}\text { 齐 } \\
\text { 妾 }\end{array}$ & 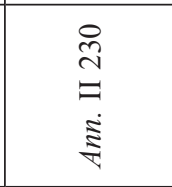 & 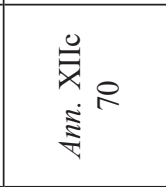 \\
\hline 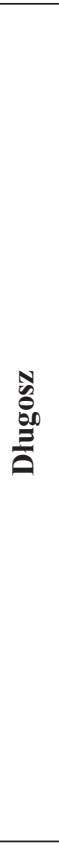 & 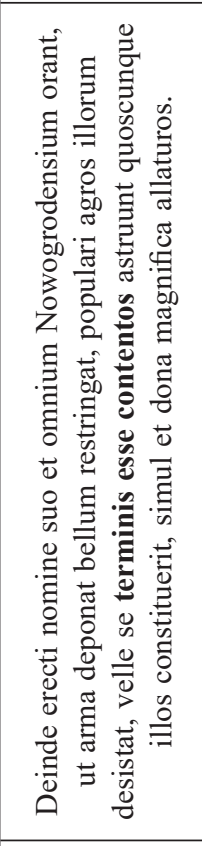 & 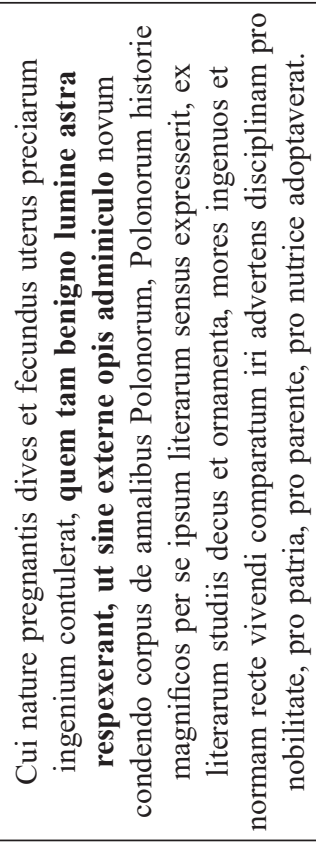 & 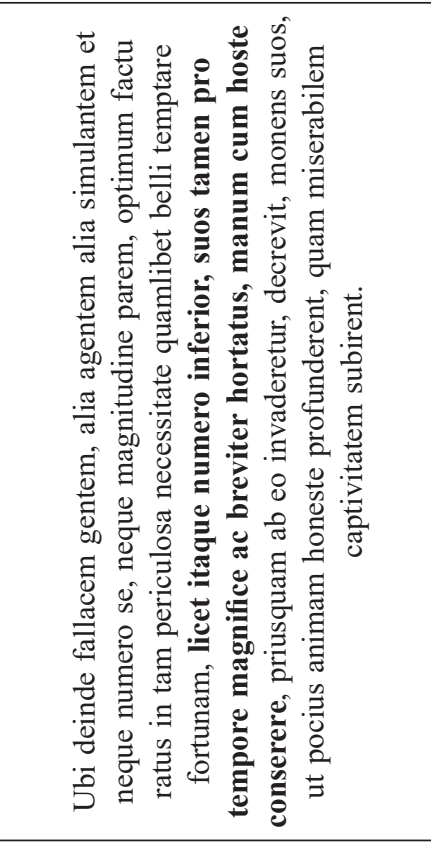 & 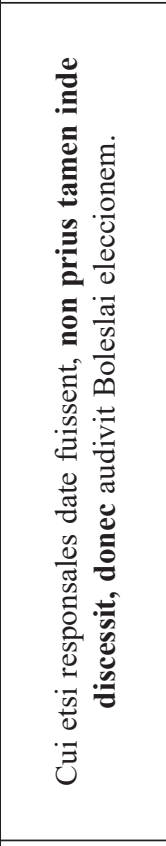 & 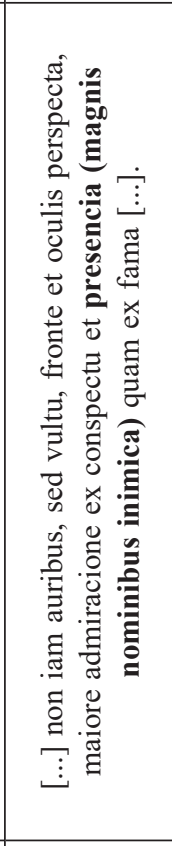 & 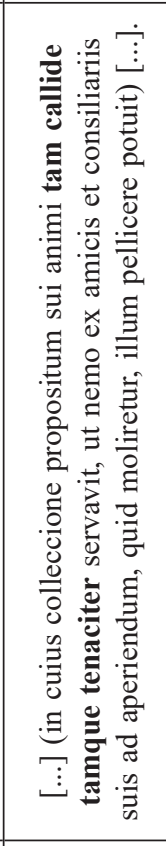 \\
\hline & 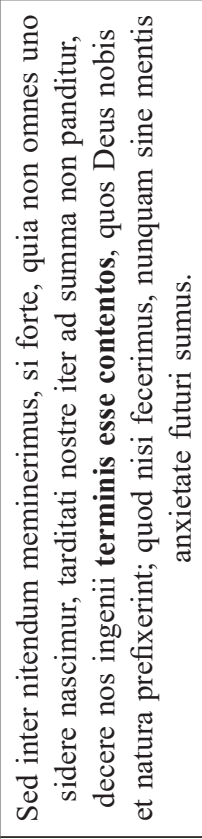 & 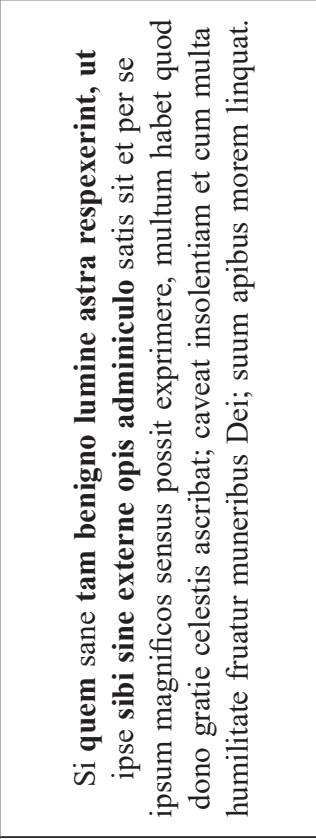 & 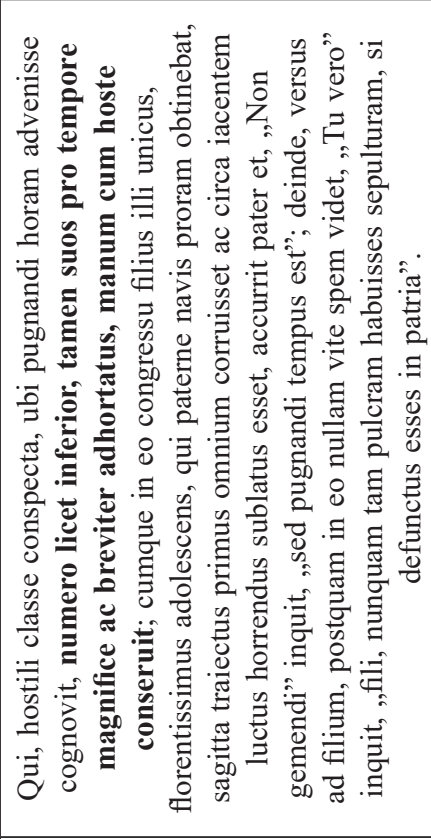 & 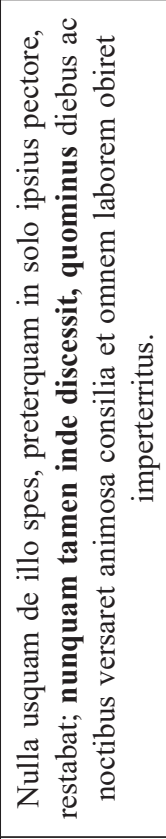 & 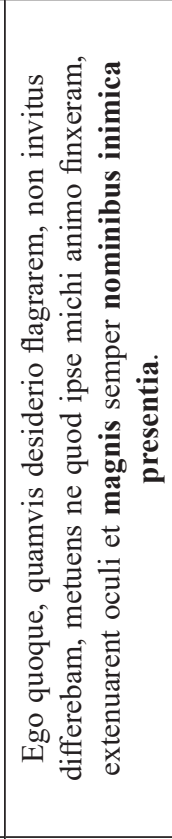 & 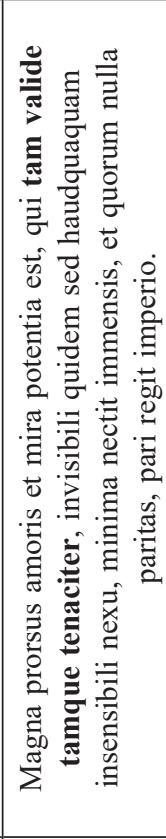 \\
\hline 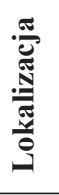 & 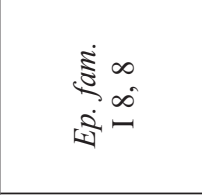 & 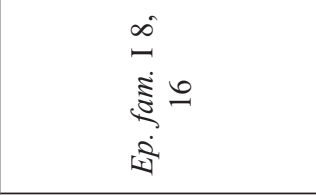 & $\begin{array}{l}= \\
\underbrace{\dot{\Sigma}} \infty \\
\text { जी } \\
\text { in }\end{array}$ & 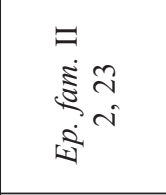 & 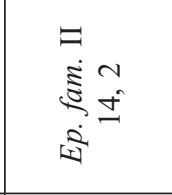 & 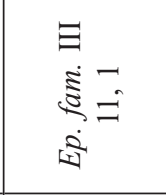 \\
\hline$\dot{\Xi}$ & $\stackrel{\infty}{\sim}$ & $\stackrel{\mathrm{i}}{0}$ & $\dot{\ominus}$ & $\dot{m}$ & लें & $\dot{m}$ \\
\hline
\end{tabular}




\begin{tabular}{|c|c|c|c|c|c|c|c|c|c|}
\hline 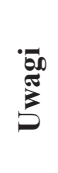 & 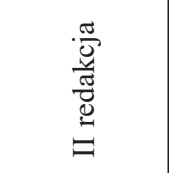 & 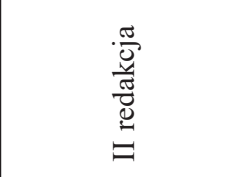 & 1 & 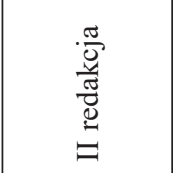 & 1 & 1 & 1 & 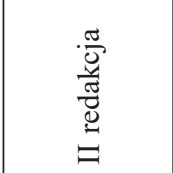 & 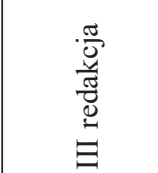 \\
\hline 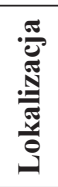 & $\begin{array}{l}a \\
\Omega \\
z \\
\vdots \\
\vdots \\
\vdots\end{array}$ & 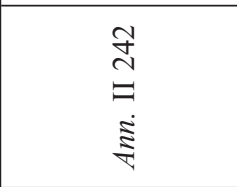 & 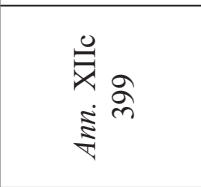 & $\begin{array}{l}\stackrel{\text { సे }}{\Xi} \\
\stackrel{\Xi}{\Xi}\end{array}$ & 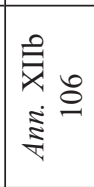 & $\begin{array}{l}\overrightarrow{\text { च }} \\
\text { ङे ते }\end{array}$ & $\begin{array}{l}\stackrel{\pi}{x} n \\
\tilde{n} \\
\dot{\Sigma}\end{array}$ & $\begin{array}{l}\vec{\sim} \\
\ddot{v} \\
\dot{\Sigma} \\
\dot{y}\end{array}$ & $\begin{array}{l}\infty \\
\stackrel{\infty}{Z} \\
\vdots \\
\dot{\Sigma}\end{array}$ \\
\hline 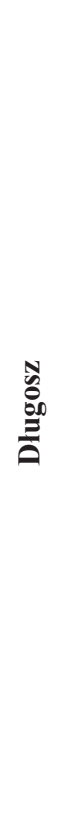 & 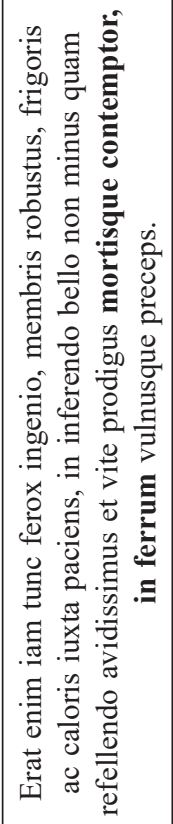 & 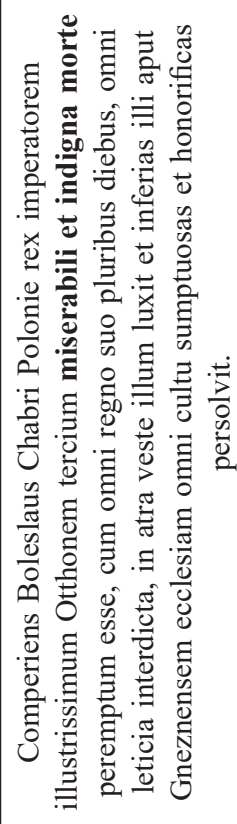 & 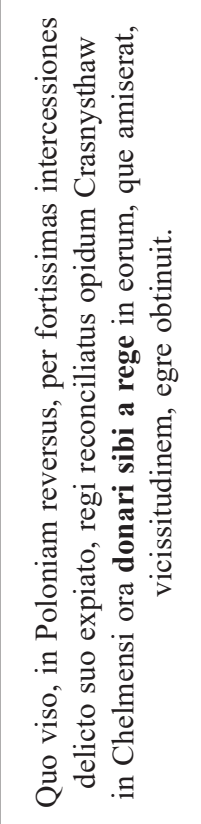 & 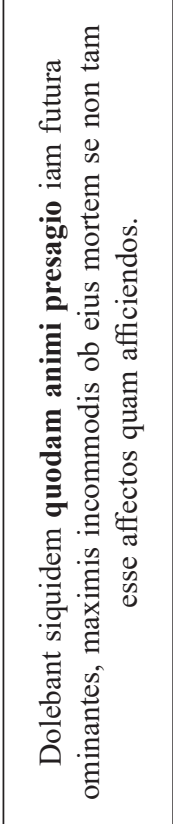 & 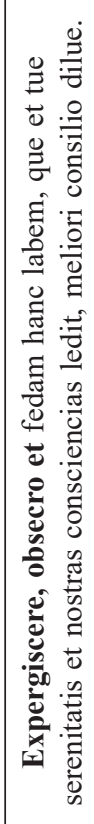 & 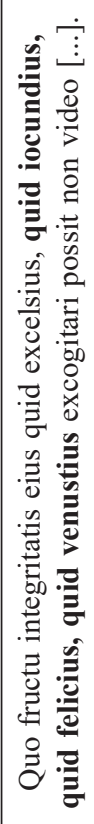 & 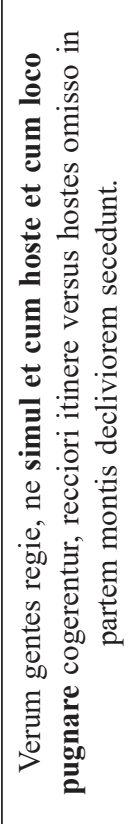 & 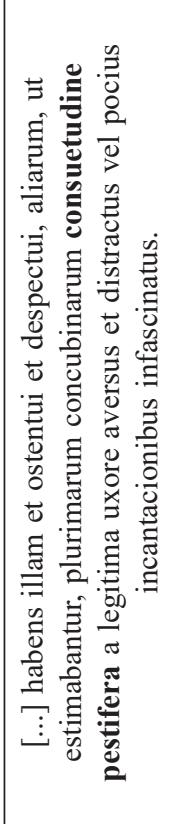 & 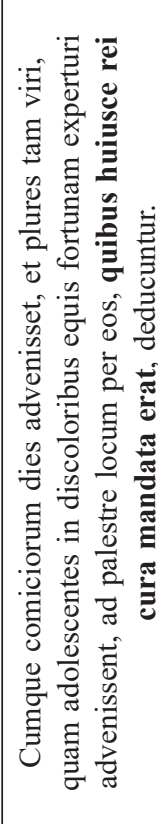 \\
\hline & 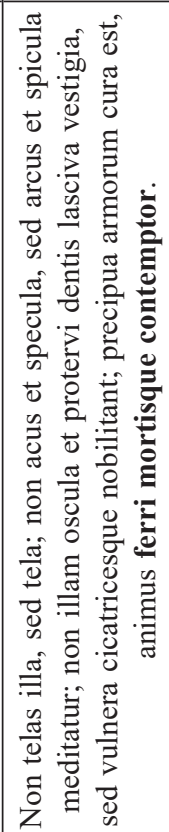 & 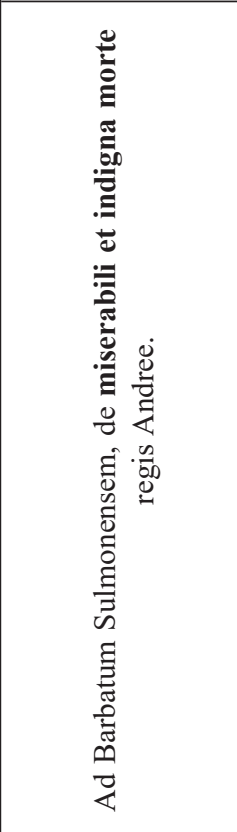 & 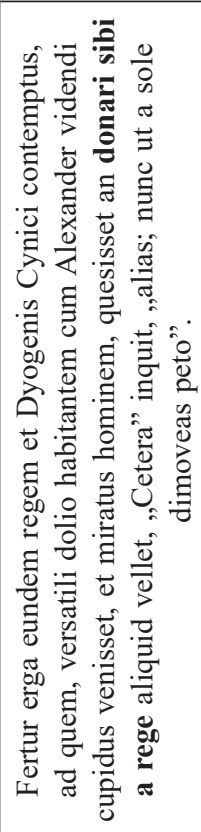 & 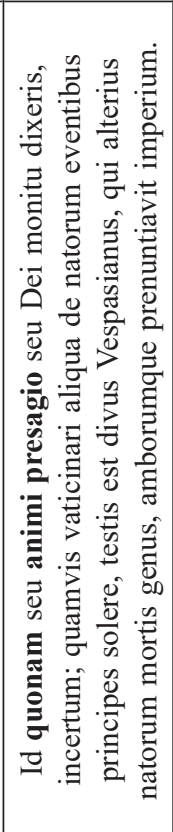 & 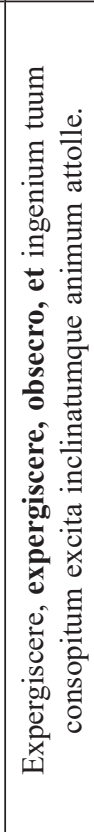 & 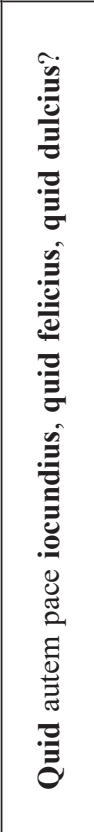 & 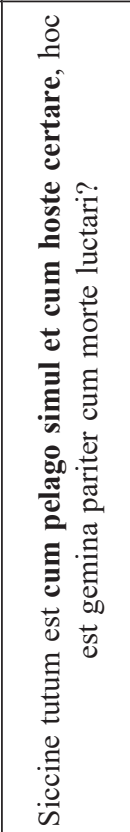 & 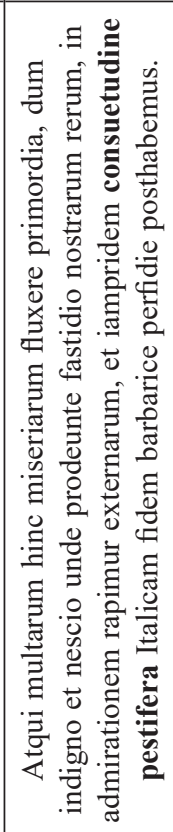 & 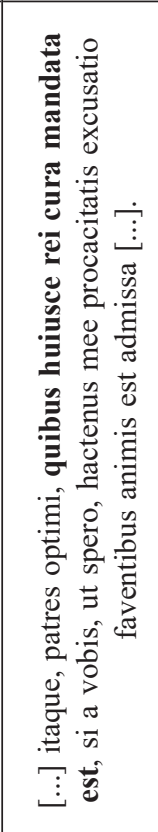 \\
\hline 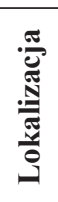 & 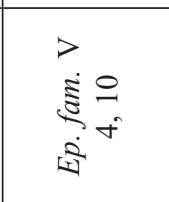 & $\begin{array}{l}n \\
5 \\
5 \\
5 \\
0 \\
0\end{array}$ & $\begin{array}{l}> \\
\dot{3} 0 \\
\infty \\
0 \\
0\end{array}$ & 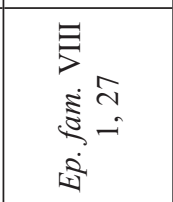 & 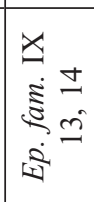 & 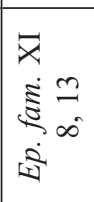 & $\begin{array}{l}\bar{x} \\
\dot{\vec{s}} \pm \\
\dot{0} \\
\text { ज्ञ }\end{array}$ & 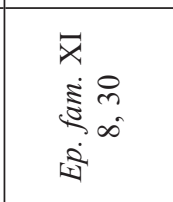 & 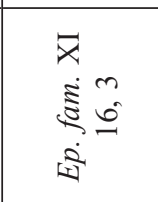 \\
\hline$\dot{\Delta}$ & $\dot{m}$ & $\dot{m}$ & $\dot{n}$ & $\dot{m}$ & $\underset{m}{\infty}$ & $\dot{m}$ & $\dot{q}$ & $\dot{\gamma}$ & ร่ \\
\hline
\end{tabular}




\begin{tabular}{|c|c|c|c|c|c|c|c|}
\hline ס & 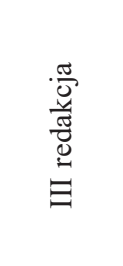 & 1 & 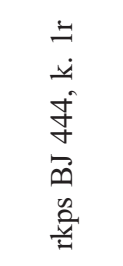 & 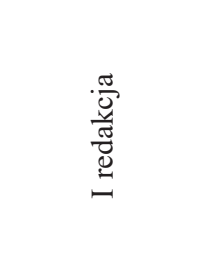 & 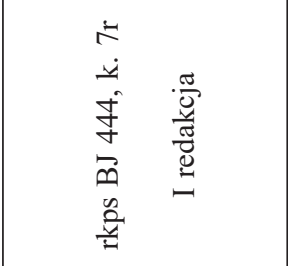 & 1 & 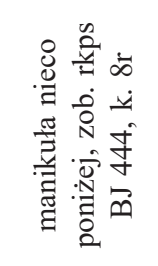 \\
\hline 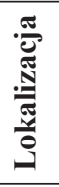 & $\begin{array}{l}\stackrel{\infty}{\cong} \\
\Xi \\
\dot{\Xi} \\
\dot{\Sigma}\end{array}$ & $\begin{array}{l}\text { 齐 } \\
\text { 章 }\end{array}$ & 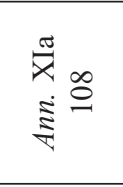 & 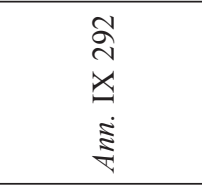 & $\begin{array}{l}\vec{n} \\
\tilde{n} \\
u \\
\vdots \\
\vdots\end{array}$ & 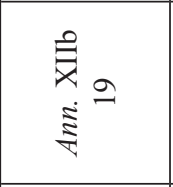 & 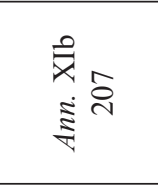 \\
\hline 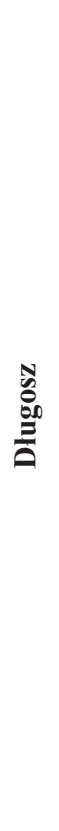 & 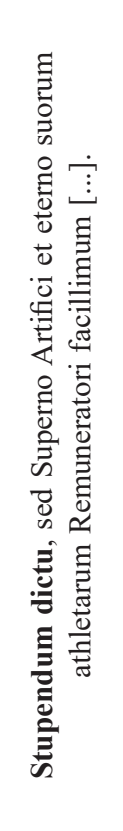 & 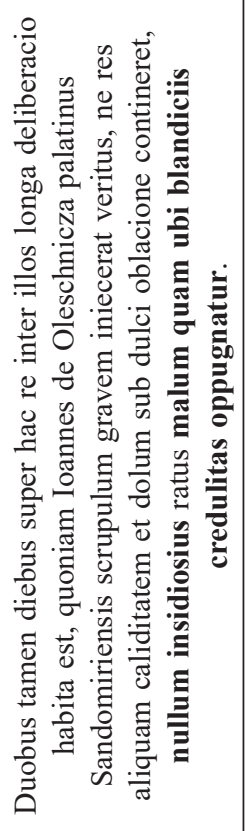 & 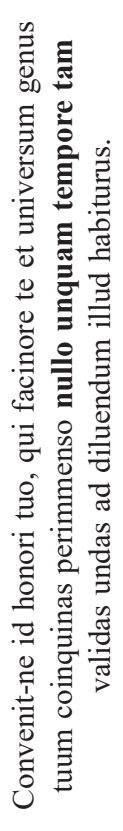 & 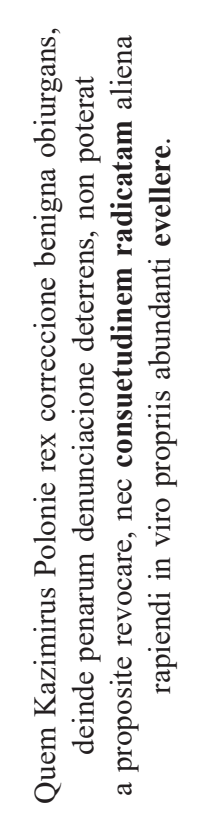 & 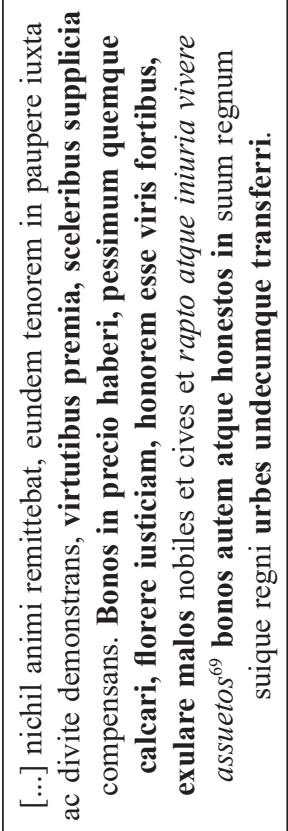 & 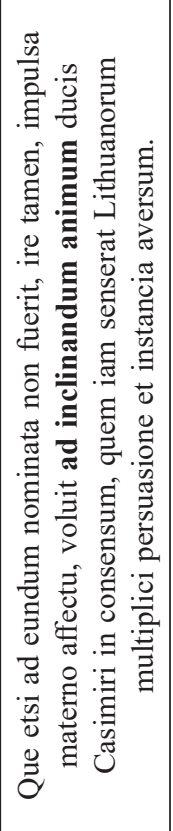 & 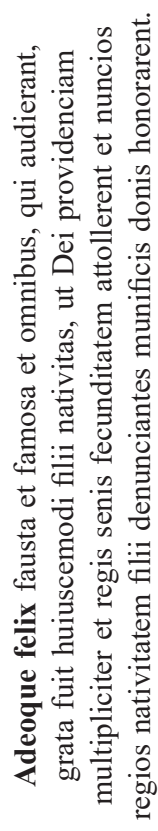 \\
\hline & 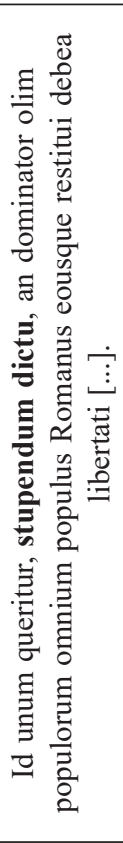 & 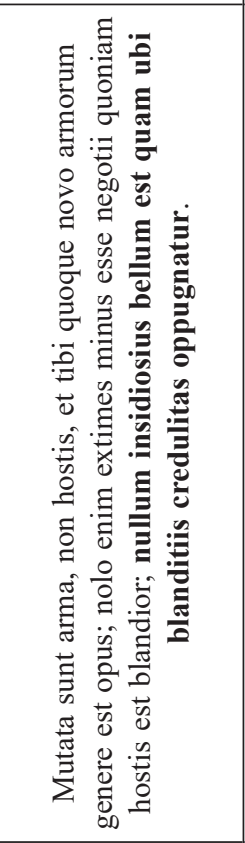 & 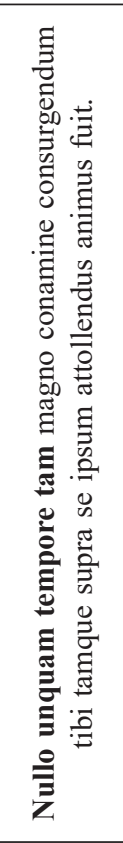 & 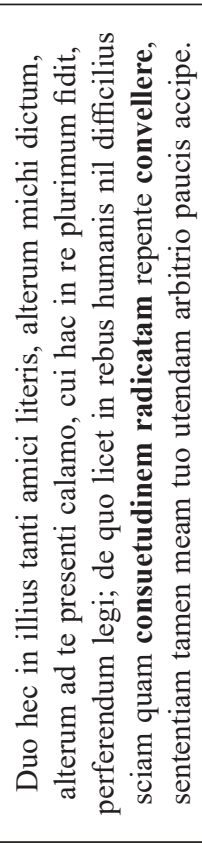 & 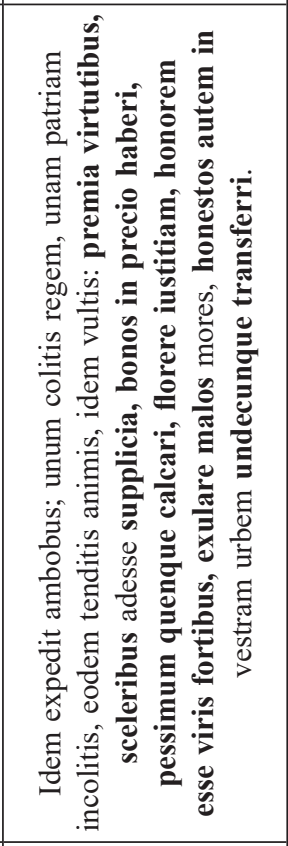 & 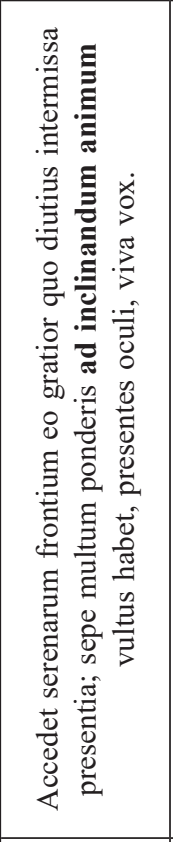 & 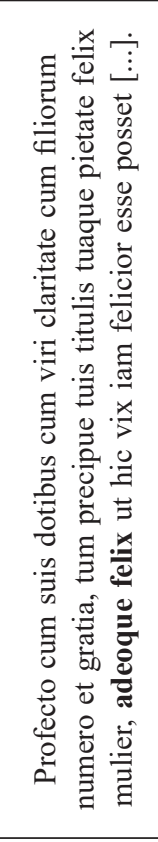 \\
\hline $\begin{array}{l}\frac{\pi}{\tilde{\pi}} \\
\frac{\sqrt[\pi]{\pi}}{\pi} \\
\frac{\pi}{0} \\
\end{array}$ & $\begin{array}{l}\bar{x} \\
\dot{\bar{s}}= \\
0 \\
0 \\
0\end{array}$ & 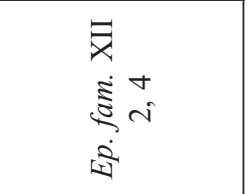 & $\begin{array}{l}\bar{x} \\
\dot{\vec{s}} a \\
\text { iी }\end{array}$ & $\begin{array}{l}\vec{x} \\
\dot{\bar{y}}+ \\
\dot{0} \\
\text { जी }\end{array}$ & 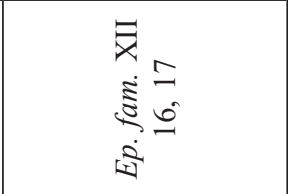 & 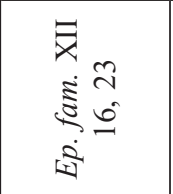 & 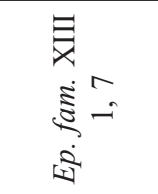 \\
\hline$\dot{\grave{I}}$ & $\dot{F}$ & $\stackrel{+}{+}$ & $\ddot{q}$ & $\dot{\mathscr{q}}$ & $\dot{\gamma}$ & $\stackrel{\infty}{+}$ & $\dot{q}$ \\
\hline
\end{tabular}




\begin{tabular}{|c|c|c|c|c|c|c|c|}
\hline 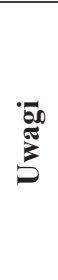 & 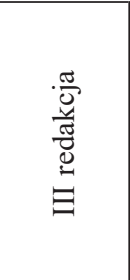 & 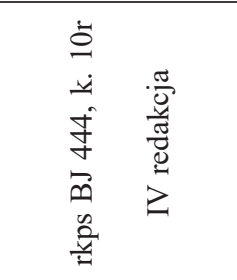 & 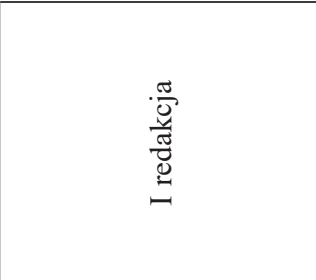 & 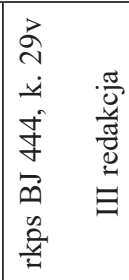 & 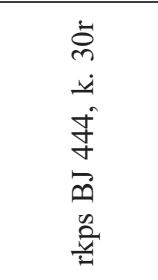 & 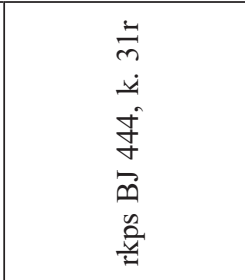 & 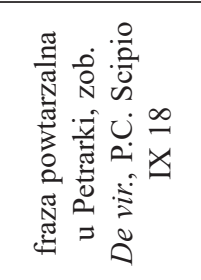 \\
\hline $\begin{array}{l}\frac{\pi}{\pi} \\
\frac{\pi}{\pi} \\
\frac{\pi}{\pi} \\
\frac{\pi}{0} \\
\frac{\pi}{0}\end{array}$ & $\begin{array}{l}\text { సे } \\
\text { इ̇ }\end{array}$ & $\begin{array}{l}\stackrel{n}{\beth} \\
\vdots \\
\Sigma\end{array}$ & $\begin{array}{l}5 \\
\stackrel{5}{5} \\
5 \\
\vdots \\
\vdots\end{array}$ & $\begin{array}{l}\cong \\
\Xi \\
\Xi \\
\vdots \\
\vdots\end{array}$ & 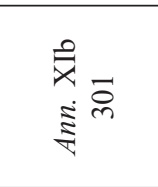 & $\begin{array}{l}\text { 気 } \\
\text { 妾 }\end{array}$ & 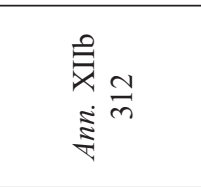 \\
\hline & 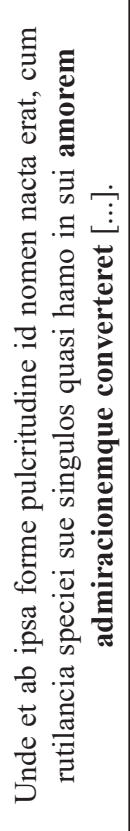 & 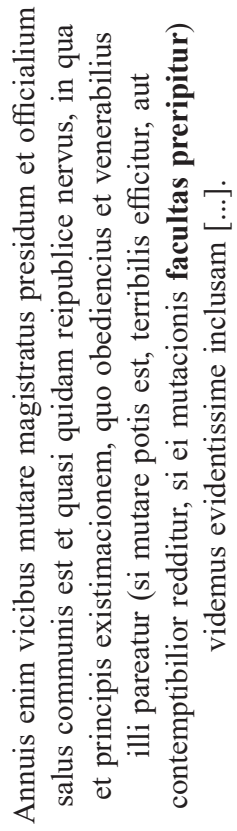 & 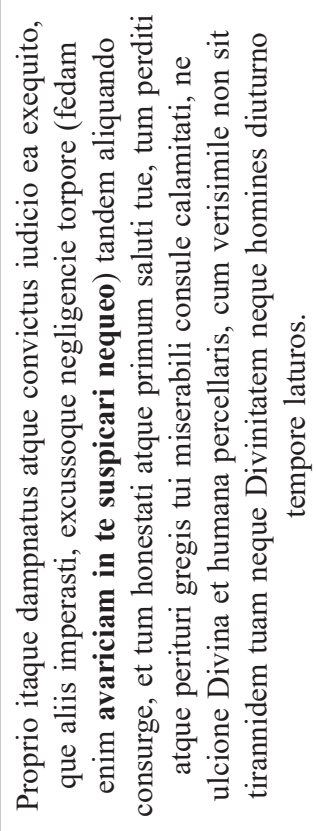 & 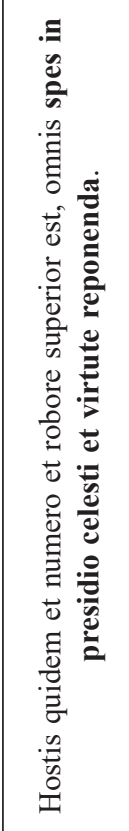 & 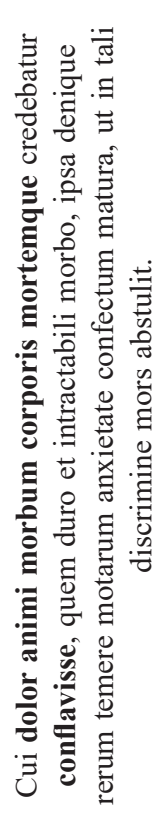 & 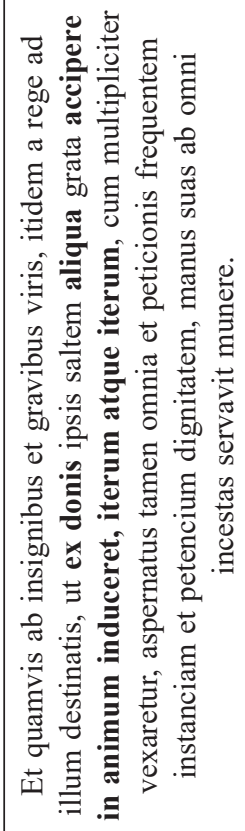 & 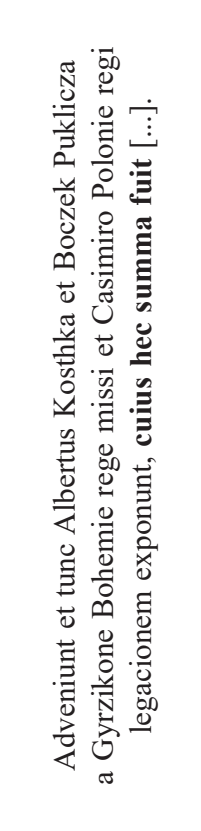 \\
\hline 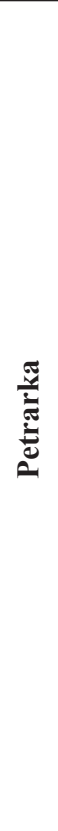 & 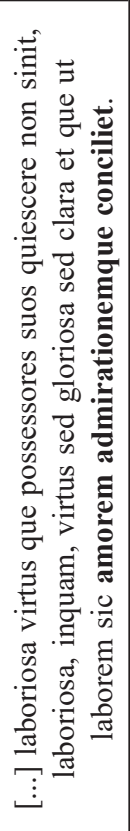 & 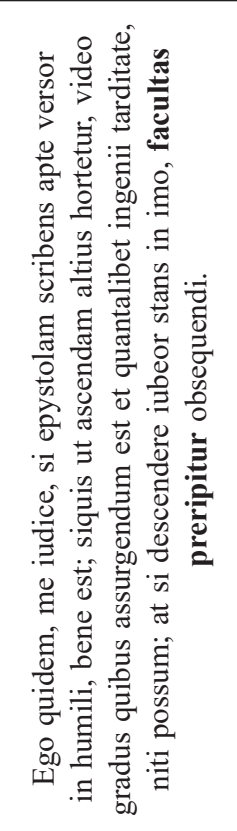 & 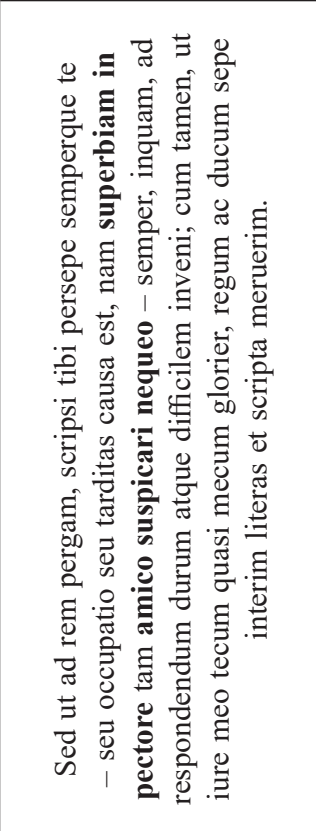 & 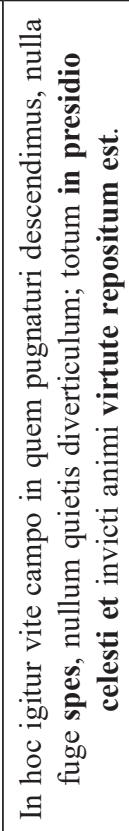 & 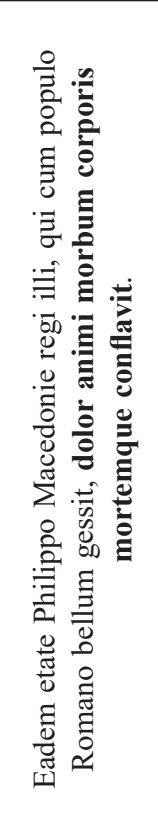 & 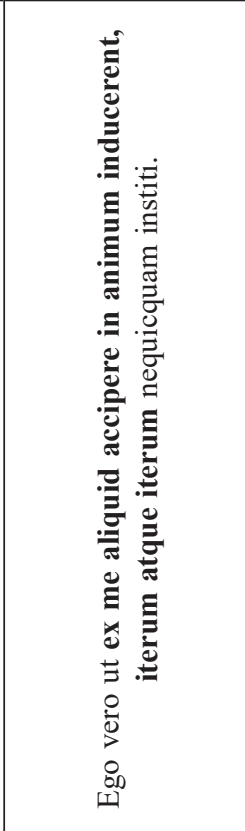 & 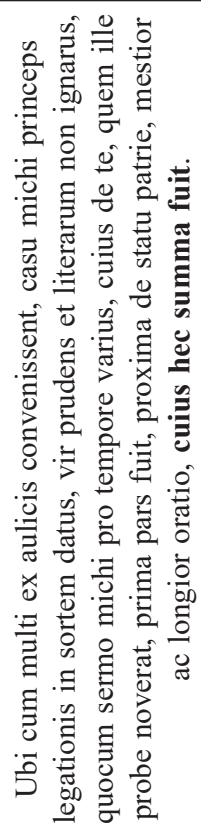 \\
\hline 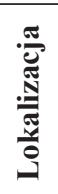 & 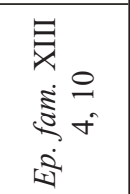 & 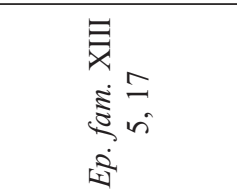 & 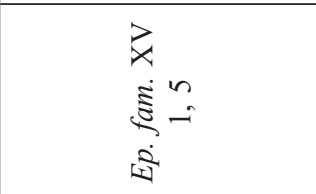 & 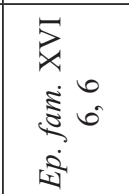 & 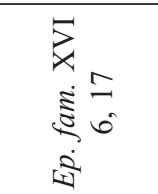 & 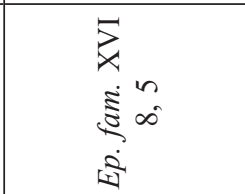 & 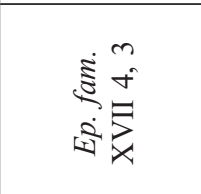 \\
\hline$\dot{\dot{\lambda}}$ & in & $\dot{n}$ & กี & $\dot{n}$ & in & in & $\dot{n}$ \\
\hline
\end{tabular}




\begin{tabular}{|c|c|c|c|c|c|}
\hline $\begin{array}{l}50 \\
5 \\
5 \\
5 \\
5\end{array}$ & 1 & 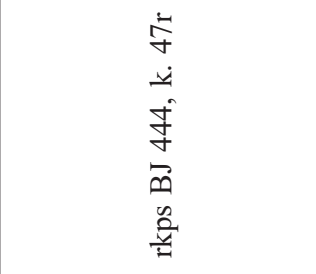 & 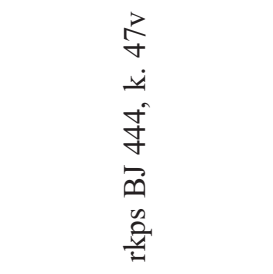 & 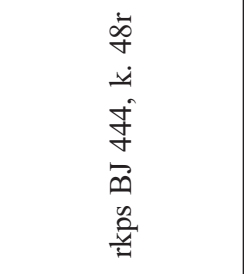 & 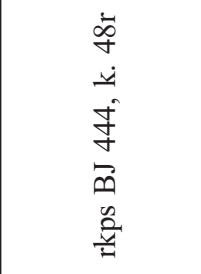 \\
\hline 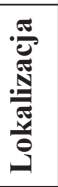 & 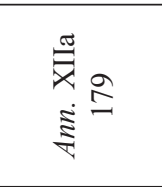 & 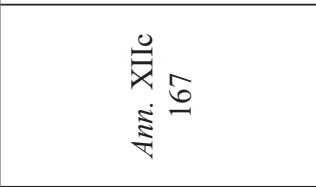 & 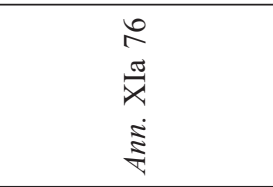 & 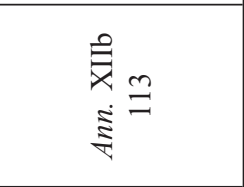 & $\begin{array}{l}\stackrel{\vec{x}}{x} \\
\stackrel{n}{\vec{\Sigma}}\end{array}$ \\
\hline 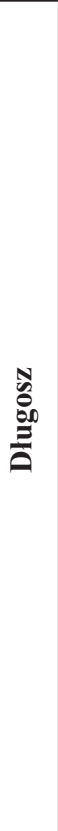 & 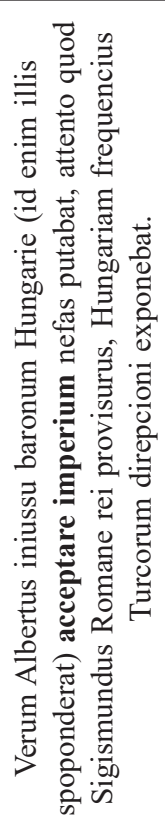 & 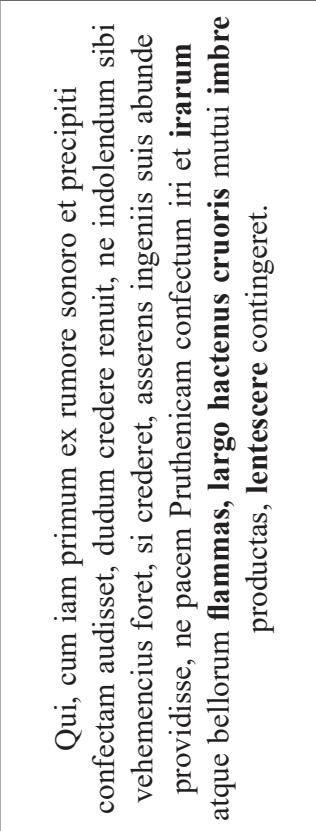 & 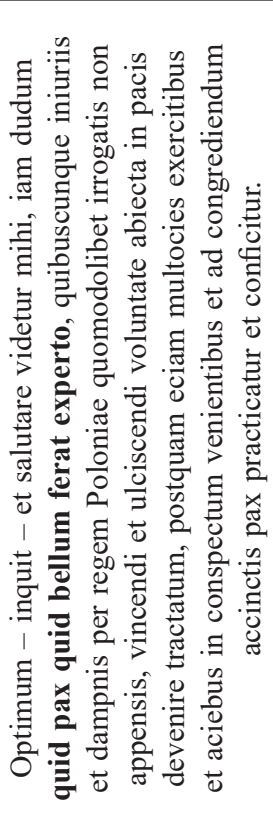 & 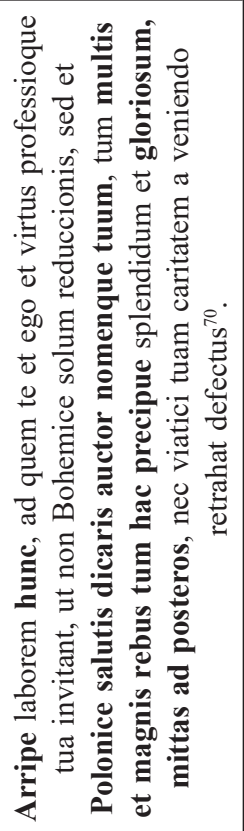 & 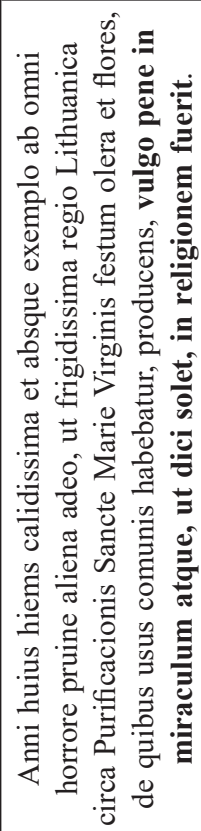 \\
\hline 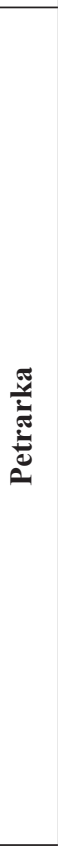 & 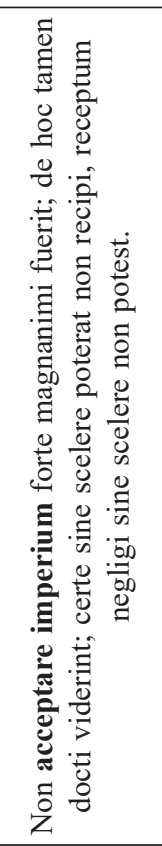 & 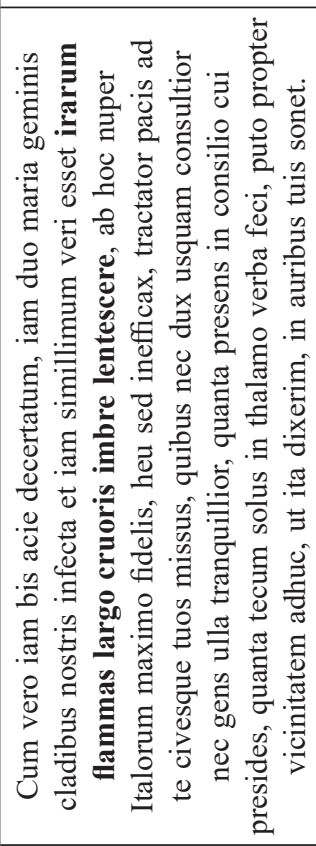 & 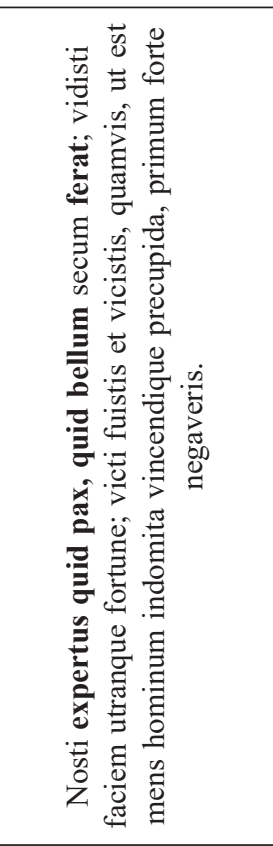 & 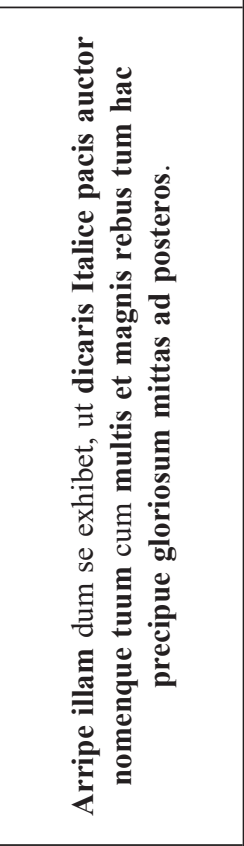 & 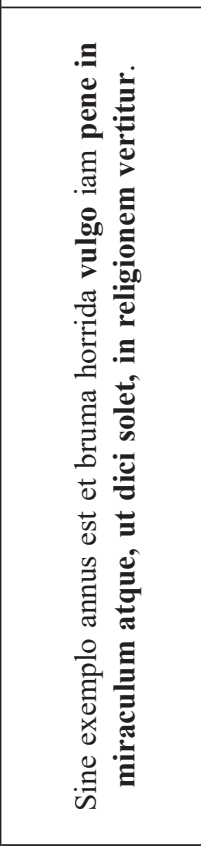 \\
\hline 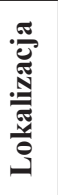 & 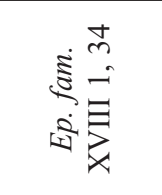 & 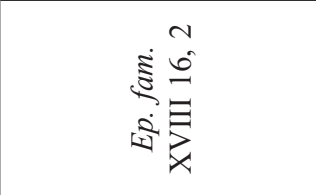 & 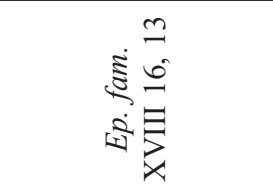 & 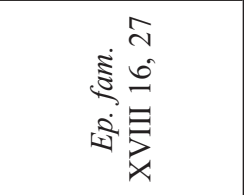 & 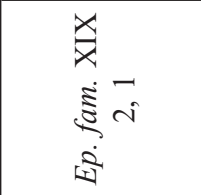 \\
\hline$\dot{\grave{I}}$ & in & $\stackrel{\infty}{n}$ & in & $\dot{8}$ & $\dot{0}$ \\
\hline
\end{tabular}




\begin{tabular}{|c|c|c|c|c|}
\hline 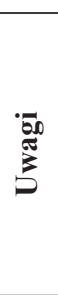 & 1 & 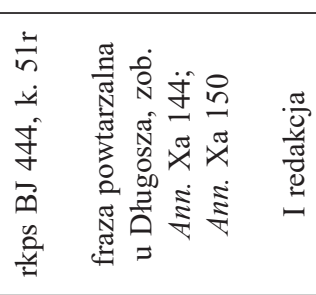 & 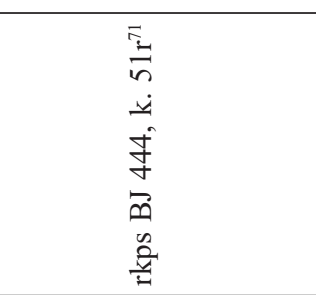 & 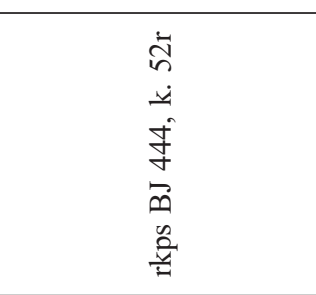 \\
\hline 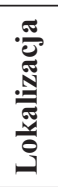 & $\begin{array}{l}\text { 齐 } \\
\text { 离 }\end{array}$ & 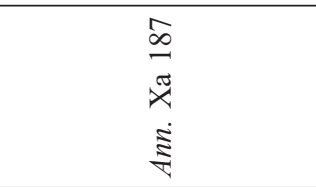 & 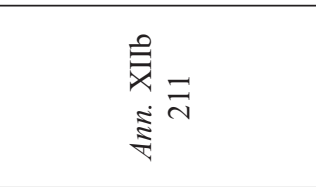 & $\begin{array}{l}\vec{x} \\
\dot{\equiv}=\end{array}$ \\
\hline 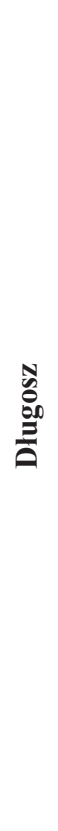 & 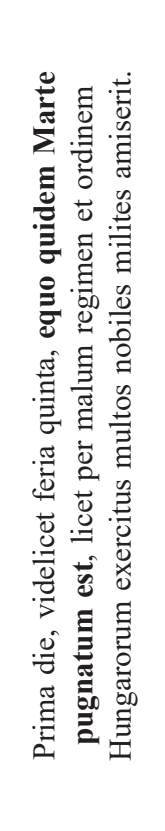 & 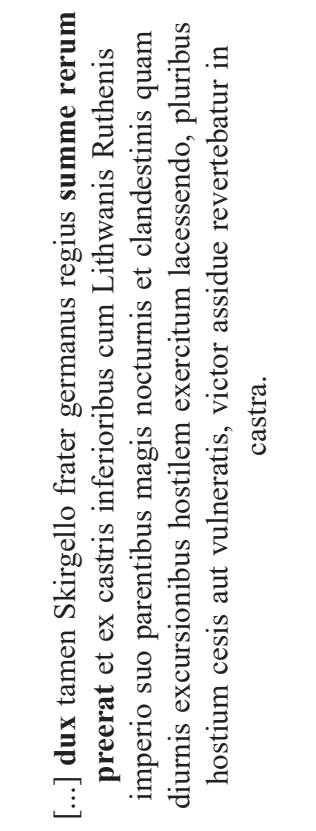 & 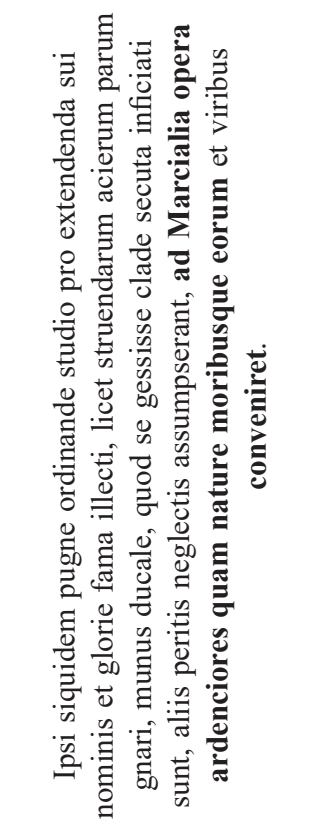 & 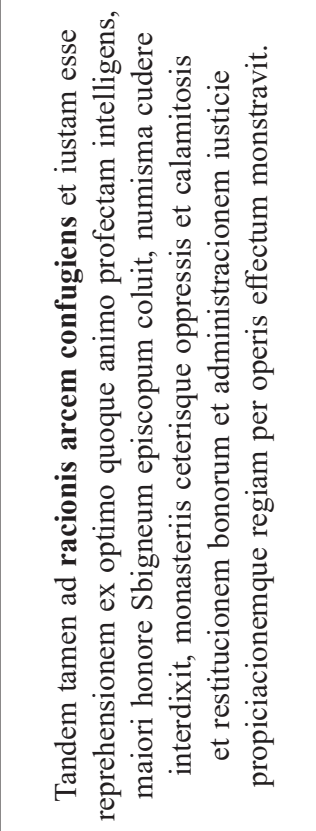 \\
\hline 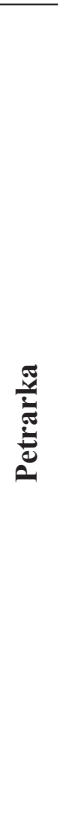 & 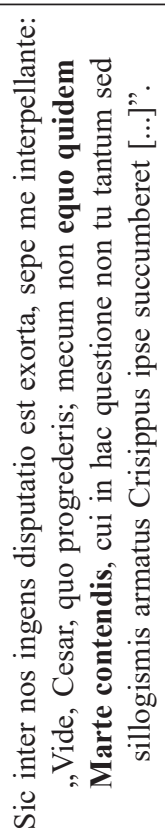 & 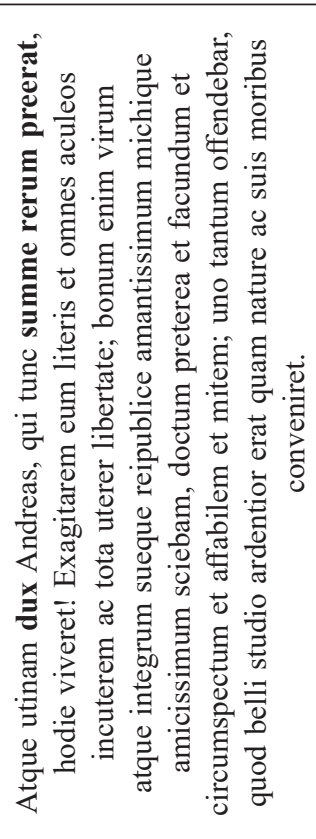 & 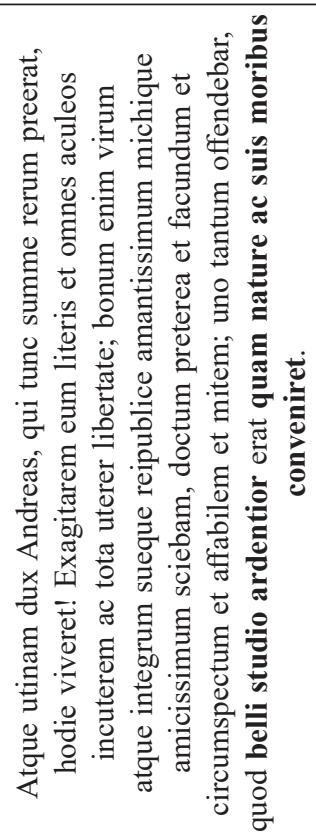 & 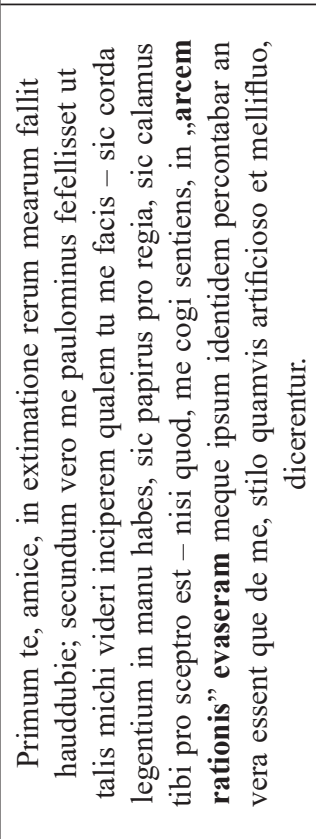 \\
\hline 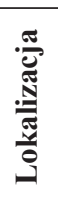 & 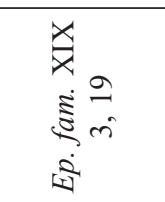 & 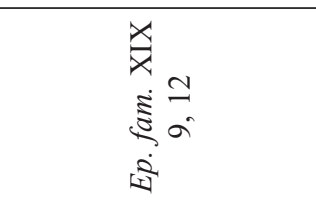 & 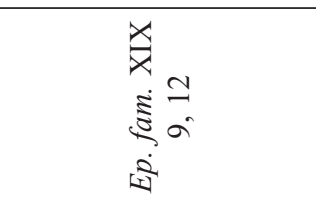 & 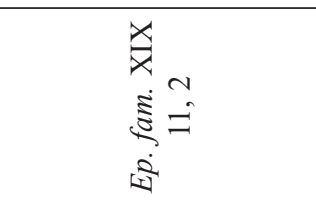 \\
\hline$\dot{\grave{z}}$ & ชิ & $\dot{6}$ & ப் & 10 \\
\hline
\end{tabular}




\begin{tabular}{|c|c|c|c|c|c|c|c|}
\hline "20 & 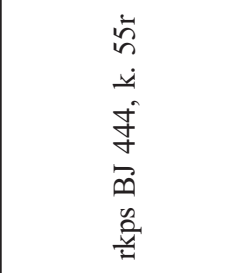 & 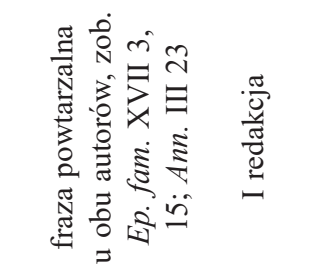 & 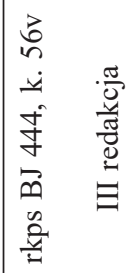 & 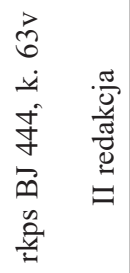 & $\begin{array}{l}\frac{\pi}{0} \\
\frac{\pi}{0} \\
\frac{\pi}{0} \\
.\end{array}$ & 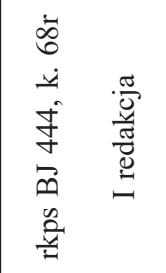 & 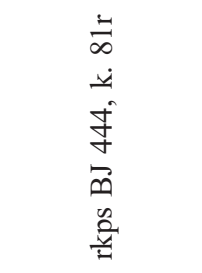 \\
\hline 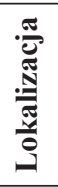 & 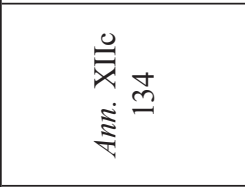 & $\begin{array}{l}8 \\
\stackrel{1}{5} \\
5 \\
\vdots\end{array}$ & 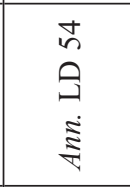 & $\begin{array}{l}\text { I } \\
\Xi \\
\Xi \\
\Xi\end{array}$ & 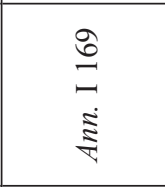 & 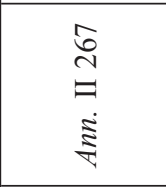 & 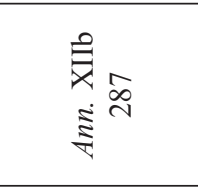 \\
\hline & 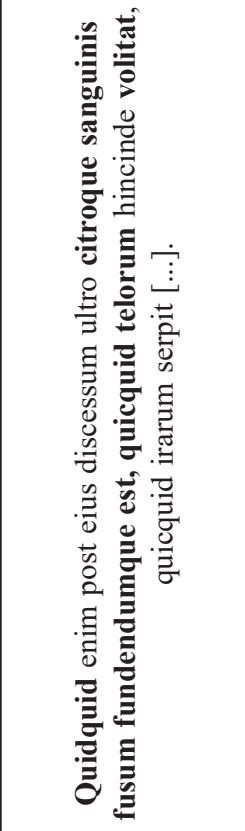 & 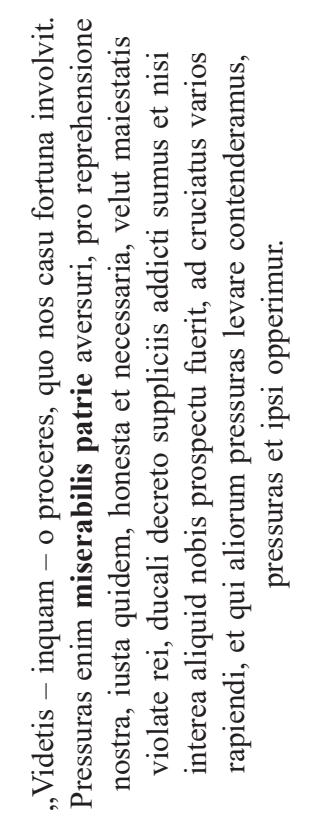 & 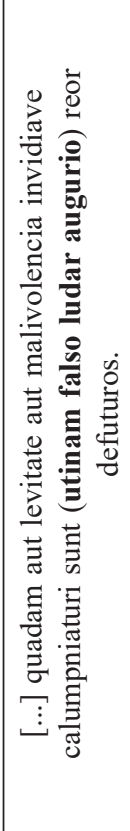 & 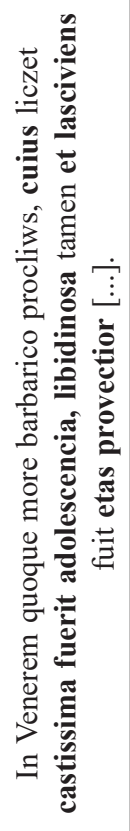 & 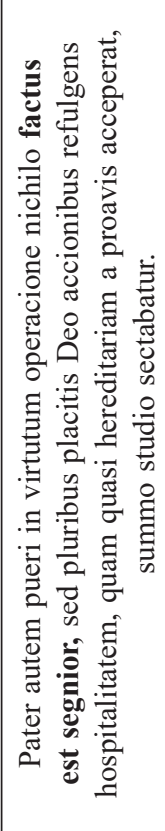 & 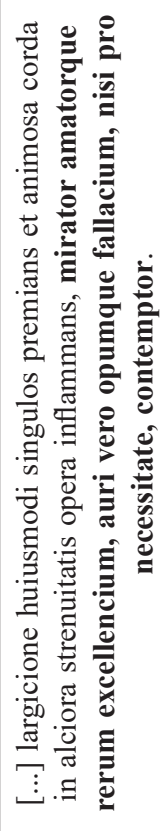 & 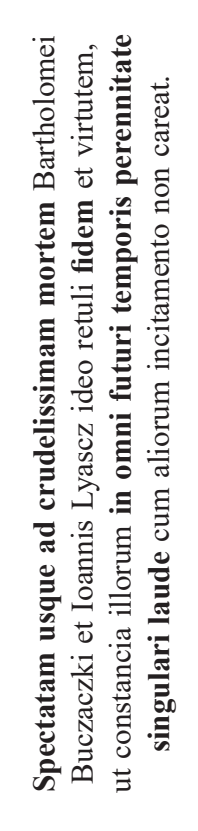 \\
\hline 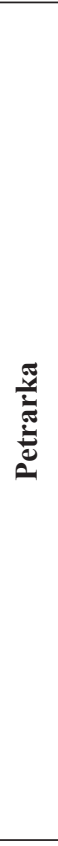 & 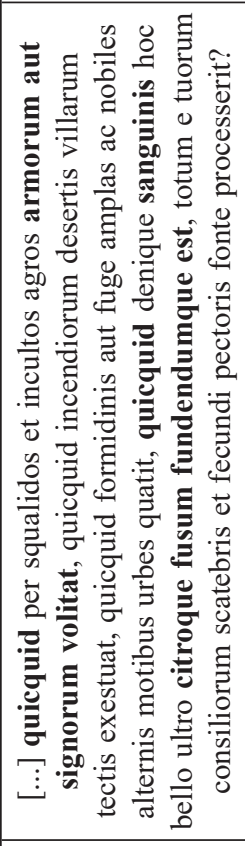 & 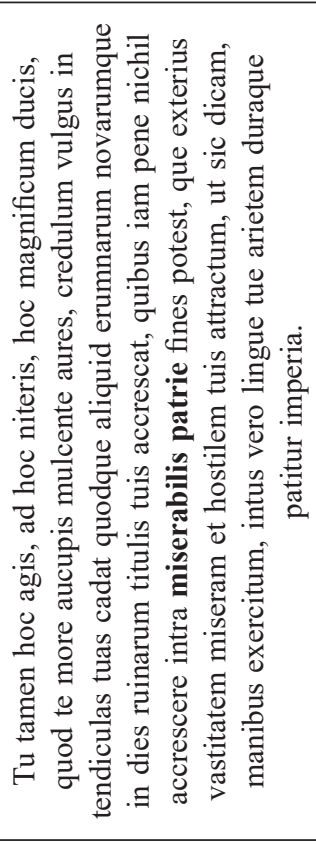 & 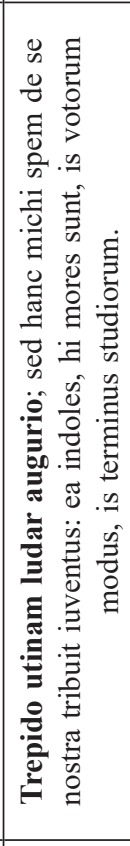 & 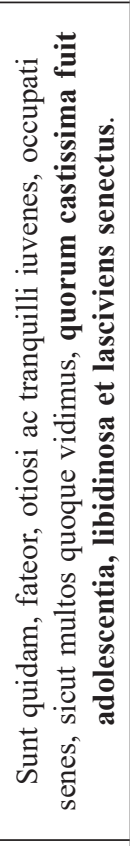 & 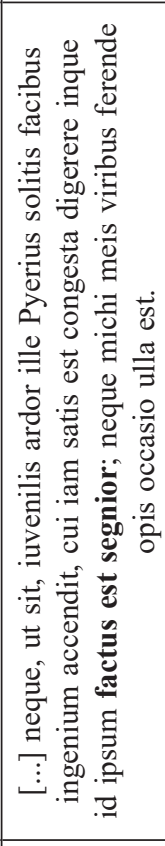 & 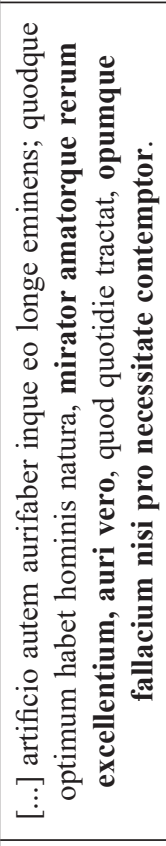 & 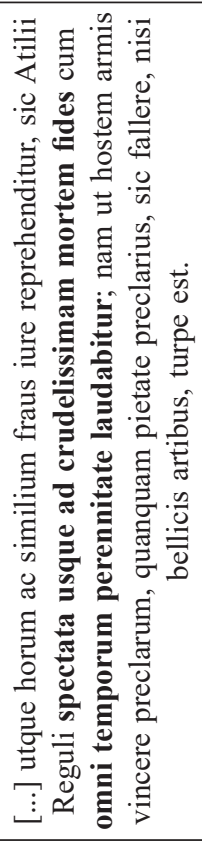 \\
\hline 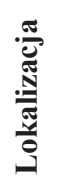 & 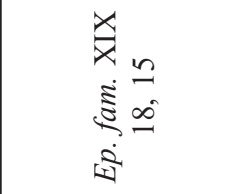 & 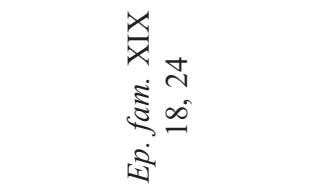 & 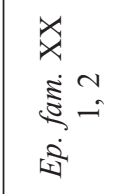 & 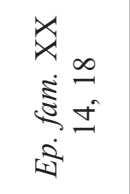 & $\begin{array}{l}\vec{x} \\
x \\
\stackrel{\Sigma}{\Sigma}\end{array}$ & 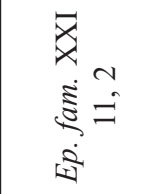 & 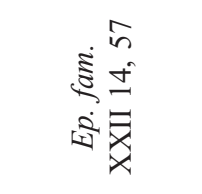 \\
\hline$\dot{\grave{\lambda}}$ & $\dot{8}$ & 80 & $\dot{b}$ & oे & $\dot{R}$ & & i \\
\hline
\end{tabular}




\begin{tabular}{|c|c|c|c|c|c|c|c|}
\hline 忽 & 1 & 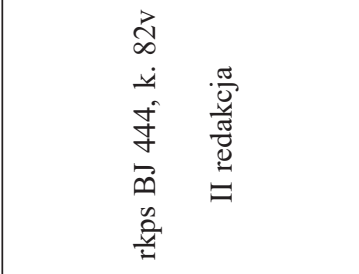 & 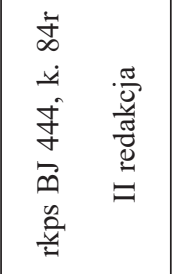 & $\begin{array}{l}\vec{b} \\
\infty \\
\ddot{1} \\
\dot{0} \\
\vec{y} \\
\vec{m} \\
0 \\
\frac{0}{4}\end{array}$ & 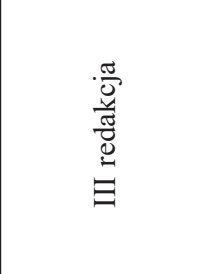 & 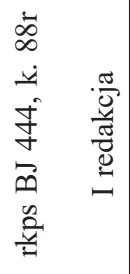 & 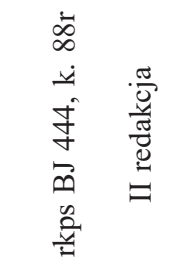 \\
\hline 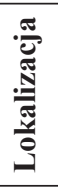 & $\begin{array}{l}\stackrel{\vec{X}}{\circ} \\
\stackrel{\Xi}{ \pm}\end{array}$ & $\begin{array}{l}\hat{0} \\
\vdots \\
5 \\
\vdots \\
\vdots\end{array}$ & 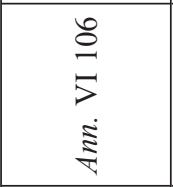 & $\begin{array}{l}\text { 齐 } \\
\text { 芒 } \\
\text { त }\end{array}$ & $\begin{array}{l}\text { సे } \\
> \\
5 \\
\text { हे }\end{array}$ & 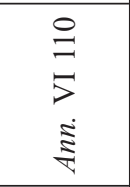 & $\begin{array}{l}\hat{0} \\
5 \\
\text { s. } \\
\hat{\Xi}\end{array}$ \\
\hline 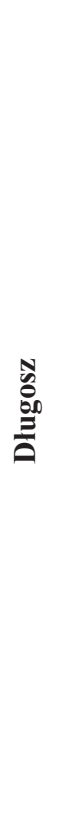 & 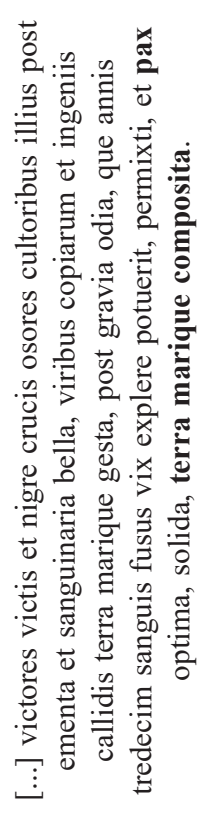 & 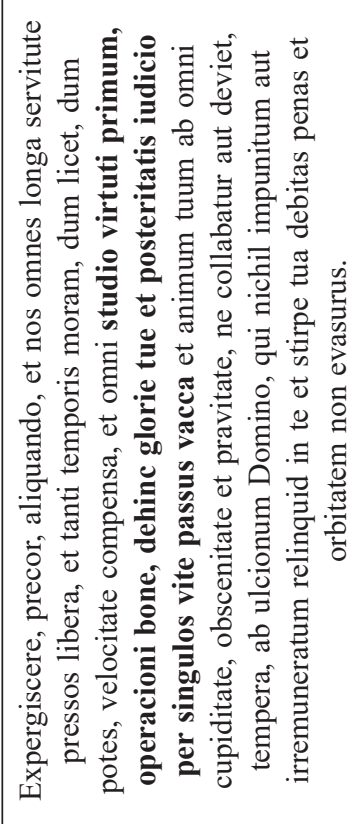 & 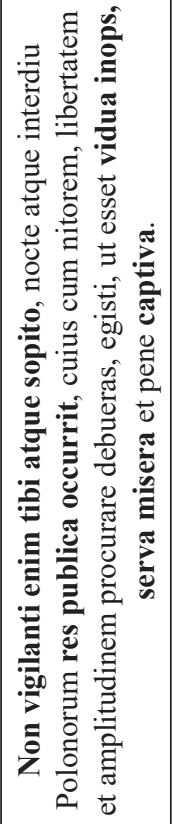 & 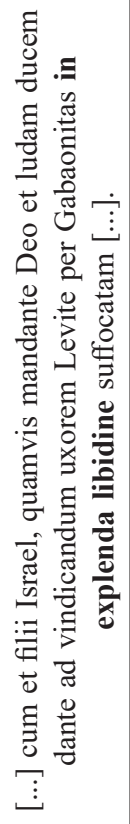 & 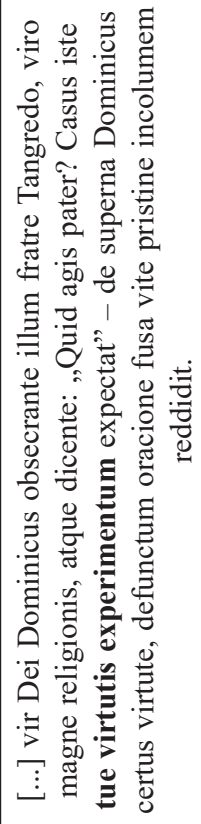 & 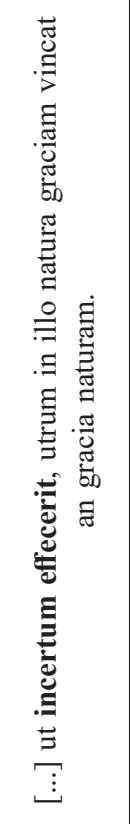 & 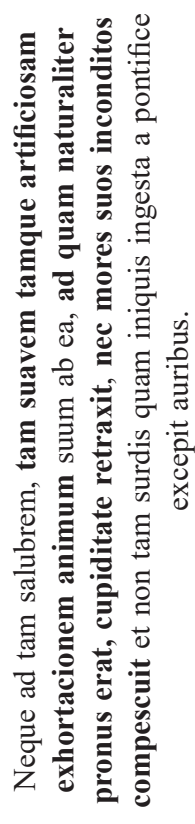 \\
\hline 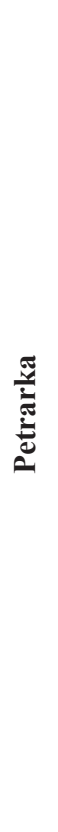 & 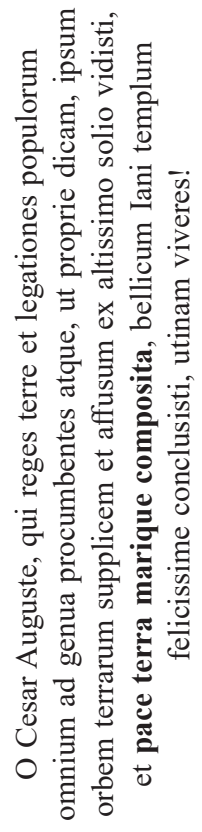 & 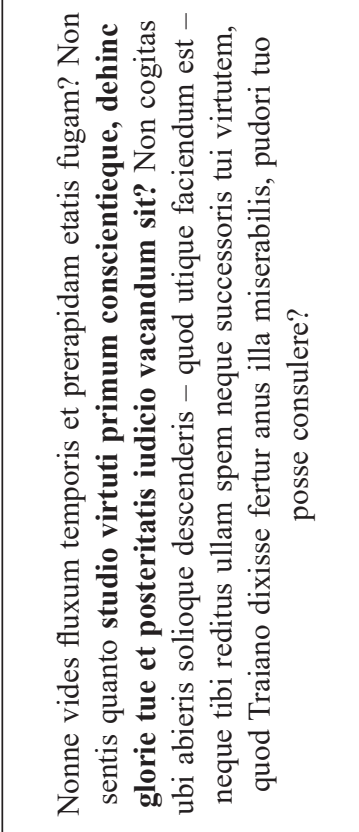 & 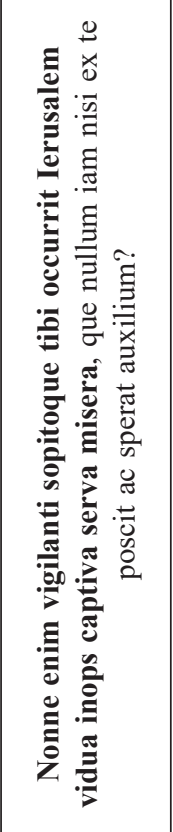 & 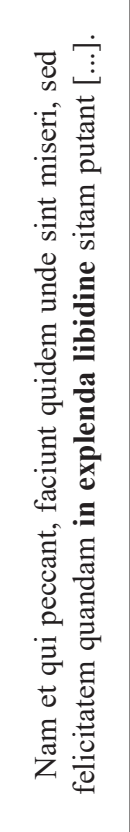 & 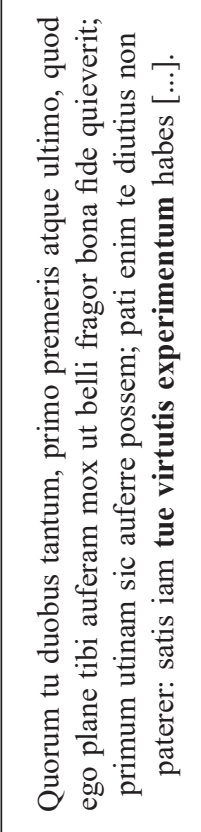 & 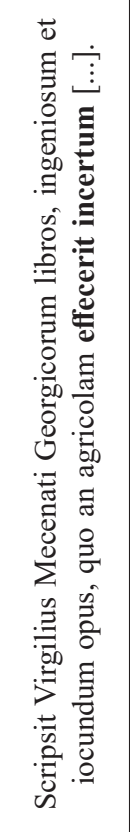 & 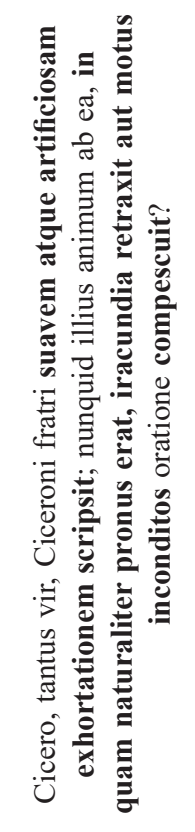 \\
\hline 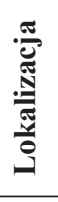 & $\underbrace{0}$ & 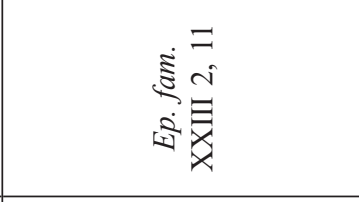 & 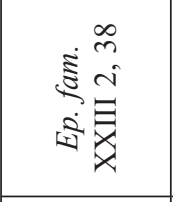 & 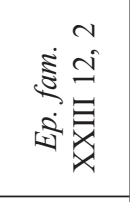 & 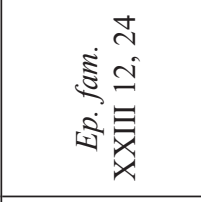 & 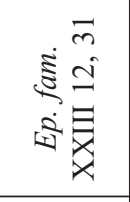 & 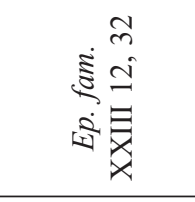 \\
\hline$\dot{\Xi}$ & $\stackrel{\sim}{\sim}$ & $\stackrel{+}{i}$ & $i$ & $\stackrel{0}{\circ}$ & $\stackrel{\Sigma}{\therefore}$ & $\stackrel{\infty}{\triangleright}$ & $\stackrel{2}{2}$ \\
\hline
\end{tabular}




\begin{tabular}{|c|c|c|c|c|c|}
\hline ס & 1 & 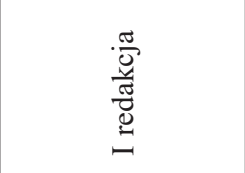 & 1 & 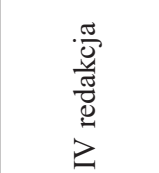 & 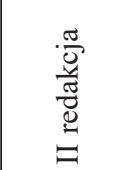 \\
\hline 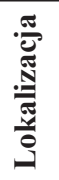 & $\begin{array}{l}n \\
0 \\
\dot{x} \\
\vdots \\
\dot{\Sigma}\end{array}$ & $\begin{array}{l}\beth \\
> \\
\vdots \\
\vdots\end{array}$ & 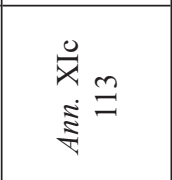 & $\begin{array}{l}3 \\
9 \\
9 \\
\vdots \\
\vdots\end{array}$ & 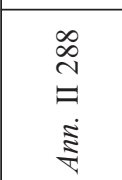 \\
\hline 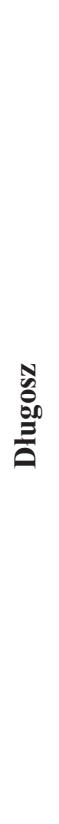 & 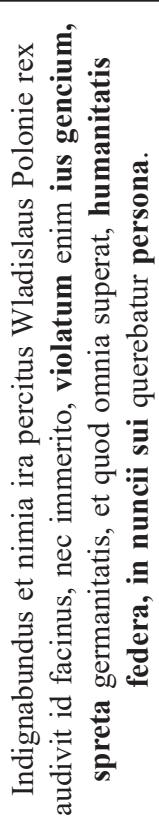 & 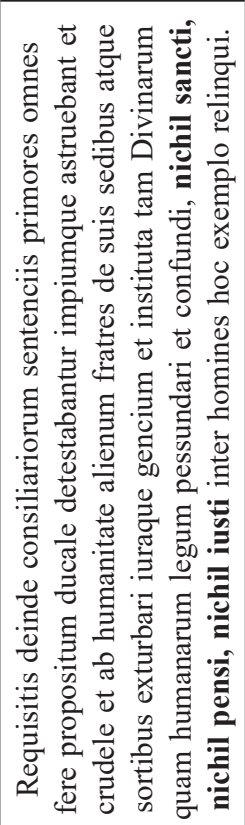 & 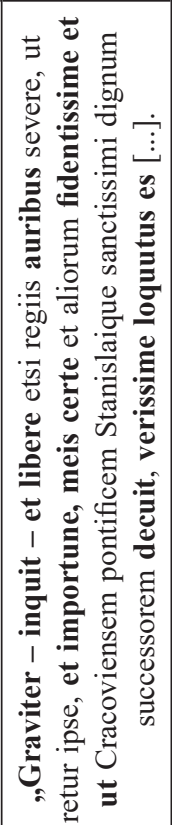 & 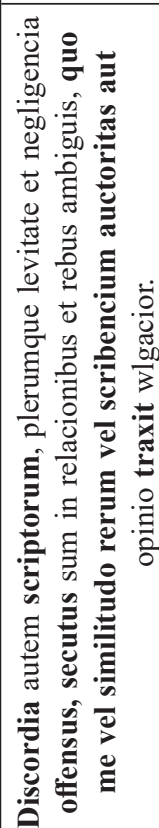 & 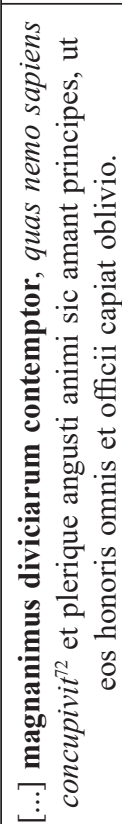 \\
\hline 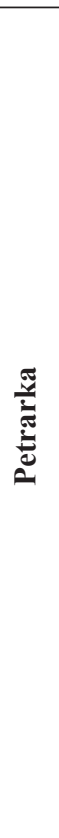 & 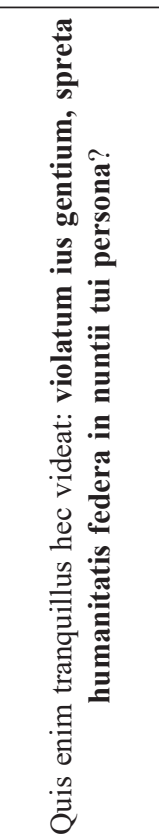 & 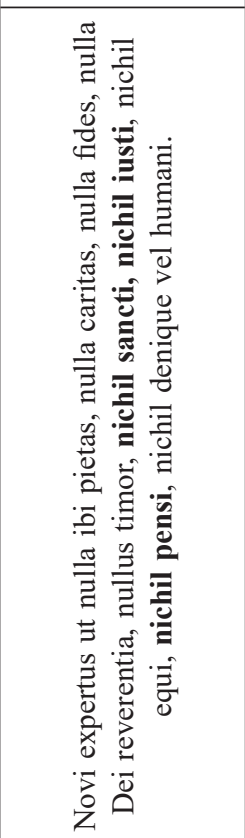 & 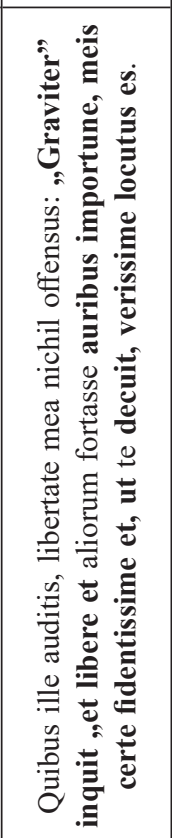 & 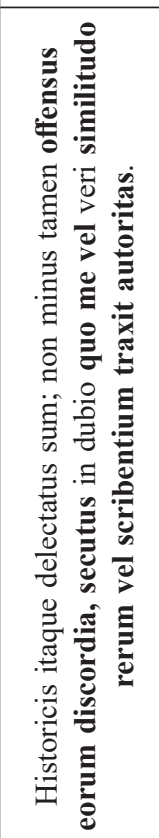 & 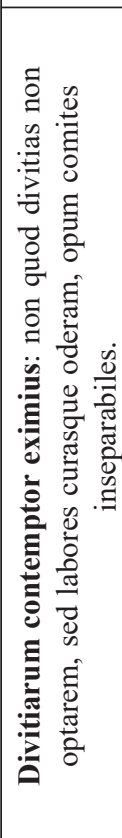 \\
\hline 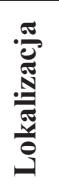 & 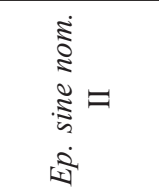 & 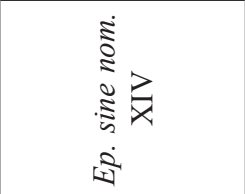 & 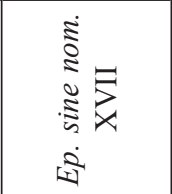 & $\begin{array}{l}n \\
\dot{\vec{m}} \\
2\end{array}$ & $\begin{array}{l}= \\
\dot{\tilde{c}} \\
e^{\circ}\end{array}$ \\
\hline$\dot{\Delta}$ & $\dot{\infty}$ & $\dot{\infty}$ & $\infty_{\infty}^{i}$ & $\dot{\infty}$ & $\dot{\infty}$ \\
\hline
\end{tabular}

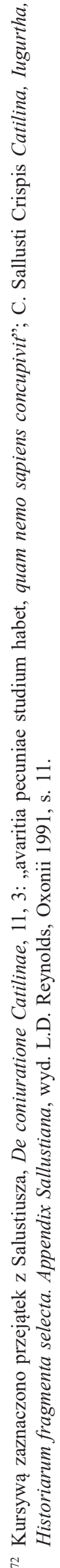




\title{
New argument in the dispute about Dlugosz: textual excerpts from Petrarch in the Annals of Jan Długosz
}

\begin{abstract}
Summary: The study shows textual excerpts from the works by Petrarch (1304-1374) (particularly De remediis utriusque fortunae, De viris illustribus, Epistolae familiares, Epistolae sine nomine and Posteritati) in the Annals of Jan Długosz (1415-1480), the most important chronicler of medieval Poland. A computer-assisted comparative analysis, part of the linguistic project "Długosz 2.0", introduces n-grams - literal quotations - and presents the methodology of drawing them from compared corpora. It comprises the idea of the program as well as rules and restrictions of acquiring the study material. Subsequently, the author conducts a quantitative and qualitative analysis of the gathered word-sequences, by which he tries to define when Długosz read Petrarch's works (at the beginning of his works on the Annals or in its final stage), displays the topics he was most interested in (characteristics, military issues and narrative models), and presents how he used excerpts in his chronicle (directly in the narration or as the narrator's commentaries). The analysis also shows the humanistic nature of the usage of those quotations and how they enrich the style of the Annals. Moreover, the study focuses on two medieval manuscripts from Jagiellonian Library in Cracow: MS BJ 444 (with Epistolae familiares) and MS BJ 721 (with De remediis utriusque fortunae), and investigates their maniculae and glossae. In his summary, the author proposes new arguments on the "catalogue hypothesis" (excerpts from a single text in different redactions of the chronicle, a number of mnemonic signs and the multidimensional development of quotations), which could answer the question of how Długosz worked with his literary sources? Finally, the author lists every commune textual excerpt (more than eighty word-sequences in total) as the material for further studies.
\end{abstract}

Nota o autorze: Zdzisław Koczarski, mgr, pracownik i doktorant w grancie „Długosz 2.0” Pracowni Łaciny Średniowiecznej Instytutu Języka Polskiego Polskiej Akademii Nauk w Krakowie, gdzie przygotowuje rozprawę doktorską poświęconą partykułom modalnym w Rocznikach Jana Długosza.

Author: Zdzisław Koczarski, M.A., employee and postgraduate in the grant "Długosz 2.0" at the Department of Medieval Latin of the Institute of Polish Language, Polish Academy of Sciences in Cracow, works on PhD thesis on modal particles in Jan Długosz' Annals.

Instytut Języka Polskiego

Polska Akademia Nauk

al. Mickiewicza 31

31-120 Kraków

e-mail: zdzislaw.koczarski@ijp.pan.pl

\section{Bibliografia}

\section{Źródla}

Ioannis Dlugossii Annales seu Cronicae incliti Regni Poloniae, ks. I-XII, Varsaviae-Cracoviae 1964-2005

Petrarka F., De remediis utriusque fortunae, De viris illustribus, Epistolae familiares z cyfrowego repozytorium Corpus Corporum, $<\mathrm{http}: / / \mathrm{www} . \mathrm{mlat}$. uzh.ch/MLS/>; Epistolae sine nomine, Posteritati z cyfrowego repozytorium Interbooks, <http://www.interbooks.eu//poesia/trecento/francescopetrarca.html>

\section{Opracowania}

Catalogus codicum manuscriptorum medii aevi Latinorum qui in Bibliotheca Jagellonica Cracoviae asservantur, t. 2, 3, 5, red. M. Kowalczyk i in., Wratislaviae 1982-1993

Contieri N., La fortuna del Petrarca in Polonia nei secoli XIV e XV, „Annali dell'Istituto Universitario Orientale. Sezione Slava", 4, 1961, s. 139-166

Dlugossiana. Studia historyczne w pięćsetlecie śmierci Jana Dlugosza, cz. 2: Referaty i komunikaty wygloszone na międzynarodowej sesji w Krakowie w dniach 23 i 24 października 1980 r., red. S. Gawęda, Warszawa-Kraków 1985

Domański J., Scholastyka i poczatki humanizmu w myśli polskiej XV wieku, Warszawa 2011

Kowalczyk M., Jagiellońskie rękopisy Liwiusza z marginaliami Jana Dtugosza, „Eos”, 58, 1969/1970, nr 2, s. $219-230$ 
Kowalczyk M., Z badań nad życiem i biblioteka Mikołaja Kozłowskiego, „Biuletyn Biblioteki Jagiellońskiej”, 22, 1972, s. $19-28$

Madyda W., Wzory klasyczne w „Historii Polski” Dlugosza, „Eos”, 49, 1957/1958, nr 2, s. 177-201

Mann N., The Manuscripts of Petrarch's „De remediis”. A Checklist, „Italia Medioevale e Umanistica”, 14, 1971, s. $57-90$

Olszaniec W., Jan Dlugosz lettore del „De mulieribus claris”, w: Boccaccio e la nuova ars narrandi, red. W. Olszaniec, P. Salwa, Warszawa 2015, s. 137-149

Petrarch. A Critical Guide to Complete Works, red. V. Kirkham, A. Maggi, Chicago 2009

Rajfura H., Jana Dlugosza list dedykacyjny do „Katalogu arcybiskupów gnieźnieńskich”, „Odrodzenie i Reformacja w Polsce", 62, 2018, s. 111-138

Rajfura H., Warsztat pisarski Jana Dlugosza w świetle „Żywotu św. Stanisława”, St. Źródł., 56, 2018, s. 33-75

Rogalanka A., Przedmowa Dlugosza do „Dziejów Polski”, Rocz. Hist., 19, 1950, s. 68-98

Schnayder J., Salustiuszowe echa w „Historii Polski” Dlugosza, „Eos”, 46, 1952, nr 2, s. 141-160

Semkowicz-Zarembina W., Elementy humanistyczne redakcji „Annalium” Jana Dlugosza, w: Mediaevalia. W 50 rocznice pracy naukowej Jana Dabrowskiego, red. J. Garbacik, Warszawa 1961, s. 244-251

Semkowicz-Zarembina W., Powstanie i dzieje autografu „, Annalium” Jana Dlugosza, Kraków 1953

Sinko T., De Dlugosii praefatione „Historiae Polonorum”, w: Studia z dziejów kultury polskiej, red. H. Barycz, J. Hulewicz, Warszawa 1949, s. 105-145

Zarębski I., Humanistyczna lektura Dtugosza: Antonio Panormita Beccadelli (w sporze o Dlugosza argument nowy), „Biuletyn Biblioteki Jagiellońskiej”, 17, 1965, s. 5-21

Zarębski I., Dlugosz a Poggio Bracciolini (w sporze o Dlugosza argument), „Rocznik Naukowo-Dydaktyczny. Historia. Wyższa Szkoła Pedagogiczna w Krakowie”, 14, 1962, s. 29-44

Zarębski I., Problemy wczesnego Odrodzenia w Polsce: Grzegorz z Sanoka - Boccaccio - Dlugosz, „Odrodzenie i Reformacja w Polsce", 2, 1957, s. 5-52 